\title{
ISOLAMENTO, IDENTIFICAÇÃO E CARACTERIZAÇÃO GENÉTICA DE BACTÉRIAS ENDOFÍTICAS DE PORTA-ENXERTOS DE CITROS
}

\section{WELINGTON LUIZ DE ARAUJO \\ Biólogo}

Orientador: Prof. Dr. João Lúcio de Azevedo

Dissertação apresentada à Escola
Superior de Agricultura "Luiz de
Queiroz", da Universidade de São
Paulo, para obtenção do título de
Mestre em Agronomia, área de
concentração: con Genética
Melhoramento de Plantas

PIRACICABA

Estado de São Paulo - Brasil

Julho - 1996 


\section{USP/ESALU \\ DEPARTAMENTO DE OENETICA BIBLIOTECA}

\section{Dados Internacionais de Catalogação na Publicação (CIP) DIVISĀo DE BIBLIOTECA E DOCUMENTAÇÃO - Campus "Luiz de Queiroz"/USP}

Araujo, Welington Luiz de

Isolamento, identificação e caracterização genética de bactérias endofiticas de porta-enxertos de citros / Welington Luiz de Araujo. - - Piracicaba, 1996.

99 p. : il.

Dissertação (mestrado) -- Escola Superior de Agricultura Luiz de Queiroz, 1996.

Bibliografia.

1. Bactéria endofitica 2. Fruta citrica 3. Marcador molecular 4. Porta-enxerto 5. Variação genética I. Título 


\section{ISOLAMENTO, IDENTIFICAÇÃO E CARACTERIZAÇÃO GENÉTICA DE BACTÉRIAS ENDOFITICAS DE PORTA-ENXERTOS DE CITROS}

Welington Luiz de Araujo

Aprovado em: 07.07.1996

Comissão Julgadora:

Prof. Dr. João Lúcio de Azevedo

ESALQ/USP

Profa. Dra. Halha O. Saridakis

UEL/Londrina

Prof. Dr. José Odair Pereira

UFAM/Manaus

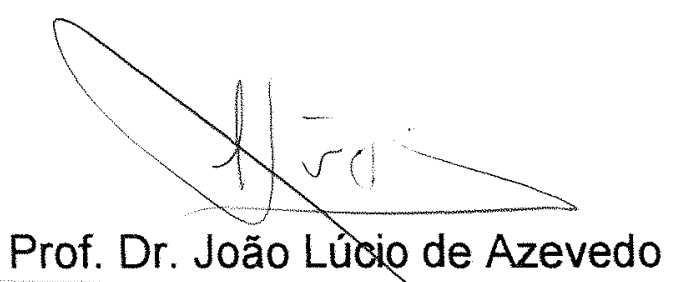

Orientador 
A Denise e fessika pela amor,

compreensão e apoio

\footnotetext{
A minha familia pelo amor, incentiva e exemplo
} 
"Foi no nosso tempo que a Biologia perdeu a sua inocência multissecular. Dantes ela contava os segmentos dos artrópodes e as inflorescências das fanerogâmicas, descrevia a anatomia e a fisiologia dos corpos, mas estava inocente da maldade dos espiritos.

Mas, um dia, começou a entrar na pele dos seres vivos, a estudar a química das sensações e a dissecar as moléculas da hereditariedade. Descobriu que desde 0 primeiro átomo de hidrogênio até a mente humana, toda a universal diversidade é trespassada por um fio de unidade elementar. Através dele, foi penetrando no mundo do pensamento, e acabou por se ver envolvida nos problemas sociais, filosóficos, religiosos e político dos homens.

De inocente, a Biologia passou a ser considerada responsável por boa parte dos caminhos que trilha a nossa civilização." 


\section{AGRADECIMENTOS}

- Ao Departamento de Genética da Escola Superior de Agricultura "Luiz de Queiroz" - ESALQ/USP, e em especial agradeço ao Prof. Dr. João Lúcio de Azevedo pela oportunidade e orientação durante a realização deste trabalho.

- À Prof. Dr. Halha O. Saridakis do Depto. de Patologia/CCB/UEL pela paciência, amizade e orientação durante a identificação dos isolados.

- À Profa. Dra. Aline Ap. Pizzirani-Kleiner, pela amizade e facilidade concedidas.

- À Profa. Dra. Luzia D. Paccola-Meirelles, pela amizade e orientação durante a minha formação científica.

- Ao amigo Marcelo Afonso Vallim pela amizade, incentivo e constantes orientações e sugestões.

- À Profa. Dra. Maria Helena P. Fungaro pelas sugestões, bem como à Profa. Dra. Maria Lúcia Carneiro Viera pelas valiosas sugestões e pelas facilidades concedidas em seu laboratório durante as reações de RAPD.

- Ao Dr. Luciano Nass pelo auxílio durante as análises estatísticas.

- Ao colega José O. Pereira pelas valiosas sugestões durante a execução deste trabalho. 
- Ao Centro de Citricultura Sylvio Moreira/IAC pela concessão do material vegetal utilizado, e ao seu pesquisador Carlos I. Aguilar-Vildoso pela amizade, sugestões e incentivo durante este trabalho.

- À Wilma Pandolfi pelas correções gramaticais.

- Ao Walter Maccheroni pela correção do summary.

- À Denise Hurtado pelas sugestões, e principalmente pela paciência, amor e compreensão.

- Aos meus pais, Terezinha M. de Araujo e Luiz V. de Araújo, aos meus irmãos Diogo, Sérgio e Donizete e à minha princesinha Jessika, pelo carinho, atenção e incentivo.

- Aos amigos de casa, em especial: Ricardo Yara, pela agradável convivência e sugestões.

- Aos colegas do laboratório, em especial à Margarete Nadalini, Renata Pascon, Marisa Queiroz, Alexandre de Souza, João Pamphile, Gilda Santos, lara Fino, Joelma e Gislaine pela alegre convivência.

- Aos colegas Rainério Meirelles, Rogério da Costa, Ângela Célis e André Lima, pela amizade e dificuldades ultrapassadas juntos durante 0 curso.

- Às amigas Regina Poli, Luciana Ribeiro e Chirlei Glienke pela amizade, apoio e principalmente por me suportarem durante este período.

- Aos funcionários do Depto. de Genética da ESALQ/USP, em especial: José Antonio, Carmen, Beth, Silvana, Léia, Neusa, Berdã e Fernando pelo apoio. 
- À CAPES pela concessão de bolsa de estudos.

- À todos os professores que contribuiram para minha formação cientifica, e às demais pessoas que direta ou indiretamente auxiliaram na execução deste trabalho.

Muito Obrigado 


\section{ÍNDICE}

AGRADECIMENTOS

página

LISTA DE TABELAS

LISTA DE FIGURAS

RESUMO

SUMMARY

1. INTRODUÇÃO

2. REVISÄO DA LITERATURA

2.1. Microrganismos Endofiticos

2.1.1. Conceitos gerais

2.1.2. Isolamento de endófitos

2.1.3. Ocorrência e localização de endófitos

2.1.4. Ecologia da associação endófitos/hospedeiro

2.1.5. Importância dos endófitos para o controle biológico

2.1.6. Utilização biotecnológica de microrganismos endofíticos

2.2. Bacterioses em Citros

2.2.1. Cancro cítrico

2.2.1.1. Sintomas

2.2.1.2. Controle

2.2.1.3. Disseminação

2.2.2. Clorose variegada dos citros (CVC) …………........................ 14

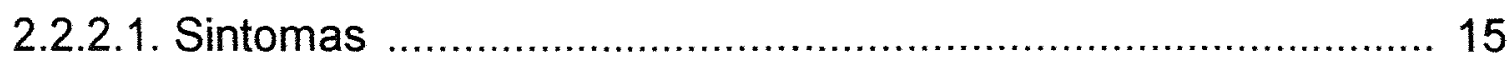

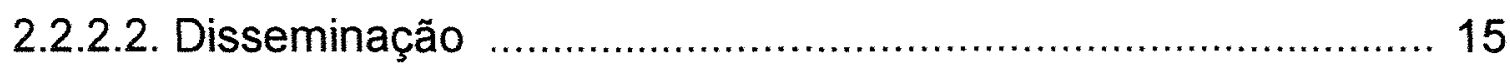

2.3. Caracterizacão Molecular 16

2.3.1. Reação em cadeia da Polimerase - PCR (Polymerase

Chain Reaction) 
2.3.2. Amplificação ao acaso de DNA polimórfico-RAPD (Random Amplified Polimorphic DNA) ......................................... 20

2.3.2.1. Condições e características do RAPD .................................. 20

2.3.2.2. Aplicações da técnica de RAPD .......................................... 23

2.3.2.3. Utilização de RAPD em estudos bacteriológicos ..................... 24

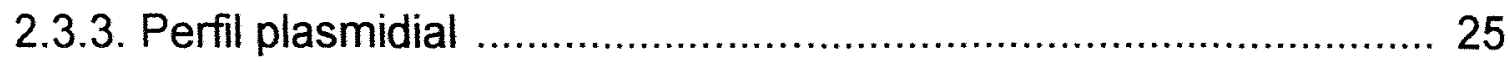

2.3.3.1. Ocorrência de plasmídios em bactérias fitopatogênicas .......... 26

2.3.3.2. Aplicações da determinação do perfil plasmidial ...................... 27

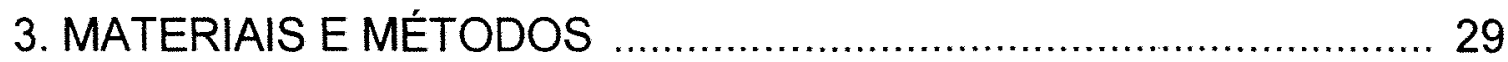

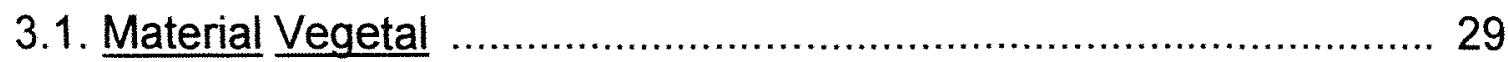

3.1.1. Local de Coleta das amostras ........................................... 29

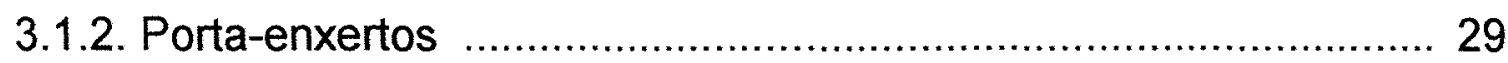

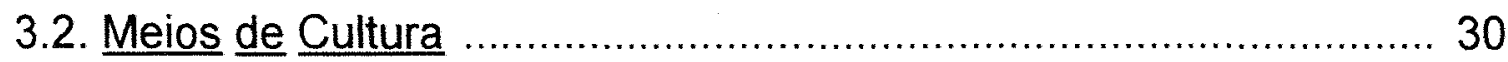

3.2.1. Meio TSA - Tryptic Soy Agar ………………......................... 30

3.2.2. Meio LB - Luria e Bertani …………...................................... 30

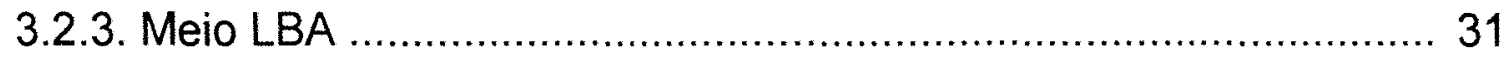

3.2.4. Meio NA - Nutriente ágar ......................................................... 31

3.2.5. Meio Aveia ................................................................. 31

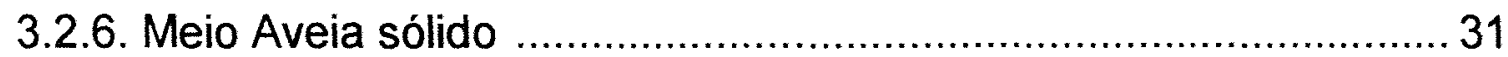

3.2.7. Meio EPM (Toledo et al.,1982) ………................................. 32

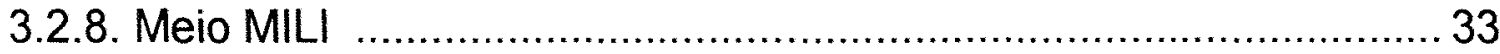

3.2.9. Meio Citrato de Simmons …….................................................. 33

3.2.10. Meio básico para açúcares .................................................... 34

3.2.11. Meio para oxidação-fermentação da glicose (O/F) .................. 34

3.2.12. Meio para verificação de atividade amilolítica ........................... 34

3.2.13. Meio para verificação de atividade gelatinásica ....................... 34

3.2.14. Meio para deteç̧ão de indol ................................................. 35

3.2.15. Meio para redução de Nitrato ............................................... 35

3.2.16. Meio para reação de Voges-Proskauer (VP) ……………....... 35

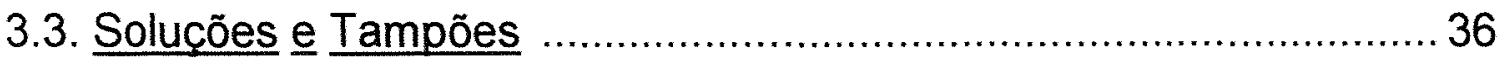

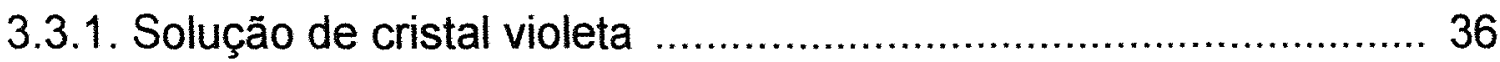

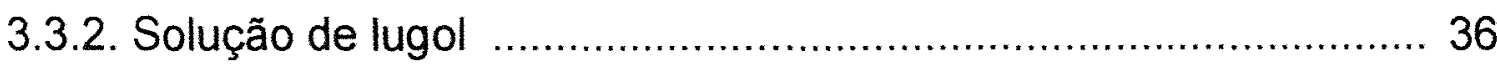

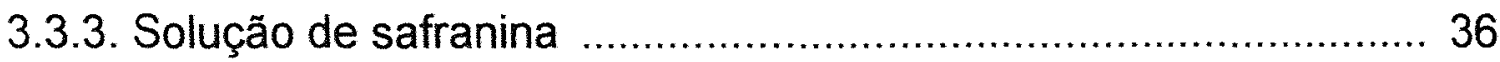


3.3.4. Solução de verde malaquita ................................................ 36

3.3.5. Solução de RNAse ............................................................... 36

3.3.6. Solução de fenol saturado (modificado de Maniatis et al.,

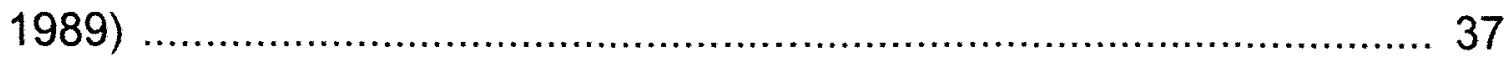

3.3.7. Solução de $\alpha$-naftol ............................................................. 37

3.3.8. Reagentes para o teste do nitrato ...................................... 37

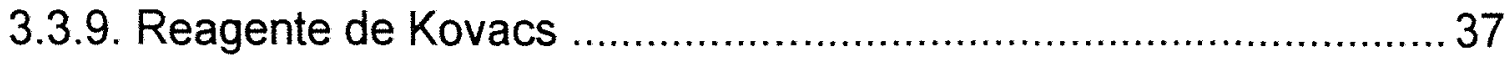

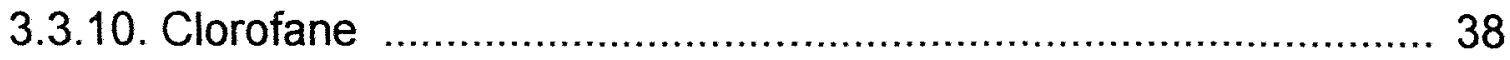

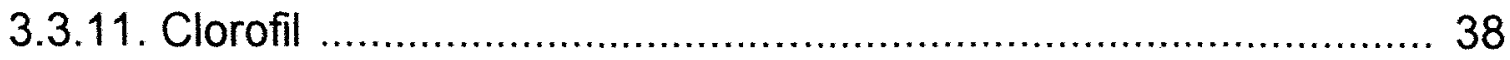

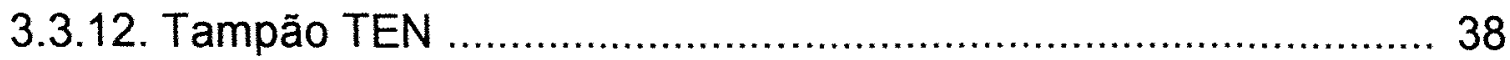

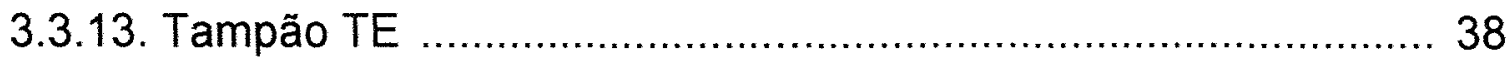

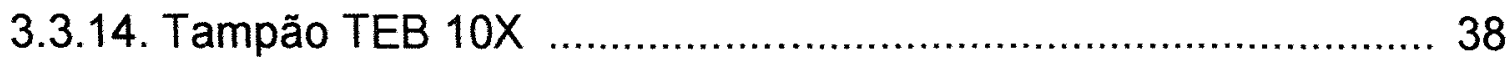

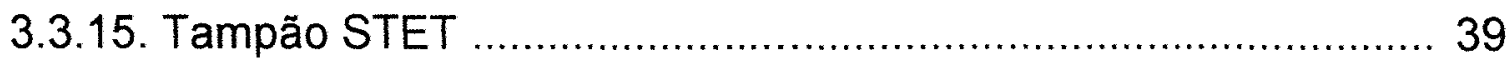

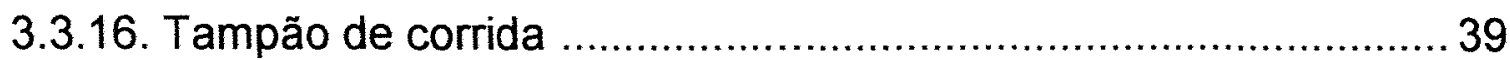

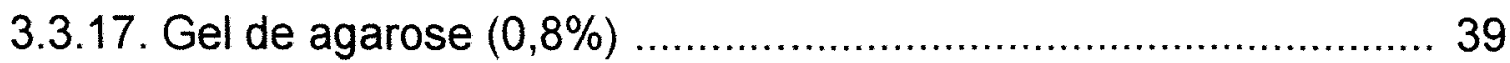

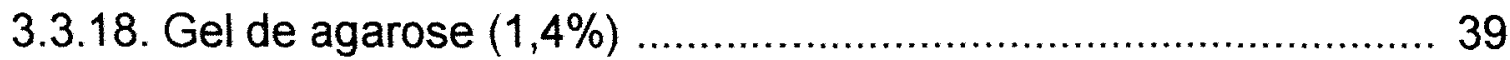

3.3.19. Solução estoque de dNTP's ........................................... 39

3.4. Isolamento de Microrganismos Endofíticos ............................. 40

3.4.1. Desinfecção das folhas e isolamento dos microrganismos ........ 40

3.4.2. Purificação das colônias bacterianas ..................................... 40

3.4.3. Verificação da frequência de isolamento .................................. 41

3.5. Identificacão das bactérias isoladas ....................................4 41

3.5.1. Verificação da morfologia ................................................... 41

3.5.1.1. Colônia bacteriana .......................................................... 41

3.5.1.2. Célula bacteriana .......................................................... 41

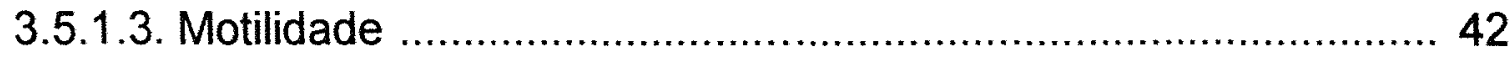

3.5.2. Coloração de Gram ...................................................... 42

3.5.3. Coloração de Wirtz (coloração para esporos) ........................ 42

3.5.4. Identificação bioquímica ..................................................... 43

3.5.4.1. Identificação presuntiva de bastonetes gram negativos ........... 43

3.5.4.1.1. EPM (Ácido e gás de glicose, urease, $\mathrm{H}_{2} \mathrm{~S}, \mathrm{~L}$ triptofano desaminase) ............................................................. 43

3.5.4.1.2. MILI (motilidade, indol-lisina) ....................................... 43 
3.5.4.1.3. Utilização de citrato ................................................... 44

3.5.4.2. Utilização de diferentes fontes de carbono ............................ 44

3.5.4.3. Teste de oxidação e fermentação da glicose (O/F

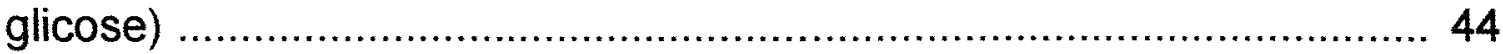

3.5.4.4. Hidrólise do amido ........................................................ 45

3.5.4.5. Hidrólise da gelatina ..................................................... 45

3.5.4.6. Crescimento em diferentes temperaturas ........................... 45

3.5.4.7. Crescimento em $\mathrm{NaCl} 5 \%$............................................... 45

3.5.4.8. Crescimento em diferentes pHs ..................................... 46

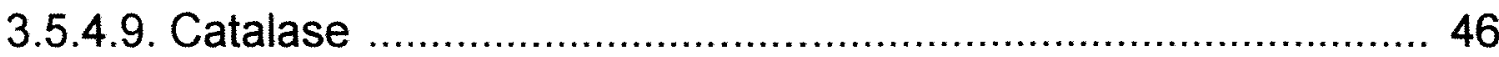

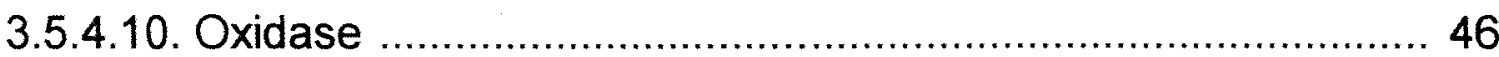

3.5.4.11. Produção de indol ......................................................... 46

3.5.4.12. Redução de nitrato ......................................................... 46

3.5.4.13. Reação de Voges-Proskauer (VP) ................................. 47

3.6. Verificação da interação fungo-bactéria .................................... 47

3.6.1.Isolados fúngicos utilizados ............................................ 47

3.6.2. Obtenção de metabólitos fúngicos …................................... 47

3.6.3. Ação dos metabólitos fúngicos sobre colônias bacterianas

3.6.4. Verificação da estabilidade térmica dos metabólitos fúngicos ............................................................................... 48

3.7. Técnicas moleculares …..................................................... 48

3.7.1. Extração de DNA ............................................................. 48

3.7.1.1. Extração de DNA total genômico ......................................... 48

3.7.1.2. Extração de DNA plasmidial (Del Sal et al., 1988) ................. 49

3.7.1.3. Verificação da integridade do DNA ..................................... 50

3.7.2. Verificação do perfil plasmidial ............................................ 51

3.7.2.1. Perfil plasmidial ............................................................... 51

3.7.2.2. Clivagem do DNA plasmidial .......................................... 51

3.7.3. Análise de polimorfismo gerado por marcadores de RAPD ........ 51

3.7.3.1. Amplificação do DNA genômico .......................................... 51

3.7.3.2. "Primers" selecionados ....................................................... 53

3.7.3.3. Construção de dendrograma ......................................... 53 


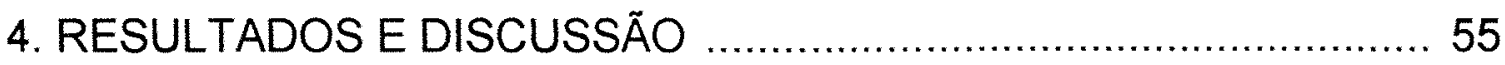

4.1. Isolamento de Bactérias Endofíticas ........................................ 55

4.2. Identificação Bioquímica dos Isolados Bacterianos …................. 58

4.2.1. Bactérias gram positivas ................................................... 59

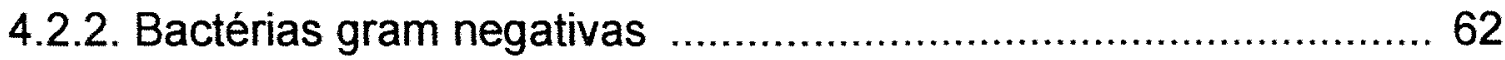

4.3. Acão de Metabólitos Fúngicos Sobre Bactérias Endofiticas .........66 65

4.3.1. Bactérias gram positivas ...................................................... 65

4.3.2. Bactérias gram negativas ............................................. 68

4.3.3. Termoestabilidade dos metabólitos fúngicos .......................... 70

4.4. Variabilidade Genética por RAPD ..................................... 71

4.4.1. Padronização da técnica e escolha dos "primers" .................... 71

4.4.2. Verificação de polimorfismo por RAPD ................................... 73

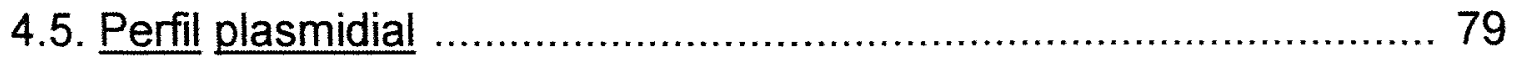

5. CONCLUSÕES ................................................................ 83

6. REFEREANCIAS BIBLIOGRÁFICAS ….................................. 84

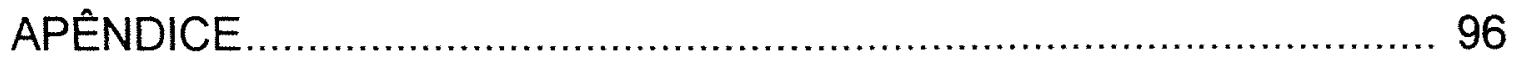




\section{LISTA DE TABELAS}

página

Tabela 3.1 - Relação de porta enxertos de citros utilizados no trabalho

Tabela 3.2 - Relação de enzimas de restrição e respectivas sequências de reconhecimento

Tabela 3.3 - Componentes e respectivas concentrações utilizadas em uma reação de RAPD

Tabela 3.4 - Lista de "primers" selecionados e respectivas sequências de nucleotídeos

Tabela 4.1 - Frequência de isolamento (FI) de bactérias endofíticas de folhas de porta-enxertos de citros

Tabela 4.2 - Distribuição das bactérias gram positivas e gram negativas por porta-enxertos

Tabela 4.3 - Características bioquímicas de bastonetes gram positivos produtores de esporos

Tabela 4.4 - Características bioquímicas de bastonetes gram positivos não esporulados

Tabela 4.5 - Desdobramento em grupos bioquímicos de bastonetes gram positivos

Tabela 4.6 - Características bioquímicas de bastonetes gram negativos isolados de porta-enxertos

Tabela 4.7 - Desdobramento em grupos bioquímicos de bastonetes gram positivos

Tabela 4.8 - Isolados bacterianos identificados e seus respectivos hospedeiros 
Tabela 4.9 - Ação de metabólitos excretados por fungos endofíticos de plantas cítricas em bactérias endofíticas gram positivas 68

Tabela 4.10 - Ação de metabólitos excretados por fungos endofíticos de plantas cítricas sobre bactérias endofiticas gram negativas 70 


\section{LISTA DE FIGURAS}

Figura 2.1 - Ciclos de amplificação de uma sequência alvo de DNA

página via reação em cadeia da DNA polimerase (PCR). Observar a desnaturação do DNA, anelamento dos dois "primers" e a extensão dos "primers" 19

Figura 2.1 - Continuação 20

Figura 2.2 - Amplificação de uma sequência alvo de DNA via reação em cadeia da DNA Polimerase (PCR) com "primer" arbitrário (RAPD). Observar anelamento dos "primers" nas duas fitas complementares do DNA 21

Figura 4.1 - Crescimento de fungos endofíticos a partir de explantes foliares de porta-enxertos de citros, após 4 dias de incubação 56

Figura 4.2 - Aspectos do isolamento de bactérias endofíticas de explantes foliares de porta-enxertos de citros. Observar crescimento de bactérias das bordas dos fragmentos foliares, após 24 (a) e 72 horas (b) de incubação 56

Figura 4.3 - Frequência total de isolamento de bactérias endofíticas de porta enxertos de citros 58

Figura 4.4 - Porcentagem dos grupos bacterianos na população total estudada 66

Figura 4.5 - Aspecto do crescimento bacteriano na presença dos metabólitos fúngicos: a)Bacillus $\mathrm{sp}$. com halo de inibição, devido a ação de metabólitos do isolado $\mathrm{M} 131$ de G. citricarpa; b)E. herbicola com crescimento normal; c)E. herbicola com halo de crescimento estimulado por 
metabólitos produzidos pelo isolado $M 131$ de $G$. citricarpa 69

Figura 4.6 - Padrão de bandas obtidos no ensaio para ajuste na concentração de DNA com os "primers" (b)OPX04; (c)OPX09; (d)OPX14 e (e)OPX10. As concentrações utilizadas foram: 1)5,0 $\mathrm{ng} ; 2) 2,5 \mathrm{ng} ; 3) 10 \mathrm{ng}$. (a)marcador de peso molecular (DNA $\lambda$ clivado com Hind III)

Figura 4.7 - Perfil eletroforético obtido com o "primer" OPX09 dos isolados de E. herbicola [CT05 (1), LC06 (2), LV23 (3), LD32 (4), LV24 (5), LT37 (6), TO47 (7), TS51 (8), TO45 (9)], Alcaligenes sp. [CTO4 (10)], N.I.4 [LC11 (11)], Bacillus spp [LCO9 (12), LT34 (13), CT01 (14), CK20 (15), LD30 (16), LV21 (17), LD28 (18), LC07 (19), LC08 (20), CL14 (21), N.I.1 [CL16 (22) e LD31 (23)], Bacillus spp. [CK 17 (24), TS50 (25), CL13 (26), CK19 (27), LV22 (28), LV26 (29), LT38 (30), TC40 (31), LV25 (32), LV27 (33), LD33 (34)], branco (35), a)Marcador de peso molecular (DNA $\lambda$ clivado com hind III)

Figura 4.8 - Dendrograma obtido a partir de uma matriz de similaridade genética entre os isolados endofíticos de porta-enxertos de citros. Para a construção da matriz, foi utilizado o coeficiente de JACCARD 76

Figura 4.9 - Perfil eletroforético obtido com o "primer" OPE14 dos isolados de E. herbicola [CT05 (1), LCO6 (2), LV23 (3), LD32 (4), LV24 (5), LT37 (6), TO47 (7), TS51 (8), TO45 (9)], Alcaligenes sp. [CTO4 (10)], N.I.4 [LC11 (11)], Bacillus spp [LCO9 (12), LT34 (13), CTO1 (14), CK20 (15), LD30 (16), LV21 (17), LD28 (18), LC07 (19), LC08 (20), CL14 (21), N.I.1 [CL16 (22) e LD31 (23)], Bacillus spp. [CK 17 (24), TS50 (25), CL13 (26), CK19 (27), LV22 (28), LV26 (29), LT38 (30), TC40 (31), LV25 (32), 
LV27 (33), LD33 (34)], branco (35), a)Marcador de peso molecular (DNA $\lambda$ clivado com hind III)

Figura 4.10 - Padrão de bandas plasmidiais não clivadas, obtidas após extração. 1)marcador de peso molecular (DNA de

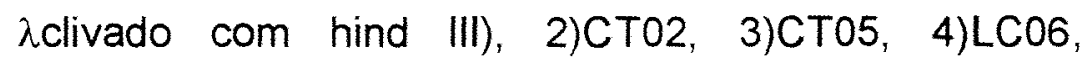
5)CL12, 6)CK18, 7)LV23, 8)LV24, 9)LD32, 10)LT37, 11)TC41, 12)TO45, 13)TO47, 14)TS49, 15)TS51, 16)CT04, 17)LC11, 18)LD29, 19)LT34, 20)TC42; CRM (DNA cromossômico 80

Figura 4.11 - Perfil de bandas obtidos após clivagem de DNA plasmidial. a)DNA plasmidial do isolado CK18 clivado com diferentes enzimas de restrição. 1)marcador de peso molecular (DNA de $\lambda$ clivado com hind III), 2) Hind III, 3)Sau 3Al, 4)Kpn I, 5)Xba 1, 6)Xho I, 7)Not I, 8)Sfi I, 9)Eco RI, 10)DNA plasmidial não clivado; b)DNA plasmidial de diferentes isolados clivados com Not l: 1)LC06, 2)LCK18, 3)LD32, 4)TO47, 5)DNA plasmidial não clivado, 6)marcador de peso molecular (DNA de $\lambda$ clivado com hind III) 


\title{
ISOLAMENTO, IDENTIFICAÇÃO E CARACTERIZAÇÃO GENÉTICA DE BACTÉRIAS ENDOFÍTICAS DE PORTA-ENXERTOS DE CITROS
}

\author{
Autor: Welington Luiz de Araujo \\ Orientador: Prof. Dr. João Lúcio de Azevedo
}

\section{RESUMO}

Endófitos são microrganismos que em pelo menos uma fase do seu ciclo de vida, habitam o interior de tecidos da parte aérea de plantas assintomáticas. Foi realizado um estudo sobre a população bacteriana endofítica de dez porta-enxertos de citros, mantidos no Centro de Citricultura Sylvio Moreira-IAC. Foram isolados de explantes foliares principalmente dois grupos bacterianos: um deles constituído de isolados do gênero Bacillus (incluindo B. pumilus, B. megaterium, B. cereus, B. lentus) e outro, constituído por Erwinia herbicola. Verificou-se que a espécie mais frequente foi $E$. herbicola $(24,45 \%)$; entretanto, se for considerado o gênero, Bacillus foi o mais frequente $(50,98 \%)$. A presença em maior frequência de isolados deste gênero se deve provavelmente à resistência de seus endósporos ao tratamento para desinfecção superficial dos tecidos foliares, pois resultados obtidos da interação destas bactérias com o fungo endofitico Guignardia citricarpa e análise via marcadores de RAPD, sugerem que Bacillus spp. fazem parte da população epifítica destas plantas, e eventualmente podem entrar no hospedeiro por meio de aberturas como estômatos e/ou ferimentos, sendo nestes casos considerados como endófitos facultativos. Já, E. herbicola apresenta uma associação simbiótica com o fungo endofítico estudado, o qual deve favorecer a colonização bacteriana no hospedeiro. Esta característica aliada ao fato de que esta bactéria, frequentemente isolada de plantas como endófita, apresentou pequena divergência genética, detectada por marcadores de RAPD e perfil plasmidial, sugerem que deva ocorrer uma intima interação entre o fungo G. citricarpa, a bactéria endofítica e a planta hospedeira, a qual deve manter reduzida a variabilidade genética neste grupo bacteriano. A constatação do estado endofítico de $E$. herbicola, juntamente com esta interação com a planta, mostra a possibilidade de se utilizar esta espécie para a introdução de características de interesse em porta-enxertos de citros. 


\title{
ISOLATION, IDENTIFICATION AND GENETIC CHARACTERIZATION OF ENDOPHYTIC BACTERIA FROM ROOTSTOCKS CITRUS.
}

\author{
Author: Welington Luiz de Araujo \\ Adviser: Prof. Dr. João Lúcio de Azevedo
}

\section{SUMMARY}

Endophytes are microorganisms which live inside aerial tissue of assyntomatic plants, during at least one phase of their life cycles. Ten rootstocks citrus were used. In order to get insights about their endophytic bacterial population. Endophytic bacteria were isolated from foliar tissue and could be divided in two main groups. The first group was formed by Bacillus (including B. megaterium, B. cereus, B. pumilus, B. lentus), and a second group was formed by Enwinia herbicola. The frequencies of bacteria from group one and two were $50,98 \%$ and $24,45 \%$, respectively. The high frequency of the genus Bacillus found in the bacterial population is probably due to the endospore resistance to superficial desinfection of the leaf tissue. This observation was based on the interaction showed by these bacterias with the endophytic fungi Guignardia citricarpa and RAPD analysis, suggesting that Bacillus spp. is part of the epiphytic population of this plants. Eventually these epiphytic bacteria it may penetrate inside the host by stomats or injuries and in this case they could be considerered facultative endophytes. However, E. herbicola shows a simbiotic association with the studied endophytic fungi, which favours the bacterial colonization of the host. This finding, plus the low genetic divergence of several isolates from this bacteria, detected by RAPD and plasmidial profile, suggested that $E$. herbicola occurs in a close interaction with the fungus. The endophytic state of $E$. herbicola, added to its interaction with the host plants, suggests the possibility of using this species for the introduction of characteristics of interest in rootstocks citrus. 


\section{INTRODUÇÃO}

Endófitos são microrganismos que, em pelo menos uma fase do seu ciclo de vida, habitam o interior de tecidos da parte aérea de plantas assintomáticas. Devido ao grau de interação entre o endófito e a planta hospedeira, estes microrganismos podem ser classificados como endófitos facultativos ou endófitos verdadeiros. Embora estes microrganismos possam ser confundidos com patógenos latentes, estudos anteriores verificaram que os microrganismos endofíticos apresentam importante interação com a planta hospedeira, pois podem produzir compostos que diminuem a herbivoria, podem conferir resistência à patógenos, ou ainda podem aumentar o poder de germinação de sementes infectadas. Em contrapartida, estes endófitos podem receber proteção e nutrientes do hospedeiro.

O estudo desta interação possibilitará a utilização destes endófitos em programas de melhoramento de espécies vegetais de interesse, pois estes microrganismos endofíticos podem ser manipulados geneticamente e reintroduzidos na planta hospedeira, conferindo novas caracteristicas a essa planta, como resistência a patógenos e a pragas, produção de proteínas e vitaminas.

Atualmente, pouco se conhece a respeito dos aspectos ecológicos, fisiológicos e genéticos envolvidos nesta interação, entretanto, já se conhece a importância dos endófitos para a planta e o seu potencial biotecnológico. Por esses motivos, os estudos sobre estes microrganismos se intensificaram a partir da década de 80 , visando o entendimento desta associação.

Dentro deste contexto, para o entendimento desta interação, se faz necessário o isolamento dos microrganismos endofiticos do interior 
de plantas de interesse, enquanto que para a compreensão dos aspectos genéticos envolvidos, inicialmente são necessários estudos para se detectar variabilidade genética nos isolados de interesse.

O RAPD ("Random Amplified Polymorphic DNA"), baseado na técnica da PCR ("Polymerase Chain Reaction"), é um importante método para se detectar, rápida e eficientemente variabilidade genética entre indivíduos semelhantes, além de apresentar inúmeras vantagens sobre outras técnicas moleculares como o RFLP ("Restriction Fragment Lenght Polymorphisms"), e a PCR. Outra forma de se verificar variabilidade genética em bactérias, é por meio da análise do conteúdo de DNA plasmidial presente em diferentes isolados, pois estas estruturas extracromossômicas frequentemente são associadas à especificidade dos isolados ao seu habitat de origem.

Dentro deste contexto, o presente trabalho teve por objetivos:

- Isolar e identificar bactérias endofíticas de 10 porta-enxertos utilizados na citricultura.

- Caracterizar geneticamente estes isolados por meio de marcadores de RAPD e perfil plasmidial.

- Verificar a ocorrência de especificidade dos genótipos bacterianos aos genótipos das plantas hospedeiras.

- Verificar o efeito dos fungos isolados endofiticamente de citros, Guignardia citricarpa e Colletotrichum gloeosporioides sobre os isolados bacterianos. 


\section{REVISÃO DA LITERATURA}

\subsection{Microrganismos Endofiticos}

\subsubsection{Conceitos gerais}

A interação entre plantas e microrganismos é relatada há muito tempo, porém, com excessão da associação entre fungos micorrízicos e plantas e organismos diazotróficos da rizosfera, acreditavase que esta interação levava a formação de lesões nos tecidos vegetais, as quais poderiam causar a morte da planta. Entretanto, vem sendo registrada a presença de microrganismos no interior de tecidos vegetais assintomáticos abrindo novas perspectivas para o estudo da interação planta/microrganismos. Especial atenção vem sendo dada à possibilidade da utilização destes microrganismos como vetores para a introdução de características desejadas em plantas de interesse.

De acordo com Bary $(1866)^{1}$ citado por Stone (1986), a microbiota micótica do interior de tecidos vegetais assintomáticos ou não, incluindo fungos que apresentam interações antagônicas, neutras ou simbiônticas com a planta, é denominada de endófita. Entretanto, com a realização de inúmeros trabalhos e a verificação da importância destes microrganismos do interior de tecidos vegetais, este conceito de endófito foi alterado e atualmente denomina-se endófitos todos os microrganismos capazes de colonizar, em alguma fase do seu ciclo vida, tecidos vegetais

\footnotetext{
${ }^{I}$ BARY, A. de. Morphologie und physiologie der Pilze. Flechten, und Myxomyceten. vol. II. Hofmeister's Handbook of Physiological Botany, Leipzig, 1866.
} 
da parte aérea, sem causar danos à planta (Carroll, 1986², modificado por Petrini, 1991), porém, neste conceito são excluídos os fungos micorrízicos e microrganismos não micorrizicos presentes no interior de tecidos radiculares.

A identificação de um microrganismo como endófito deve ser vista com cautela, pois, segundo Sinclair (1991) a colonização de plantas por microrganismos endofíticos pode ser semelhante, em muitos casos, à infecções latentes por fitopatógenos. Além disso, esta interação entre endófitos e seus hospedeiros pode ser alterada por meio de mudanças ambientais e microbiológicas drásticas que ativam o crescimento e a patogenicidade de microrganismos endofíticos ou presentes no filoplano (Sanford, 1948; Samish et al., 1963; Meneley \& Stanghellini, 1975), mostrando dessa forma a necessidade de se compreender melhor esta interação. Dentro deste contexto, Bashan et al. (1982) verificaram que isolados de Xanthomonas campestris pv. vesicatoria são capazes de se multiplicar endofiticamente em folhas de pimenta e, ocasionalmente, sob determinadas condições ambientais, causam sintomas nestes hospedeiros. Segundo esses autores, esta bactéria pode infectar sementes de plantas sadias sendo dessa forma, disseminada causando posteriormente sintomas em plântulas originadas destas sementes.

De acordo com Misaghi \& Donndelinger (1990), a intima relação entre bactérias endofíticas e seus hospedeiros envolveu processos coevolutivos podendo, inclusive, influenciar mecanismos fisiológicos da planta. Com o objetivo de se entender esta interação, inúmeros trabalhos foram desenvolvidos, e várias espécies de fungos $\mathrm{e}$ bactérias foram isoladas de tecidos vegetais sadios (Sanford, 1948; Samish et al., 1963; Bugbee et al., 1975; Jacobs et al., 1985; Misaghi \& Donndelinger, 1990; Boddey et al., 1991; Döbereiner, 1992; Fisher et al., 1992; Tör et al.;1992; Pereira et al.; 1993; Fisher et al., 1995; entre outros). Até o momento, pouco se sabe sobre os aspectos genéticos, ecológicos e fisiológicos da interação planta/endófitos, mas, o

${ }^{2}$ CARROLL, G.C. The biology of endophytism in plants with particular eference to woody perennials. In: FOKKEMA, N.J.; HEUVEL, J. Van den, ed. Microbiology of phyllosphere. London: Cambridge University Press, 1986. p.205-222. 
entendimento desta interação poderá permitir a utilização prática destes microrganismos com fins econômicos em agricultura, indústria farmacêutica e biotecnologia.

\subsubsection{Isolamento de endófitos.}

O estudo de endófitos inicia-se com o isolamento destes do interior da planta. Durante este processo cuidados devem ser tomados para se evitar o crescimento de microrganismos da microbiota epifítica da planta. Estes cuidados incluem a lavagem das superfícies foliares com agentes desinfetantes (Schulz et al., 1993; Pereira et al., 1993, Dong et al., 1994; Fisher et al., 1995), retirada asséptica da seiva da planta por esmagamento (James et al., 1994), ou coleta asséptica de tecidos internos do vegetal desejado (Jacobs et al., 1985). De acordo com Pereira et al. (1993), os processos e os tempos necessários para desinfecção, dependem basicamente da espessura da cutícula e da epiderme dos tecidos do hospedeiro.

Entretanto, mesmo após a desinfecção dos tecidos vegetais, um pequeno número de esporos e fragmentos de hifas podem sobreviver, e neste caso, fungos contaminantes comuns da superfície, como Penicillium spp., podem se desenvolver (Fisher et al., 1992). De acordo com estes autores, outro problema durante 0 isolamento de microrganismos endofíticos é a presença de fungos de crescimento rápido, como Altemaria altemata, que podem mascarar o crescimento de outros endófitos.

\subsubsection{Ocorrência e localização de endófitos.}

A presença de endófitos já foi constatada em inúmeras espécies vegetais de interesse econômico, entre elas citros (Childs et al., 1965; Glienke, 1995; Araujo \& Azevedo, 1995), beterraba açucareira (Bugbee et al., 1975; Jacobs et al., 1985), algodão (Misaghi \& Donndelinger, 1990), cana-de-açúcar (Boddey et al., 1991; Döbereiner, 
1992; Dong et al., 1994; Reis et al., 1994), trigo (Ruppel et al., 1992), inhame (Tör et al., 1992), milho (Fisher et al., 1992; Souza, 1996), banana e estilosantes (Pereira et al., 1993). Com a finalidade de se verificar a localização e a forma de infecção destes microrganismos endofíticos nestas plantas hospedeiras, trabalhos foram desenvolvidos utilizando métodos citoquímicos e microscopia eletrônica, possibilitando melhor compreensão deste processo infeccioso (Ruppel et al., 1992).

A entrada de microrganismos em seus hospedeiros pode ocorrer de forma ativa, por meio de força mecânica ou com auxílio de enzimas que degradam a parede da célula hospedeira, atráves de vetores como insetos, por aberturas naturais como estômatos, hidatódios e ferimentos. De acordo com Ruppel et al. (1992), a presença de células de Pantoea agglomerans (sin. Enterobacter agglomerans) próximas aos estômatos de folhas de trigo sugerem que esta seja uma porta de entrada desta bactéria diazotrófica.

Entretanto, Paula et al. (1991) verificaram que a penetração de Acetobacter diazotrophicus em seu hospedeiro está associada com a presença do fungo micorrizico vesículo-arbuscular Glomus clarum, pois, foi constatado que a infecção desta bactéria em seu hospedeiro é dependente da presença deste fungo. Foi verificado por microscopia eletrônica a presença de células bacterianas no interior dos esporos deste fungo micorrizico, mostrando a intima interação desta bactéria com $G$. clarum e a planta hospedeira. Segundo Jacobs et al. (1985), bactérias também podem penetrar no hospedeiro por meio de ferimentos ocorridos durante a emergência de raízes secundárias. Esta hipótese é sustentada pela observação frequente de bactérias no interior de raízes, próximas a estas regiōes.

Após a entrada do endófito no hospedeiro, estes microrganismos podem ocupar regiões específicas da planta, como constatado por Fisher et al. (1992) em milho (Zea mays L.). Estes autores observaram que os fungos colonizam mais intensamente regiões apicais da planta, enquanto as bactérias se localizam, preferencialmente próximo à base do caule deste hospedeiro. Concordando com este resultado, 
Fisher et al. (1995) verificaram que as folhas apresentam um número maior de fungos endofíticos que raízes e caules de Dryas octopetala L. (Rosaceae). Já, Döbereiner (1992) verificou que três novas espécies de bactérias diazotróficas são obrigatórias ou predominantemente endófitas, ou seja, não ocorrem no solo e atingem números mais elevados no caule e nas folhas de cana-de-açúcar.

Apesar de estar bem estabelecida a presença de endófitos no interior de diferentes orgãos da planta, o tipo de interação endófito/planta pode depender da localização destes microrganismos no tecido hospedeiro. Estes microrganismos endofíticos podem permanecer nos espaços intercelulares do mesófilo foliar e do córtex radicular ou nos vasos xilemáticos (Ruppel et al., 1992), ou ainda estarem presentes no interior das células destes tecidos (Jacobs et al., 1985; Tör et al., 1992) mantendo uma interação intracelular mais íntima com o hospedeiro, semelhante à observada para fungos patogênicos biotróficos (Viret \& Petrini, 1994).

Misaghi \& Donndelinger (1990) introduziram Erwinia sp. em sementes germinadas de algodão, e posteriormente reisolaram esta bactéria endofítica de todos os tecidos sadios deste hospedeiro, mostrando a capacidade de disseminação sistemática do endófito na planta. Esta disseminação também foi observada por Ruppel et al. (1992) em trigo (Triticum aestivum L.), após inoculação de $P$. agglomerans em raiz e partes aérea desse cereal.

Observam-se constantemente endófitos em vasos xilemáticos de hospedeiros (Jacobs et al., 1985; Ruppel et al, 1992), sugerindo que estas estruturas sejam o caminho mais frequente para a disseminação dos endófitos no interior da planta, podendo também, através destes vasos, alcançarem as sementes e dai serem disseminados juntamente com estas estruturas.

Dentro deste contexto, observou-se que Acremonium coenophialum é disseminado endofiticamente com sementes de Festuca arundinacea (Knoch et al., 1993), enquanto que $A$. diazotrophicus endófita de cana-de-açúcar pode ser disseminada pelo fungo micorrízico G. clarum 
e também por meio de reprodução vegetativa da planta hospedeira (Dobereiner, 1992).

\subsubsection{Ecologia da associação endófitos/hospedeiro}

Como já discutido anteriormente, a íntima relação entre endófitos e plantas hospedeiras depende basicamente da localização do microrganismo na planta e de mecanismos fisiológicos compativeis entre o hospedeiro e o endófito, os quais resultam de processos coevolutivos. Dentro deste contexto, Childs et al. (1965) sugerem que a capacidade do fungo Physoderma citri em crescer no interior de tecidos assintomáticos de várias espécies de citros se deve a existência de um delicado balanço entre os requisitos nutricionais deste endófito e da planta hospedeira.

De acordo com Howard et al. (1992) a planta pode produzir alcalóides em resposta à infecção do microrganismo endofítico. Estes alcalóides também podem ser produzidos pelos fungos endofiticos durante o processo infeccioso, levando a uma interação mutualística com a planta hospedeira, pois, estas substâncias poderiam resultar numa diminuição da herbivoria sobre a planta (Knoch et al., 1993).

Como citado acima, a disseminação do endófito produtor de alcalóides via sementes pode protegê-la de predação. Esta interação mutualistica foi verificada por Knoch et al. (1993) em sementes de $F$. arundinacea, normalmente predadas por Pogomyrmex rugosus e $P$. occidentalis. Nesse trabalho, esses autores verificaram que sementes infectadas com 0 endófito $A$. coenophialum eram predadas em menor frequência que sementes não infectadas. Em contraposição, muitas sementes colhidas por $P$. rugosus são descartadas e nesse caso constatou-se que sementes infectadas são mais constantemente eliminadas em locais que aumentam a frequência de germinação destas sementes, quando comparado com sementes mantidas próximas às plantas mãe. Dessa forma, os autores verificaram que a infecção endofitica de $A$. coenophialum em sementes de $F$. arundinacea diminui a predação e promove a disseminação das sementes infectadas. 
Segundo Clay et al. (1993), larvas de Spodoptera frugiperda são capazes de discriminar entre espécies de plantas e entre indivíduos infectados ou não pelo endófito Acremonium spp. Estes autores sugerem que o microrganismo endofítico aumenta o vigor do hospedeiro e confere resistência da planta infectada à herbivoria, tornando-a mais competitiva em relação às plantas não infectadas. Esta melhor adaptação da planta colonizada pelo endófito à presença do predador, pode aumentar a frequência de plantas infectadas pelo endófito na população.

Os endófitos também podem, segundo Ranta et al. (1994), suprimir o crescimento do fungo Gremmeniella abietina, patógeno de pinheiro escocês. Nesse trabalho foi ainda verificado que estes endófitos são sensiveis ao níquel ( $\mathrm{Ni}$ ) presente em ambientes poluídos, possibilitando o crescimento do patógeno nestas condições, e mostrando a importância do endófito para a planta hospedeira.

Outra forma de interação entre plantas e endófitos é observada entre bactérias diazotróficas e plantas hospedeiras. Nessa associação a bactéria fixa uma grande quantidade de $N_{2}$, que é parcialmente excretado para o meio intercelular da planta hospedeira, a qual poderá então utilizar este nitrogênio orgânico.

A bactéria diazotrófica Acetobacter diazotrophicus foi isolada endofiticamente de colmos e folhas de cana-de-açúcar (Döbereiner, 1992; Dong et al., 1994; Reis et al., 1994; James et al., 1994) e juntamente com duas outras bactérias fixadoras de $\mathrm{N}_{2}$, (Herbaspinilum seropedicae e $\mathrm{H}$. rubrisubalbicans) também encontradas neste ambiente, mostram a possibilidade de se estender esta interação a outras plantas de interesse agrícola, gerando um aumento na produção sem elevação dos custos com adubação nitrogenada.

Entretando, nem sempre a presença de endófitos pode resultar em benefícios econômicos, pois, a presença de bactérias do gênero Pseudomonas, Bacillus, Erwinia e Flavobacterium no interior de tecidos sadios de beterraba açucareira (Beta vulgaris L.), pode estar relacionada com a hidrólise de sacarose deste hospedeiro, após períodos 
de estocagem, resultando em prejuízo econômico para os produtores (Bugbee et al. 1975).

Como já discutido anteriormente, as bactérias endofíticas devido a processos coevolutivos, apresentam íntima relação com seus hospedeiros e podem influenciar na fisiologia da planta (Misaghi \& Donndelinger, 1990). Esta coevolução, provavelmente, levou à seleção de genes nos microrganismos endofíticos, os quais codificam proteínas que aumentam o vigor ("fitness") da associação, bem como genes da planta regulados pela presença do endófito, que também beneficiam a associação. Portanto, além de processos fisiológicos, inúmeros mecanismos genéticos podem estar associados nesta interação planta/endófitos.

\subsubsection{Importância dos endófitos para o controle biológico}

A capacidade dos endófitos em viverem no interior de tecidos vegetais sem causar danos ao hospedeiro, aliada ao fato de poderem ser transmitidos via sementes, torna estes microrganismos candidatos em potencial para o controle biológico de pragas e/ou de patógenos de plantas, vetores de novas características para as plantas hospedeiras.

Völksch et al. (1992) realizaram um estudo qualitativo de populações bacterianas presentes em lesões de folhas de soja, e verificaram que bactérias do gênero Enwinia apresentam a capacidade de sintetizar metabólitos que inibem o desenvolvimento de Pseudomonas syringae pv. glycinea, responsável por essas lesões. O estudo da interação destas e de outras bactérias isoladas deste local, pode permitir a utilização dessas bactérias antagônicas contra $P$. S. pv. glycinea responsável pela queima bacteriana em soja.

Entretanto, nem sempre é necessário o isolamento de bactérias antagônicas de lesões, pois, foi verificado que linhagens de Fusarium oxysporum isolados endofiticamente de raiz de tomate produzem um metabólito secundário tóxico para o nematóide Meloidogyne incognita e diminui o crescimento de Phytophthora cactorum, Pythium 
ultimum e Rhyzoctonia solani "in vitro". Estes metabólitos foram utilizados em bioensaios com alface e em campo também foi verificado o biocontrole de $M$. incognita (Hallmann \& Sikora, 1996).

De acordo com Johnson \& Whitney (1994), hifas e extratos de hifas de fungos endofiticos de Picea mariana apresentam variada atividade inseticida contra larvas de Choristoneura fumiferana Clem. Dentro deste contexto, foi verificado que a presença do fungo endofítico Acremonium spp. em Festuca spp. aumenta a susceptibilidade de larvas de Popillia japonica ao nematóide entomopatogênico Heterorhabditis bacteriophora (Grewal et al., 1995). Segundo esses autores o aumento da susceptibilidade da praga ao nematóide ocorre devido à produção de metabólitos secundários pelo endófito que inibe o desenvolvimento das larvas tornando-as menos resistentes. Esta constatação mostra a possibilidade da utilização desses microrganismos para a produção de compostos com ação inseticida ou fungicida, ou a utilização direta destes endófitos visando este biocontrole.

\subsubsection{Utilização biotecnológica de microrganismos endofiticos}

O entendimento dos mecanismos genéticos da associação entre plantas e microrganismos endófitos poderá contribuir em programas de melhoramento vegetal que envolvam microganismos endofíticos manipulados geneticamente. Após esta manipulaçào genética, esses microganismos poderiam ser reintroduzidos no hospedeiro, conferindo novas características como resistência a pragas, produção de proteínas e vitaminas às plantas de interesse.

O primeiro relato da utilização de um microrganismo endofítico manipulado geneticamente foi realizado por Fahey (1988), o qual utilizou a bactéria Clavibacter xily subsp. cynodontis com o gene da delta endotoxina de $B$. thuringiensis para o controle da broca do colmo de milho. Posteriormente, inúmeros trabalhos foram realizados para se verificar a ação desta bactéria transformada em plantas de milho. Tester (1992) verificou que o endófito alterado geneticamente influenciava as 
propriedades químicas e físicas da planta, porém, não havia diferença significativa no grau de decomposição no solo entre plantas não inoculadas ou inoculadas com o transformante ou o não transformante. De acordo com este autor, $C$. $x$. subsp. cynodontis não sobrevive naturalmente fora da planta hospedeira, sendo, por esse motivo um modelo interessante para se realizar estudos desse tipo.

Este gene de $B$. thuringiensis também foi utilizado para transformar uma linhagem de Bradyrhizobium que induz a nodulação de Cajanus cajan (Nambiar et al., 1990). Foi verificado que estes transformantes se mantiveram estáveis e que o gene de interesse se expressou, tornando a planta resistente às larvas de Rivelia angulata.

Fungos endofiticos também estão sendo ensaiados como vetores para a introdução de características novas em plantas de interesse. Murray et al. (1992) obtiveram em alta frequência transformantes do fungo endofítico Acremonium, resistentes à higromicina, utilizando o plasmídio pAN7-1 em sua forma linear e circular. Esses autores também descreveram a transformação desse fungo com o gene da $\beta$-glucuronidase, e constataram, "in vitro" e "in vivo" após reintrodução do endófito na planta hospedeira, a expressão desse gene.

Estes trabalhos mostram a possibilidade de se manipular geneticamente um microrganismo endofítico e reintroduzi-lo na planta hospedeira, determinando novas características a essas plantas. Entretanto, mais estudos devem ser realizados para se verificar o impacto destes microrganismos no ambiente, ou verificar a possibilidade destes organismos transferirem estes genes para outras bactérias, as quais poderiam causar danos ao ambiente.

\subsection{Bacterioses em Citros}

\subsubsection{Cancro cítrico}

O cancro cítrico é uma das mais importantes bacterioses de citros. Esta doença é causada pela bactéria gram negativa Xanthomonas 
campestris pv. citri. Segundo Namekata (1991), a origem desta doença é tão remota que deve coincidir com a origem dos citros, entretanto, o mais antigo material com sintomas de cancro cítrico conhecido, data do ano de 1827.

De acordo com Namekata (1991) são conhecidos quatro tipos de cancrose causadas por diferentes estirpes ou patótipos de $X$. c. pv. citri. A cancrose " $A$ ", ou asiática, foi a primeira a ser constatada, afeta todas as espécies e variedades de Citrus e está disseminada por quase todos os continentes. A cancrose "B", ou sul-americana, afeta apenas a laranja azeda, enquanto que a cancrose " $C$ " atinge apenas o limão galego e foi constatada no estado de São Paulo na década de 60 e a Cancrose dos Viveiros, constatada em 1984 na Flórida (EUA), ataca apenas plantas jovens de viveiros.

\subsubsection{Sintomas}

Os sintomas da doença, segundo Namekata (1991), são observados nas faces superior e inferior de folhas, ramos e frutos das plantas afetadas. Estes sintomas, inicialmente, são caracterizados por um halo amarelo em torno de pontuações de cor castanha clara que evolui para lesões corticosas de coloração castanha. A medida que a lesão envelhece, uma faixa de aspecto aquoso junto à lesão corticosa torna-se escura, quase preta. Entretanto, pequenas variações nesta sintomatologia podem ser observadas, dependendo do cultivar ou variedade afetada do patótipo ou estirpe bacteriana, ou ainda, das condições ambientais.

De acordo com Dutta \& Gibbs (1991), significante produção de etileno foi verificada em folhas de citrumelo "Swingle" (Poncirus trifoliata $X$ Citrus paradisi) inoculadas com $X$. c. pv. citri. Segundo estes autores, esta sintese de etileno pode ser uma forma de defesa da planta, visando a abscisão das folhas infectadas pelo patógeno. 


\subsubsection{Controle}

Embora inúmeros métodos de controle do cancro cítrico sejam descritos na literatura, a erradicação de ramos, plantas afetadas ou próximas ao foco da doença ainda é o método mais eficiente de controle da doença (Namekata, 1991), pois segundo Leite (1990) e Leite \& Mohan (1990) X. c. pv. citri não sobrevive por longo período no solo em associação com plantas não hospedeiras, nem tão pouco em restos da planta.

\subsubsection{Disseminação}

A disseminação do cancro cítrico entre plantas de um mesmo pomar ocorre com auxílio da chuva, principalmente acompanhada de ventos fortes. Determinados tratos culturais também podem auxiliar na disseminação da doença (Namekata, 1991). Portanto, o diagnóstico precoce da doença e cuidados durante o trato cultural evitam a disseminação do cancro cítrico no pomar e também em regiões próximas.

\subsubsection{Clorose variegada dos citros (CVC)}

A clorose variegada dos citros ou "amarelinho" foi detectada em 1987 em pomares de Minas Gerais e São Paulo e vem se alastrando para os estados de Goiás, Rio de Janeiro, Paraná, Santa Catarina, Rio Grande do Sul e Argentina, onde é conhecida como pecosita.

Inicialmente, imaginava-se que a CVC era causada por Spiroplasma citri, agente causal do "greening", mas, observações por meio de microscopia eletrônica indicaram grandes quantidades de bactérias no interior do xilema de plantas infectadas (Rosseti et al., 1990), enquanto que $S$. citri afeta o floema. Segundo estes autores, estas bactérias do xilema são semelhantes à bactéria gram negativa Xyllela fastidiosa, que causa a doença de Pierce em videiras, escaldadura da ameixeira e a "phony peach" em pessegueiros. Anteriormente já se havia verificado 
infecção cruzada em citros utilizando $X$. fastidiosa de videiras com a doença de Pierce (Brlansky et al., 1984). Portanto, este e outros resultados confirmaram as suspeitas existentes de que $X$. fastidiosa é o agente causal do CVC.

Segundo Hopkins (1989) inúmeros isolados de $X$. fastidiosa podem viver no xilema da planta assintomática, mas quando o hospedeiro encontra-se estressado, principalmente por fatores ambientais, os sintomas podem se desenvolver. Por essa característica, o autor sugere que esta bactéria seja um patógeno fraco e oportunista.

\subsubsection{Sintomas}

De acordo com Rosseti (1991) os sintomas do CVC se assemelham a sintomas de deficiência de zinco e potássio e toxicidade a boro. A clorose variegada das folhas mais desenvolvidas é observada inicialmente na parte mediana e superior da copa, mas, em casos severos da doença pode tomar toda a copa. Os frutos podem tornar-se pequenos e endurecidos, ou seja, imprestáveis para o comércio.

\subsubsection{Disseminação}

Brlansky et al. (1984), verificaram por meio de microscopia eletrônica que este patógeno pode ser transmitido por Oncometopia nigricans Walker. Sabe-se ainda, que as Xyllela são facilmente transmitidas por cigarrinhas da família Cicadelídeos as quais ocorrem abundantemente em pomares citrícolas (Rossetti, 1991) ou por meio de enxertia.

Portanto, para se evitar a disseminação da doença deve se tomar medidas básicas como eliminação do vetor, poda dos ramos afetados e a utilização de mudas provenientes de pomares sem CVC. 


\subsection{Caracterizacão Molecular}

A existência de variabilidade é o princípio básico para estudos genéticos e programas de melhoramento, permitindo-se selecionar e estudar a herança de caracteres. Até meados da década de 60 esta variabilidade era observada somente por meio de caracteres morfológicos, limitando o número de marcadores possíveis de serem estudados. Posteriormente, passou-se a utilizar marcadores bioquímicos como as isoenzimas, as quais são consideradas marcadores moleculares pela definição de Ferreira e Grattapaglia (1995), permitindo a análise de um número maior de caracteres. Entretanto, tanto marcadores morfológicos como bioquímicos podem sofrer interação direta com o ambiente, e em alguns casos polimorfismo pode ser observado devido a essa interação.

A partir da década de 70 foram desenvolvidas inúmeras técnicas de verificação de polimorfismo diretamente no DNA, permitindo um número praticamente ilimitado de marcadores e também evitando interação direta com o ambiente. Entre outras técnicas, inicialmente se utilizou uma enzima de restrição associada a uma sonda, permitindo a observação de polimorfismo no tamanho dos fragmento de restrição. Esta técnica foi denominada de RFLP ("Restriction Fragment Length Polymorphisms") (Grodzicker et al., 1974). Embora esta técnica tenha se mostrado eficiente, a necessidade de grande quantidade de DNA de alto peso molecular e a utilização de sondas radioativas dificultou a utilização deste método em organismos de difícil cultivo, ou em laboratórios sem estrutura para manipulação de produtos radioativos.

Ao contrário, a técnica da PCR ("polymerase chain reaction"), que consiste na amplificação de uma sequência conhecida através da reação em cadeia da DNA polimerase (Mullis e Faloona, 1987; Saiki et al., 1988), permitiu que variabilidade fosse observada mesmo em organismos de difícil cultivo, pois não necessita de DNA de alto peso molecular, altamente purificado, e também não necessita de sondas radioativas. Em 1990, utilizando o princípio da PCR, foi desenvolvido um método 
denominado RAPD ("Random Amplified Polymorphic DNA"), que não necessita do conhecimento prévio da sequência a ser amplificada, e possibilita um número ainda maior de marcadores possíveis de serem mapeados, aumentando a possibilidade de se localizar locos ligados a caracteres quantitativos (QTL's).

\subsubsection{Reação em cadeia da Polimerase - PCR (Polymerase Chain Reaction)}

A técnica da PCR baseia-se na amplificação exponencial in vitro de uma sequência de DNA específica, sem no entanto necessitar da clonagem desse gene. Esta amplificação consiste de três etapas que são repetidas de forma cíclica. Estas etapas básicas são: a desnaturação do DNA, anelamento dos "primers" com as fitas de DNA e elongação deste "primer". Porém para que ocorra esta amplificação, a solução de DNA molde ("template") deve conter DNA polimerase, desoxirribonucleotídeos trifosfatados, magnésio e oligonucleotídeos ("primers") que atuarão como iniciadores.

Como colocado acima, a PCR inicia-se com a desnaturação do DNA devido à elevação da temperatua a $\pm 92^{\circ} \mathrm{C}$. Após esta desnaturação, os "primers" são adicionados e a temperatura é reduzida à $\pm 37^{\circ} \mathrm{C}$, para que ocorra o anelamento destes "primers" com a sequência alvo. Finalmente a temperatura é elevada para $\pm 72^{\circ} \mathrm{C}$, seguindo da adição da DNA polimerase para que esta enzima sintetize DNA a partir dos iniciadores ("extensão do primer"). Ao fim do ciclo será obtida uma cópia do DNA alvo, que servirá de molde durante os ciclos seguintes (figura 2.1), fazendo com que o número de cópias desta sequência aumente em progressão geométrica enquanto que outras regiões que se hibridizaram inespecificamente com apenas um dos "primers" aumentem em progressão linear, e não sejam detectadas posteriormente no gel.

Segundo Henson \& French (1993), vale ressaltar que as temperaturas acima citadas podem ser alteradas, pois DNAs ricos em $C+G$ suportam temperaturas mais elevadas de desnaturação devido a 
presença de três pontes de hidrogênio entre estas bases. $O$ anelamento dos oligonucleotídeos com o DNA alvo em temperatura mais elevada faz com que apenas "primers" especificos se liguem a este DNA, diminuindo a possibilidade de ocorrer amplificação de sequências que se parearam inespecificamente. Sabe-se porém que a especificidade destes "primers" depende de inúmeros fatores, como a sequência e o tamanho destes oligonucleotídeos, temperatura de anelamento e concentração de magnésio (Henson \& French, 1993).

Os "primers" para PCR são oligonucleotídeos de 18 a 30 nucleotídeos, os quais podem ser obtidos através de ${ }_{m}$ RNAs (cDNA), por meio de sequências de DNA genômico ou também pela síntese in vitro. Portanto, a obtenção destes segmentos iniciadores depende de um estudo prévio da sequência de DNA a ser amplificada. Como mostra a figura 2.1, na PCR utilizam-se dois "primers" distintos, que se anelam com a extremidade $3^{\prime} \mathrm{OH}$ da fita "sense" e da fita "non-sense" da sequência alvo.

Inicialmente foi utilizado o fragmento "Klenow" da DNA polimerase de Escherichia coli para a amplificação do DNA, porém esta enzima por ser termolábil, se desnatura ao final de cada ciclo, sendo portanto necessário a colocação de nova enzima após cada ciclo, tornando o método trabalhoso e demorado (Loureiro, 1994).

Entretanto, após 1988 a técnica da PCR desenvolveu-se rapidamente com a introdução de uma DNA polimerase termoestável (Taq DNA polimerase) obtida de Thermus aquaticus (Saiki et al., 1988). Esta bactéria habita águas quentes, e por esse motivo sua enzima DNA polimerase apresenta relativa estabilidade em temperatura de desnaturação do DNA, sendo possível a sua reutilização após cada ciclo de amplificação, diminuindo os custos e permitindo a automatização do ciclo térmico (Henson \& French, 1993). 


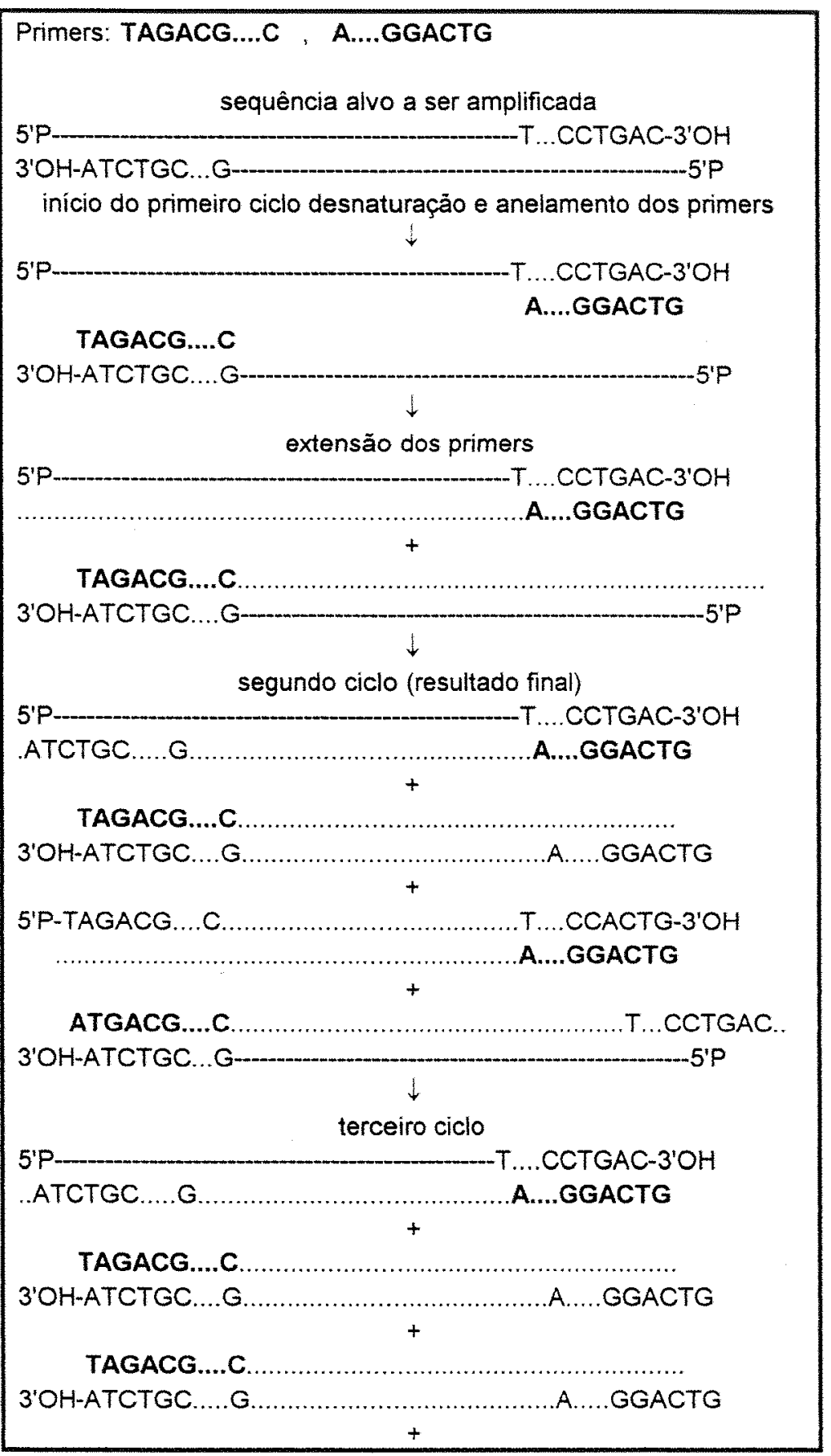

Figura 2.1 - Ciclos de amplificação de uma sequência alvo de DNA via reação em cadeia da DNA polimerase (PCR). Observar a desnaturação do DNA, anelamento dos dois "primers" e a extensão dos "primers". 


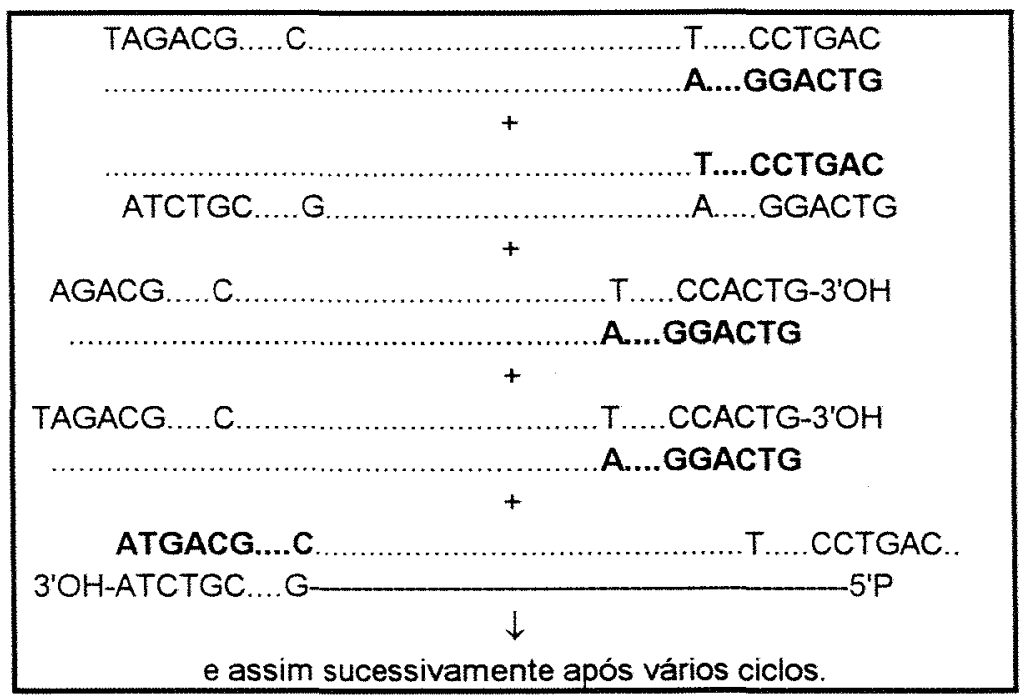

Figura 2.1 - Continuação

\subsubsection{Amplificação ao acaso de DNA polimórfico-RAPD (Random Amplified Polimorphic DNA).}

2.3.2.1. Condições e características do RAPD.

Como já mencionado, a análise de polimorfismo gerado por marcadores de RAPD, está baseada na técnica da PCR, ou seja, promove a amplificação de uma sequência de DNA por meio da extensão de um "primer".

Entretanto, no RAPD pode-se utilizar um único "primer" de sequência arbitrária, para se obter produtos de amplificação de diferentes isolados, espécies e gêneros (Williams et al.,1990; Welsh et al., 1990).

Estes oligonucleotídeos de sequência arbitrária, sofrerão anelamento ao acaso com o DNA genômico, e por essa razão "primers" de 6 a 10 nucleotídeos, terão maior probabilidade de encontrarem sequências homólogas do DNA alvo. No entanto, por serem utilizados "primers" de sequência única, para que ocorra amplificação de regiões do genoma em estudo, é necessário que estas sequências homólogas estejam nas duas fitas complementares do DNA, numa distância máxima de $4 \mathrm{~kb}$ (limite do 


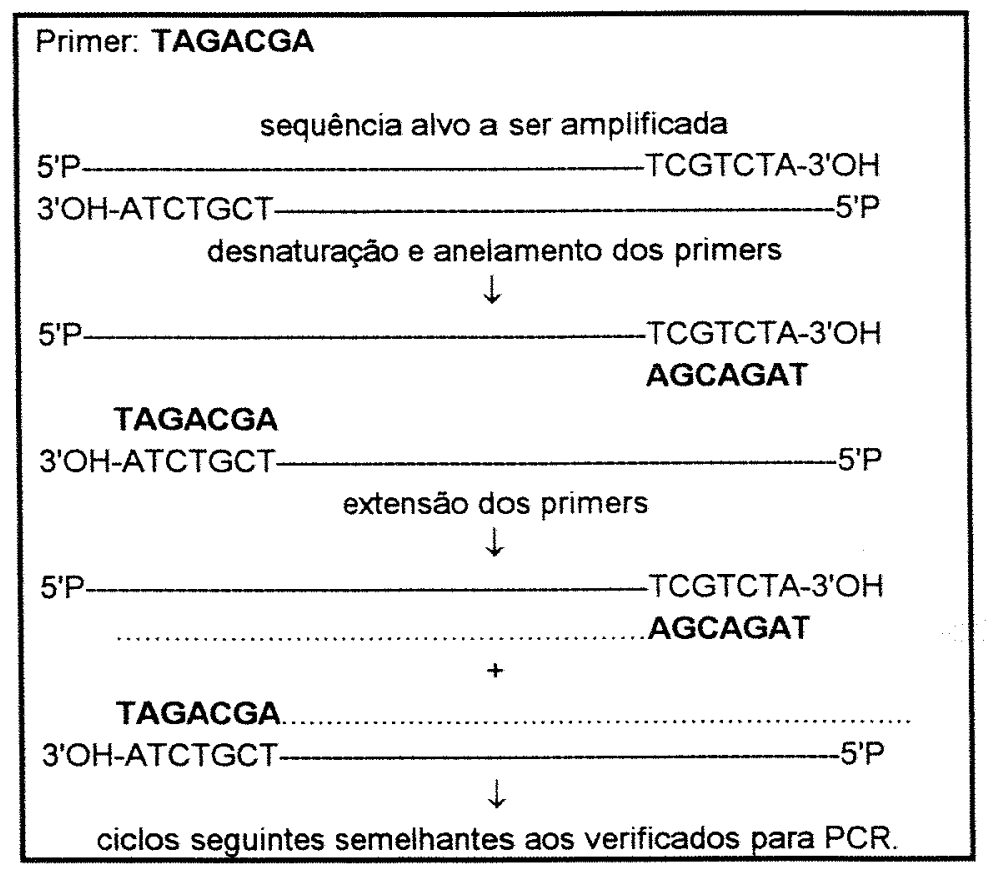

Figura 2.2 - Amplificação de uma sequência alvo de DNA via reação em cadeia da DNA Polimerase (PCR) com "primer" arbitrário (RAPD). Observar anelamento dos "primers" nas duas fitas complementares do DNA.

RAPD), para que ocorra uma amplificação semelhante a da PCR (figura 2.2).

Antes de verificar o polimorfismo gerado por marcadores de RAPD, é necessário realizar uma seleção de "primers" que amplifiquem um número maior de sequências do DNA, e que possibilitem uma melhor caracterização do material em estudo.

De acordo com Williams et al. (1990) a sequência e a composição de bases $C+G$ dos "primers" são fundamentais para a geração de polimorfismo, pois a troca de um único nucleotídeo do "primer" pode alterar o padrão de bandas amplificadas por ele, bem como para se obter níveis detectáveis de produtos de amplificação, é necessário que estes iniciadores sejam constituídos de $40 \%$ ou mais de bases $C+G$.

Os marcadores gerados por RAPD são dominantes, ou seja, não permitem verificar heterozigosidade nos indivíduos em estudo, como os marcadores de RFLPs. Eventualmente, devido a mutações de ponto ou 
alterações estruturais na sequência de DNA como inserções e deleções, os marcadores de RAPD podem apresentar codominância comportandose como marcadores de RFLPs (Ferreira \& Grattapaglia, 1995; Williams et al, 1990). Entretanto, de acordo com Williams et al, 1990, sabe-se que esse fato é muito raro, não sendo considerado durante análises desses marcadores, pois, para determinar essa codominância seria necessário a elaboração de sondas a partir desse DNA e promover a hibridização em outro gel, tornando o método mais trabalhoso e com custos mais elevados.

O RAPD apresenta inúmeras vantagens em relação ao RFLP e a PCR, pois o tempo e os custos desta análise são inferiores, já que são desnecessários estudos prévios para determinar a sequência do DNA alvo a ser amplificada, nem tão pouco necessita de filamento duplo de DNA altamente purificado e de alto peso molecular como o RFLP (Wang et al., 1993), e ao contrário desta técnica, a análise via RAPD não necessita de sondas radioativas e pode ser realizada com apenas poucos nanogramas de DNA (Williams et al. 1993). A necessidade de pouco DNA é especialmente útil para a análise de parasitas obrigatórios como Puccinia strifformis, onde a quantidade de DNA obtida em extrações de $20 \mathrm{mg}$ de urediósporos é insuficiente para a técnica de RFLP mas suficiente para realizar mais de uma centena de ensaios de RAPD (Chen et al., 1993).

Neste contexto, vale ressaltar que os marcadores de RAPD são obtidos com maior eficiência e com densidade maior de marcas, pois apresentam a capacidade de detectar variabilidade em regiões não acessadas por marcadores de RFLP devido à presença de sequências repetitivas como regiões telomêricas do mapa genético de soja (Williams et al.,1990), possibilitando no futuro a construção de mapas genéticos mais saturados que auxiliarão em programas de melhoramento, mapeamento genético e verificação de variabilidade em estudos evolutivos. 


\subsubsection{Aplicações da técnica de RAPD}

A capacidade do RAPD em fornecer mapas mais saturados, aliada às facilidades desta técnica em relação a outros métodos moleculares de caracterização genética, permitem que rapidamente estudos de sistemática e divergência evolutiva sejam conduzidos com expressivos resultados.

É importante enfatizar que os marcadores de RAPD são importantes ferramentas para se verificar a variabilidade existente entre diferentes isolados dentro de uma espécie, pois geram muito polimorfismo. De acordo com Aufavre-Brown et al. (1992), a análise destes marcadores permite a elaboração de coeficientes de similaridade que possibilitam verificar o grau de relação genética entre estes isolados. Estes marcadores aliados a testes de patogenicidade podem também permitir que relações evolutivas entre raças de $P$. striiformis sejam postuladas, bem como estudos de estrutura e evolução de populações deste patógeno sejam realizados (Chen et al., 1993).

Dentro deste contexto, Megnegneau et al. (1993) realizaram um estudo comparativo de diversas técnicas de caracterização de microrganismos, e concluiram que os resultados obtidos com RAPD são semelhantes aos obtidos com RFLP e isoenzimas, porém permitem uma análise mais detalhada. Entretanto Correl et al. (1993) verificaram que a análise de RAPD, com excessão a um "primer" foi semelhante a análise do DNA mitocondrial e RFLP, não distinguindo diferentes isolados de Colletotrichum orbiculare. De acordo com estes autores, embora o RAPD não tenha sido capaz de distinguir isolados dentro de vários haplótipos de DNAmt, este "primer" polimórfico, pode ser utilizado em estudos epidemiológicos de $C$. orbiculare em cucurbitas.

Espécies de Fusarium sp. são correntemente identificadas através de microscopia e características morfológicas de colônias, porém segundo Ouellet \& Seifert (1993), diferentes isolados podem ser morfologicamente idênticos, dificultando estudos de persistência deste patógeno em restos de cultura agrícola. Entretanto, a técnica de RAPD foi 
capaz de detectar variabilidade entre diferentes isolados, permitindo a realização deste estudo de persistência do patógeno em restos de cultura.

Como citado acima, o RAPD pode verificar variabilidade entre isolados morfologicamente idênticos, sendo, por esse motivo, uma importante ferramenta para se distinguir isolados patogênicos de não patogênicos de Fusarium oxysporum f. sp. dianthi (Manulis et al., 1994), como também para verificar polimorfismo entre isolados de $F$. solani $s p$ cucurbita (Crowhurst et al., 1991), Bipolanis mayds (Nicholson et al., 1993), C. orbiculare (Correl et al., 1993), C. truncatum (Vasconcelos et al., 1994), C. gloeosporioides (Hayden et al., 1994), Leptosphaeria maculans (Plummer et al., 1994),

Segundo Nicholson et al. (1993), a existência de fragmentos de DNA raça-específico gerados por RAPD podem ser clonados, sequenciados e utilizados na construção de "primers" específicos, que podem ser empregados na identificação de raças de fitopatógenos em material doente, sem a necessidade de isolamento do microrganismo.

2.3.2.3. Utilização de RAPD em estudos bacteriológicos.

Em bactérias, Williams et al. (1990) sugerem que o número de fragmentos de DNA amplificados por RAPD somente pode ser explicado pelo pareamento errado entre os "primers" utilizados e o DNA molde, pois o seu genoma é menor que o de fungos e plantas. Entretanto, Farber \& Addison (1994) utilizando duas extrações de DNA de Listeria monocytogenes, observaram resultados idênticos com estes DNAs, repetindo um mesmo "primer", mostrando a reprodutibilidade desta técnica para bactérias.

Portanto, a análise via RAPD pode ser perfeitamente utilizada em estudos bacteriológicos. Por exemplo, de acordo com Wang et al. (1993) estes marcadores de RAPD são mais eficientes que a eletroforese de enzimas para distinguir linhagens enteropatogênicas de Escherichia coli. Estes autores utilizaram 5 "primers" combinados e conseguiram distinguir 74 de 75 isolados desta bactéria, o que não foi possível com a 
utilização do diagnóstico eletroforético, utilizando-se de vinte sistemas enzimáticos como marcadores. Portanto esta técnica também se mostra muito sensivel para análise de variabilidade em bactérias, e por esse motivo, pode ser utilizada para subtipar diferentes isolados, explorando a variabilidade existente na espécie em estudo.

Dentro desse contexto, a técnica de RAPD foi utilizada para distinguir isolados clínicos de isolados ambientais de Legionella pneumophila (Sandery et al., 1994), e também para distinguir isolados de Bacillus spp., Bacillus licheniformis (Stephan et al., 1994) e Vibrio sp. (Martin-Kearley et al., 1994).

Esta técnica, como já colocado anteriormente, permite determinar distâncias e similaridades entre materiais genéticos, possibilitando a elaboração de dendrogramas que podem auxiliar o melhorista durante programas de melhoramento genético, como também elaborar questões a respeito da evolução filogenética dentro de um determinado grupo.

\subsubsection{Perfil plasmidial}

Plasmídios são moléculas de DNA extracromossomais, circulares, que se duplicam de forma autônoma na célula hospedeira (replicons), e podem ser encontrados em grande número de diversas formas em uma mesma célula. Plasmídios normalmente compreendem $2 \%$ do genoma bacteriano, porém em alguns casos podem constituir até um terço do total de DNA da célula. Entretanto estas estruturas circulares não apresentam genes que codificam proteínas essenciais para a célula, mas em determinadas condições ambientais podem conferir vantagens adaptativas ao hospedeiro, como resistência a antibióticos, degradação de compostos orgânicos, produção de bacteriocinas, fatores de virulência e especificidade a diferentes habitats.

Os plasmídios apresentam dois grupos de genes: o primeiro, responsável pela sua duplicação e disseminação, e outro, responsável por conferir novas características fenotípicas à célula hospedeira (Coplin, 
1989), as quais podem, como já citado anteriormente, determinar a especificidade do hospedeiro a diferentes habitats.

\subsubsection{Ocorrência de plasmídios em bactérias fitopatogênicas.}

A descoberta de plasmídios de virulência em bactérias do gênero Agrobacterium despertou ainda mais o interesse nestas estruturas. Segundo Panopoulos \& Peet (1985) o estudo de plasmídios como elementos acessórios em bactérias se concentra principalmente em: a) na detecção e caracterização de vários isolados, patovares e espécies; b) em pesquisa de características associadas a plasmídios; c) transmissão entre isolados; d) no desenvolvimento de ferramentas para análise genética in vivo e in vitro, e e) sistemas de transformação em plantas.

Plasmídios são estruturas observadas em praticamente todas as bactérias fitopatogênicas de importância econômica, entretanto, 0 número e o tamanho destes plasmídios são variáveis entre espécies e podem ser altamente conservados entre grupos que colonizam habitats semelhantes. Segundo Coplin (1989), plasmídios ou sequências altamente conservadas em bactérias coevoluíram com o hospedeiro, e por esse motivo se mantiveram estáveis nesses procariotos.

Neste contexto, foi observado que isolados de $E$. stewartii apresentam oito classes de plasmídios altamente conservados (Coplin et al., 1981), enquanto que para $E$. amylovora foi verificada a presença de um único plasmídio de $30 \mathrm{~kb}$ conservado entre diferentes isolados (Falkenstein et al., 1988). Plasmídios com variáveis niveis de homologia e/ou fragmentos de restrição conservados são comuns entre diferentes patovares de Pseudomonas syringae, entretanto, não foram observados plasmídios em comum entre as linhagens estudadas (Coplin, 1989), mostrando que sequências gênicas de interesse são mantidas mesmo após alterações estruturais.

Esta coevolução associada a patogenicidade pode ser observada também em Agrobacterium, pois, a capacidade de infectar 0 hospedeiro está associada a genes localizados em plasmídios, 
denominados $\mathrm{Ti}$ (indução de tumor) e Ri (indução de raíz) e somente bactérias que apresentam estes plasmídios infectam e causam tumores em seus hospedeiros (Brasileiro, 1993).

\subsubsection{Aplicações da determinação do perfil plasmidial}

O perfil plasmidial permite caracterizar isolados bacterianos quanto ao número e tamanho dos plasmídios presentes, bem como associar características fenotípicas de interesse com a informação genética contida nesses DNAs extracromossomais. Porém, o sucesso desta caracterização depende principalmente da extração plasmidial e para essa finalidade, várias metodologias foram desenvolvidas (Birnboim \& Doly,1979; Kado \& Liu,1981; De Sal et al., 1988).

Portanto, por meio do perfil plasmidial é possível identificar bactérias patogênicas após cultivo em meio sintético ou diretamente em amostras de tecido vegetal, entretanto, esta identificação in situ depende da construção de sondas de DNA plasmidial específico. Zhao \& Aoki (1992), sugerem que estas sondas sintetizadas a partir de plasmídio raçaespecífico também permitiram que fossem realizados estudos epidemiológicos em isolados patogênicos de Pasteurella piscicida de várias regiões do Japão. Foi verificado que estes isolados apresentam um plasmídio de $5,1 \mathrm{~kb}$, o qual está ausente em todas as bactérias taxonomicamente relacionadas, estudadas nesse trabalho, bem como em isolados de $P$. piscicida dos Estados Unidos. Portanto, além de permitir a elaboração de sondas específicas, a presença deste plasmídio em todos os isolados japoneses sugere que o mesmo esteja relacionado com a sobrevivência e patogenicidade dessa bactéria.

Como já citado, os plasmídios apresentam genes que podem resultar em vantagens adaptativas para a célula hopedeira. Quando estas vantagens estão presentes em organismos de ambientes específicos, estes genes são conservados na população. Neste contexto, MoënneLoccoz et al. (1994) estudaram a persistência de inoculantes de Rhizobium no campo, e constataram a presença de um plasmídio de $176 \mathrm{MDa}(277,2$ 
kb), instável "in vitro", mas presente em uma linhagem comercial (162Y16) utilizada neste campo. Portanto, este plasmidio deve se manter nesta linhagem por conferir importante vantagem adaptativa neste ambiente.

Em isolados de Salmonella enteritidis foi verificada a presença de plasmídios "conservados" de 59,85 kb em humanos (Erdem et al., 1994), e $54 \mathrm{~kb}$ em perus (Bichler et al., 1994). Segundo os autores, estes plasmídios podem estar associados à virulência destas bactérias.

Caballero-Mellado \& Martinez-Romero (1994) constataram baixa divergência genética, em isolados endofíticos de Acetobacter diazotrophicus, por meio de DNA "fingerprints", isoenzimas e perfil plasmidial, e embora características fenotípicas tenham sido mapeadas em genes cromossômicos, os autores sugerem que os genes plasmidiais altamente conservados devem contribuir para o vigor da interação entre $A$. diazotrophicus e cana-de-açucar. Esses resultados sugerem que populações adaptadas a ambientes específicos apresentam baixa divergência genética, pois, a seleção ambiental imposta a estes microrganismos diminui a variabilidade da população, tornando-os mais específicos a estes locais.

Entretanto, Wiebe \& Campbell (1993) e Liang et al. (1994), observaram baixa similaridade plasmidial entre diferentes patovares de $P$. syringae e concluíram que existe pequena quantidade de trocas genéticas entre estes patovares. Porém, estudos de homologia DNA-DNA e restrição de fragmentos devem ser realizados para se verificar a existência de fragmentos conservados nestes plasmídios mesmo após alterações estruturais dos mesmos, pois, como afirmou Coplin (1989) em sua revisão, plasmídios de diferentes patovares de $P$. syringae apresentam níveis variados de homologia.

Pode-se então verificar que o perfil plasmidial como qualquer outra técnica de caracterização molecular possibilita a obtenção de informações genéticas diretamente a partir do conteúdo de DNA, evitando possiveis distorções decorrentes de interações com o ambiente, porém resultados mais consistentes são obtidos quando diferentes técnicas (tanto moleculares como clássicas) são utilizadas em conjunto. 


\section{MATERIAIS E MÉTODOS}

\subsection{Material Vegetal}

\subsubsection{Local de Coleta das amostras}

O material vegetal utilizado no presente trabalho foi coletado no Centro de Citricultura Sylvio Moreira (CCSM) do Instituto Agronômico de Campinas (IAC), localizado no município de Cordeirópolis-S.P, no mês de setembro de 1994. Nesta época foi observado um período de seca entre os meses de julho a outubro de 1994 .

\subsubsection{Porta-enxertos}

Foram coletadas folhas e sementes de 8 cultivares e 2 híbridos (tabela 3.1), utilizados como porta-enxertos de citros. Todas as plantas utilizadas fazem parte da coleção de porta enxertos do CCSM, para produção de sementes. Os quais são mantidos em campo enxertados sobre limão cravo limeira (Citrus limonia).

Para melhor padronização da coleta, foi retirada apenas a terceira ou quarta folha de ramos localizados na face externa da planta, a uma altura aproximada de um metro do solo.

Para coleta de sementes, foram retirados frutos maduros assintomáticos a uma altura de aproximadamente um metro do solo. Estes frutos foram levados para o laboratório, retiradas suas sementes e tratadas para desinfecção superficial. 
Tabela 3.1 - Relação de porta-enxertos de citros utilizados no trabalho.

\begin{tabular}{lccl}
\hline \multicolumn{1}{c}{ Nome vulgar } & Código & Categoria & Nome cientifico \\
\hline \hline Laranja caipira comum & $\mathrm{CL}$ & cultivar & Citrus sinensis \\
\hline Laranja caipira D.A.C. & LD & cultivar & C. sinensis \\
\hline Limão cravo limeira & LC & cultivar & C. limonia \\
\hline Limão volcameriano & LV & cultivar & C. volcamerian \\
\hline Tangerina cleópatra & TC & cultivar & C. resnhi \\
\hline Tangerina sunki & TS & cultivar & C. sunki \\
\hline Trifoliata kryder & CK & cultivar & Poncirus trifoliata \\
\hline Trifoliata limeira & LT & cultivar & P. trifoliata \\
\hline Citrange troyer & CT & hibrido & P. trifoliata X C. sinensis \\
\hline Tângelo orlando & TO & hibrido & C. paradisi X C. reticulata \\
\hline
\end{tabular}

\subsection{Meios de Cultura}

\subsubsection{Meio TSA - Tryptic Soy Agar}

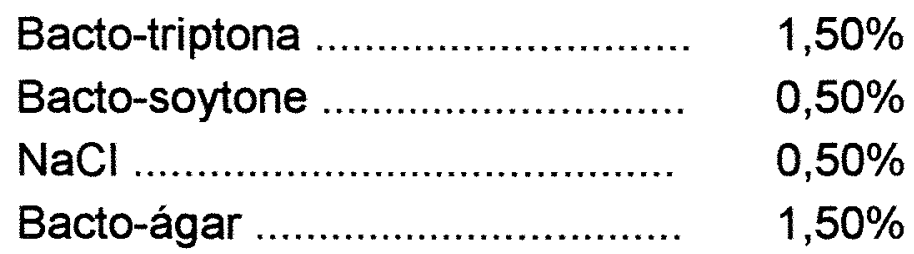

$$
\mathrm{pH}=7,3
$$

Para esterilização, este meio foi autoclavado a $115^{\circ} \mathrm{C}$ por 20

minutos.

\subsubsection{Caldo LB - Luria e Bertani.}

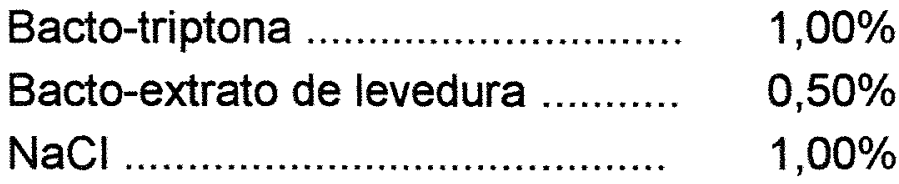

$$
\mathrm{pH}=7,5
$$

Para esterilização, este meio foi autoclavado a $115^{\circ} \mathrm{C}$ por 20 minutos. 
3.2.3. Meio LBA - Luria e Bertani Ágar.

Este meio foi preparado segundo o item 3.2.2, acrescido de $1,5 \%$ de ágar.

\subsubsection{Meio NA - Nutriente Ágar}

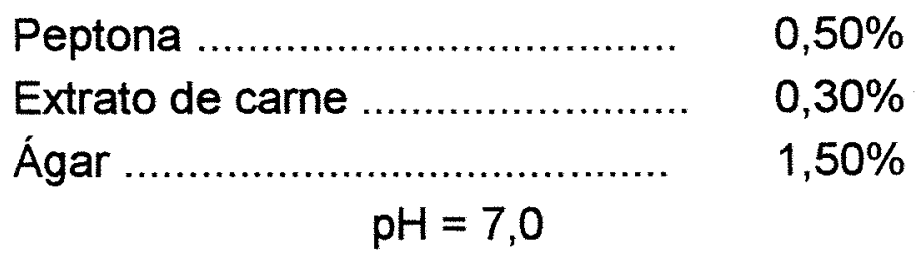

Para esterilização, este meio foi autoclavado a $115^{\circ} \mathrm{C}$ por 20 minutos.

\subsubsection{Meio Aveia}

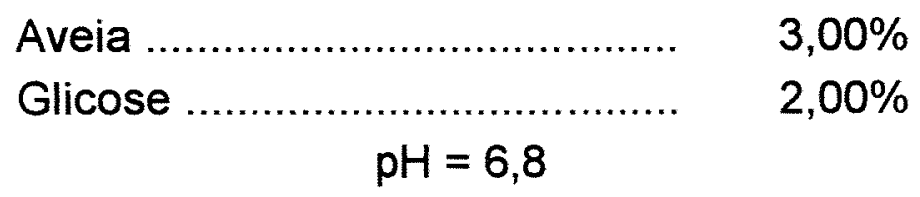

A aveia foi fervida em água destilada durante 30 minutos $\mathrm{e}$ filtrada em gaze. Após a filtragem acrescentou-se a glicose e autoclavou a $115^{\circ} \mathrm{C}$ por 20 minutos.

\subsubsection{Meio Aveia sólido.}

Ao meio aveia (item 3.2 .5 ) foi adicionado $1,5 \%$ de ágar. 
3.2.7. Meio EPM (Toledo et al., 1982)

Solução Base A (composição e preparo do meio):

Triptona

$1,00 \%$

Extrato de carne

$0,20 \%$

$\mathrm{NaCl}$

$0,50 \%$

$\mathrm{NaH}_{2} \mathrm{PO}_{4} \cdot 5 \mathrm{H}_{2} \mathrm{O}$

$0,20 \%$

L-triptofano

$0,10 \%$

Azul de bromotimol (sol 1\%)

$0,20 \%$

Ágar

$1,10 \%$

$$
\mathrm{pH}=7,4
$$

Após dissolução dos componentes, ajustou $0 \mathrm{pH}$, acrescentou o ágar e esterilizou a $115^{\circ} \mathrm{C}$ durante 20 minutos.

Solução Base B (indicador e substratos):

Citrato de ferro amoniacal

$2,35 \%$

$\mathrm{Na}_{2} \mathrm{~S}_{2} \mathrm{O}_{3} \cdot 5 \mathrm{H}_{2} \mathrm{O}$

$2,35 \%$

Glicose

$11,76 \%$

Uréia

$47,06 \%$

Os compostos foram misturados em água e aqueceu em banho-maria a $65^{\circ} \mathrm{C}$ por 1 hora, agitando constantemente até a completa dissolução.

Preparo final:

Solução A .............................. 1000,0ml

Solução B

$17,5 \mathrm{ml}$

Após misturar as duas soluções, foi distribuido assepticamente $4 \mathrm{ml}$ deste meio por tubo e inclinados. 
3.2.8. Meio MILI.

\begin{tabular}{|c|c|}
\hline Extrato de levedura & $0,30 \%$ \\
\hline Peptona & $1,00 \%$ \\
\hline Triptona . & $1,00 \%$ \\
\hline L-lisina & $1,00 \%$ \\
\hline Glicose ...... & $0,10 \%$ \\
\hline Bromo cresol púrpura .................... & $0,002^{\circ}$ \\
\hline $\begin{array}{c}\text { Ágar } \ldots \ldots \ldots \ldots \ldots \ldots \ldots \ldots \ldots \ldots \ldots \ldots \ldots \ldots \ldots \ldots \ldots \ldots \ldots \\
p H\end{array}$ & 0 \\
\hline
\end{tabular}

Após o preparo, o meio foi distribuído em volume de $5,0 \mathrm{ml}$ por tubos, e autoclavado a $115^{\circ} \mathrm{C}$ por 20 minutos.

\subsubsection{Meio Citrato de Simmons}

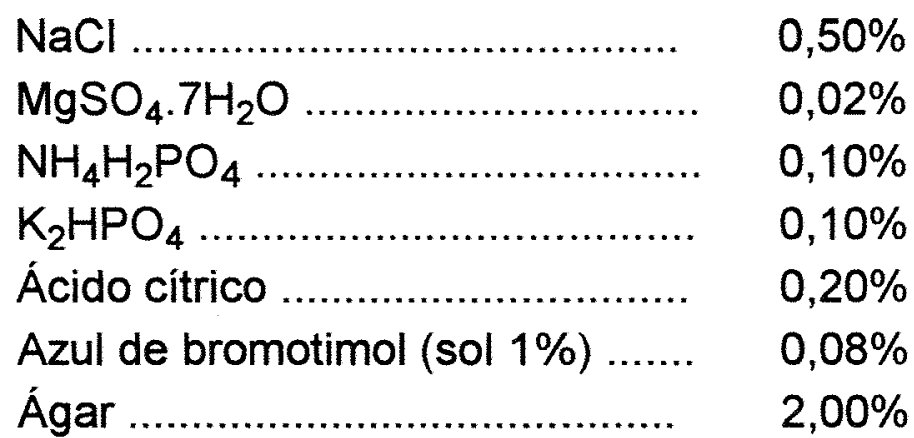

Os sais foram solubilizados em água destilada e posteriormente foi acrescentado o ácido cítrico e o pH ajustado para 6,8. Foi adicionado a solução de azul de bromotimol, o ágar e autoclavado a $115^{\circ} \mathrm{C}$ por 20 minutos No momento do uso o meio foi distribuído em tubos contendo $3,0 \mathrm{ml}$, os quais foram deixados solidificar inclinados. 
3.2.10. Meío básico para açúcares

\begin{tabular}{|c|c|}
\hline 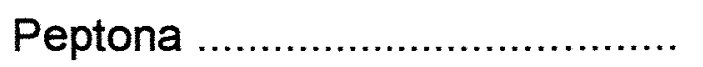 & $1,00 \%$ \\
\hline $\mathrm{NaCl}$. & $0,50 \%$ \\
\hline $\begin{array}{c}\text { Azul de bromotimol (sol. 1\%) } \ldots \ldots \\
\qquad \mathrm{pH}=7,2\end{array}$ & $0,20 \%$ \\
\hline
\end{tabular}

3.2.11. Meio para oxidação-fermentação da glicose (O/F)

\begin{tabular}{|c|c|}
\hline Peptona & $0,20 \%$ \\
\hline $\mathrm{NaCl}$ & $0,50 \%$ \\
\hline $\mathrm{KH}_{2} \mathrm{PO}_{4}$ & $0,03 \%$ \\
\hline Azul de bromotimol (sol. 1\%) ...... & $0,08 \%$ \\
\hline Ágar f..................................... & $0,30 \%$ \\
\hline
\end{tabular}

3.2.12. Meio para verificação de atividade amilolítica

Ao meio NA (item 3.2.4) foi acrescentado $1,0 \%$ de amido e autoclavado a $115^{\circ} \mathrm{C}$ por 20 minutos.

3.2.13. Meio para verificação de atividade gelatinásica

\begin{tabular}{|c|c|}
\hline Extrato de carne & $0,30 \%$ \\
\hline Peptona & $0,50 \%$ \\
\hline ................ & $12,00 \%$ \\
\hline
\end{tabular}


Para esterilização, este meio foi autoclavado a $115^{\circ} \mathrm{C}$ por 20 minutos.

\subsubsection{Meio para detecção de indol}

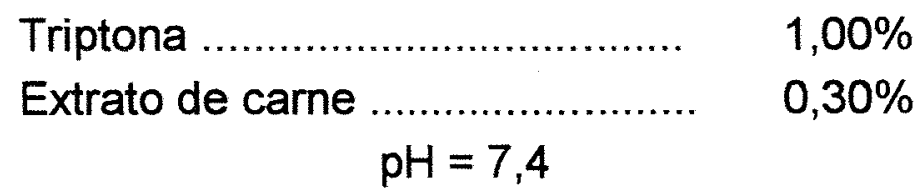

Para esterilização, este meio foi autoclavado a $115^{\circ} \mathrm{C}$ por 20 minutos.

\subsubsection{Meio para redução de Nitrato}

Ao meio NA (item 3.2.4) foi acrescentado $0,1 \%$ de $\mathrm{KNO}_{3}$ e distribuído em tubos com $5,0 \mathrm{ml}$ de meio cada. Foi autoclavado a $115^{\circ} \mathrm{C}$ por 20 minutos, e os tubos foram inclinados para obter uma superfície ampla.

3.2.16. Meio para reação de Voges-Proskauer (VP)

\begin{tabular}{|c|c|}
\hline eptona ... & $0,50 \%$ \\
\hline${ }_{2} \mathrm{HPO}_{4}$ & $0,50 \%$ \\
\hline 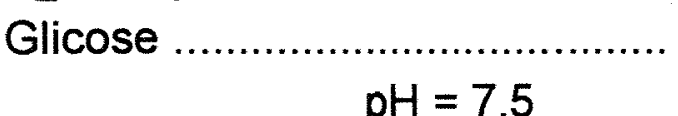 & 0500 \\
\hline
\end{tabular}

A peptona e $\mathrm{O}_{2} \mathrm{HPO}_{4}$ foram dissolvidos em água destilada, $\circ \mathrm{pH}$ foi ajustado, o meio foi distribuido em tubos com $1,5 \mathrm{ml}$ cada $\mathrm{e}$ autoclavado a $115^{\circ} \mathrm{C}$ por 20 minutos. Posteriormente a glicose foi adicionada. 


\subsection{Soluçōes e Tampões}

\subsubsection{Solução de cristal violeta.}

Solução A: Cristal violeta .......... $\quad 0,010 \%$ Etanol $95 \%$.............. 20,00 ml

Solução B: Oxalato de amônio .... $\quad 0,001 \%$ Água destilada .......... $80,00 \mathrm{ml}$

As soluções $\underline{A}$ e $\underline{B}$ foram misturadas e estocadas.

3.3.2. Solução de lugol
lodo
$0,33 \%$
lodeto de potássio
$0,67 \%$
Água destilada $300,0 \mathrm{ml}$

\subsubsection{Solução de safranina}

Safranina

$0,025 \%$

Etanol $50,0 \mathrm{ml}$

Água destilada $50,0 \mathrm{ml}$

Para o uso, dilui-se esta solução (1:10) em água destilada.

\subsubsection{Solução de verde malaquita}

Verde malaquita

Água destilada
$0,005 \%$

$20,0 \mathrm{ml}$

3.3.5. Solução de RNAse

RNAse

$10 \mathrm{mg} / \mathrm{ml}$

Tris- $\mathrm{HCl} \mathrm{pH}=8,0$ $10 \mathrm{mM}$

$\mathrm{NaCl}$ $15 \mathrm{mM}$ 
3.3.6. Solução de fenol saturado (modificado de Sambrook et al., 1989)

Foi solubilizado $50 \mathrm{~g}$ de fenol cristalizado em banho-maria e adicionado um volume de tampão Tris- $\mathrm{HCl}(0,2 \mathrm{M}, \mathrm{pH}=8,0)$. Foi deixado sob agitação por 30 minutos para equilibrar $0 \mathrm{pH}$, a fase aquosa foi retirada e acrescentado novamente o tampão. Este processo foi repetido até que $\circ \mathrm{pH}$ da fase fenólica estivesse em 8,0. A fase aquosa foi novamente retirada, adicionado $1 / 10$ do volume final de tampão $\mathrm{Tris}-\mathrm{HCl}$ $(0,2 \mathrm{M}, \mathrm{pH}=8,0)$ e estocado em frasco escuro a $4^{\circ} \mathrm{C}$.

\subsubsection{Solução de $\alpha$-naftol}

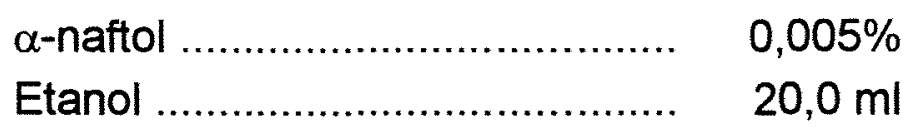

3.3.8. Reagentes para o teste do nitrato

$\begin{array}{rr}\text { Solução A: Ácido sulfanílico ........ } & 0,80 \% \\ \text { Ácido acético } 5 \mathrm{~N} \ldots \ldots . . & 20,0 \mathrm{ml} \\ \text { Solução B: } \alpha \text {-naftilamina ............ } & 0,50 \% \\ \text { Ácido acético } 5 \mathrm{~N} \ldots \ldots . & 20,0 \mathrm{ml}\end{array}$

\subsubsection{Reagente de Kovacs}

p-dimetilaminobenzaldeido ......... $0,005 \%$

Álcool amilico .......................... 75,0 ml

$\mathrm{HCl}$ concentrado ....................... 25,0 ml

Solubilizou-se o p-dimetilaminobenzaldeido no álcool em banho-maria $\left(50-55^{\circ} \mathrm{C}\right)$ e adicionou-se o ácido. Este reagente foi armazenado em frasco escuro a $4^{\circ} \mathrm{C}$. 


\subsubsection{Clorofane}

Fenol saturado

Clorofórmio
$50,00 \%$

$50,00 \%$

\subsubsection{Clorofil}

Clorofórmio

$96,00 \%$

Álcool isoamílico

$4,00 \%$

\subsubsection{Tampão TEN}

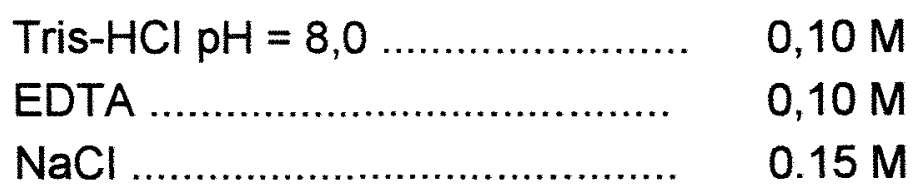

\subsubsection{Tampão TE}

Tris- $\mathrm{HCl} \mathrm{pH}=8,0$ EDTA
$10,0 \mathrm{mM}$

$1,0 \mathrm{mM}$

\subsubsection{Tampão TEB $10 \mathrm{X}$}

$\begin{array}{lr}\text { Trizma base } \mathrm{pH}=8,0 \ldots \ldots \ldots \ldots \ldots \ldots & 10,80 \% \\ \text { Ácido Bórico } \ldots \ldots \ldots \ldots \ldots \ldots \ldots \ldots \ldots . & 5,50 \% \\ \text { EDTA } \ldots \ldots \ldots \ldots \ldots \ldots \ldots \ldots \ldots \ldots \ldots \ldots . . & 0,93 \%\end{array}$

A solução foi autoclavada a $115^{\circ} \mathrm{C}$ por 20 minutos e guardada em temperatura ambiente. No momento do uso foi diluída (1:10) em água milli-Q. 


\subsubsection{Tampão STET}

Sacarose

$8,00 \%$

Triton X-100

$0,10 \%$

EDTA

$50,0 \mathrm{mM}$

Tris- $\mathrm{HCl}-\mathrm{pH}=8,0$

$50,0 \mathrm{mM}$

3.3.16. Tampão de corrida

Azul de bromofenol

$0,25 \%$

Xileno cianol

$0,25 \%$

Ficol

$15,00 \%$

3.3.17. Gel de agarose $(0,8 \%)$

Agarose

Tampão TEB $1 X$
$0,80 \%$

$100,0 \mathrm{ml}$

3.3.18. Gel de agarose $(1,4 \%)$

Agarose

Tampão TEB $1 X$
$1,40 \%$

$100,0 \mathrm{ml}$

\subsubsection{Solução estoque de dNTP's}

Os 4 dNTP's (dATP, dTTP, dCTP, dGTP) foram adquiridos (Gibco) numa concentração de $100 \mathrm{mM}$. Para uso os dNTP's foram misturados e diluídos em água de modo a se obter uma concentração estoque de 2,5 mM de cada dNTP. 


\subsection{Isolamento de Microrganismos Endofíticos}

\subsubsection{Desinfecção das folhas e isolamento dos microrganismos}

As folhas foram lavadas em água corrente, e deixadas durante 20 horas com o peciolo mergulhado em solução aquosa do fungicida benomyl $(80 \mu \mathrm{g} / \mathrm{ml})$. Posteriormente, as bordas destas folhas foram recortadas e desinfectadas com banhos sucessivos de álcool $70 \%$ (1 minuto), solução de hipoclorito de sódio 3\% (3 minutos) e álcool $70 \%$ (30 segundos). O excesso de álcool foi retirado com banho de água esterilizada.

Após a desinfecção, a borda dos fragmentos foliares tratados foram recortadas e estes fragmentos divididos em 6 pedaços de aproximadamente $4 \times 4 \mathrm{~mm}$, os quais foram colocados em placas de Petri contendo meio TSA (item 3.2.1) + fungicida benomyl $(40 \mu \mathrm{g} / \mathrm{ml}) \mathrm{e}$ incubados a $28^{\circ} \mathrm{C}$ durante 4 dias.

As bactérias endofiticas que cresceram a partir do primeiro dia ao quarto dia de cultivo, foram retiradas com alça de platina ou palito esterilizado e semeadas em meio LBA (item 3.2.3) inclinado em tubos, as quais posteriormente foram purificadas.

\subsubsection{Purificação das colônias bacterianas}

As colônias foram purificadas através da técnica de esgotamento por estrias cruzadas, em placas contendo o meio LBA (item 3.2.3). Este processo foi repetido duas vezes com a finalidade de se obter colônias isoladas.

Após a obtenção de colônias puras, estas foram semeadas em tubos de LBA (item 3.2.3) e/ou NA (item 3.2.4) para estoque. 


\subsubsection{Verificação da frequência de isolamento}

fórmula:

A frequência de isolamento $(F I)$ foi obtida por meio da $F I=B / F$, onde:

$F$ é o número de fragmentos foliares plaqueados, e $\mathrm{B} \circ$ número de fragmentos foliares infectados.

\subsection{Identificacão das bactérias isoladas}

Para a identificação dos isolados bacterianos, foi utilizado como padrão, bactérias já identificadas: Enterobacter cloacae isoladas em Londrina (gentilmente cedida pela Profa. Dra. Halha O. Saridakis do Depto. de Patologia Geral/Universidade Estadual de Londrina), Bacillus megaterium, B. thuringiensis, B. polymixa, Clavibacter sp., Erwinia herbicola (gentilmente cedidas pelo Dr. Rui P. Leite do Instituto Agronômico do Paraná/IAPAR/Londrina)

\subsubsection{Verificação da morfologia}

3.5.1.1. Colônia bacteriana

A morfologia das colônias bacterianas foi verificada após o crescimento das bactérias em meio LBA (item 3.2.3), onde observou-se forma, borda, pigmentação, superfície, consistência e odor.

\subsubsection{Célula bacteriana}

Para a verificação da morfologia da célula bacteriana, foi realizada a coloração de Gram (item 3.5.2) e a seguir as lâminas foram observadas em microscópio óptico, sendo então verificados forma, tamanho, grupamento, e quando presentes a posição de endósporos. 
3.5.1.3. Motilidade

A verificação da motilidade foi feita em lâmina côncava em microscópio óptico, com células bacterianas previamente crescidas em meio indol (item 3.2.14), ou por meio do crescimento em meio MILI (item 3.2.8)

\subsubsection{Coloração de Gram}

Foi preparado um fino esfregaço de células jovens em lâmina, e secado levemente para fixar. Em seguida foi tratado como a seguir:

- corado em solução de cristal violeta (item 3.3.1) por 1 minuto,

- corado em solução de lugol (item 3.3.2) por 1 minuto e lavado em solução de etanol : acetona (3:1), e lavado em água.

- corado em solução de safranina (item 3.3.3) por 30 segundos, lavado em água corrente e secado em papel absorvente.

As células gram positivas se coraram de violeta devido a retenção dos corantes iniciais (cristal violeta e lugol), enquanto que as células gram negativas se coraram de rosa devido à coloração de contraste com safranina.

\subsubsection{Coloração de Wirtz (coloração para esporos)}

Após feito um esfregaço de cultura bacteriana em lâmina, e secado levemente no calor para fixar. Este foi em seguida recoberto com solução de verde malaquita (item 3.3.4), permanecendo por 15 minutos. Em seguida, foi lavado com água corrente e corado com safranina (3.3.3) por 30 segundos. A lâmina foi novamente lavada em água corrente, seca e observada ao microscópio ótico. 
Devido a retenção do corante verde malaquita, esporos se coram de verde, enquanto que células vegetativas se coram de rosa (safranina).

\subsubsection{Identificação bioquímica}

3.5.4.1. Identificação presuntiva de bastonetes gram negativos

3.5.4.1.1. EPM (Ácido e gás de glicose, urease, $\mathrm{H}_{2} \mathrm{~S}$, L-triptofano desaminase)

Com uma agulha, foram inoculadas as bactérias por meio de picada profunda no meio EPM (item 3.2 .7 ) e incubadas a $28^{\circ} \mathrm{C}$ por 24 horas. A formação de bolhas indicou a produção de gás a partir da glicose, a passagem da cor do meio de verde para amarelo, na base do tubo, indicou que houve produção de ácido a partir da glicose, porém, quando houve produção de $\mathrm{H}_{2} \mathrm{~S}$ neste mesmo local houve formação de pigmentos pretos. A coloração verde escura na superfície do meio indicou produção de L-triptofano desaminase. A produção de urease foi verificada quando a cor do meio passou de verde para azul

\subsection{MILI (motilidade, indol-lisina)}

As culturas bacterianas foram inoculadas com auxilio de uma agulha no interior do tubo contendo o meio MILI (item 3.2.8), e incubadas a $28^{\circ} \mathrm{C}$ por 24 horas. Após o crescimento bacteriano foi feito a leitura: a presença de zonas túrbidas ao redor da picada indicou motilidade positiva, quando a cor do meio passou de roxo-violeta para amarelo indicou lisina descarboxilase negativa, enquanto que a produção de indol a partir de triptofano foi verificada colocando 3-5 gotas do reagente de Kovacs (item 3.3.9), o teste foi considerado positivo quando ocorreu formação de anel vermelho (anel indólico). 


\subsection{Utilização de citrato}

A bactéria foi inoculada por meio de estrias na superfície do meio de citrato de Simmons (item 3.2.9) e incubada a $28^{\circ} \mathrm{C}$. $\mathrm{O}$ crescimento bacteriano e a alteração da coloração do meio foram examinados diariamente durante 7 dias. $O$ resultado positivo foi caracterizado pela passagem da cor do meio de verde para azul.

\subsubsection{Utilização de diferentes fontes de carbono}

No momento do uso, foi adicionada a fonte de carbono* (glicose, arabinose, manitol, amido, raffinose, trealose e melibiose) numa concentração final de $1 \%$ ao meio básico para açúcares (item 3.2.10), e distribuidos $5,0 \mathrm{ml}$ em tubos esterilizados. $O$ inóculo foi feito com alça de platina $e$ incubado a $28^{\circ} \mathrm{C}$ por 7 dias. $O$ resultado positivo foi caracterizado pela passagem da cor do meio de verde para amarela devido a acidificação do meio e queda do $\mathrm{pH}$.

* solução estoque esterilizada (a $20 \%$ em água).

3.5.4.3. Teste de oxidação e fermentação da glicose (O/F glicose)

Com auxílio de uma agulha, foi feito um inóculo por picada profunda em dois tubos contendo o meio para teste de O/F (item 3.2.11). Sobre a superfície de um dos tubos foi colocado $3,0 \mathrm{ml}$ de óleo mineral esterilizado e ambos os tubos foram incubados a $28^{\circ} \mathrm{C}$ por 72 horas.

A mudança da cor do meio de verde para amarela nos dois tubos indicou a fermentação da glicose (F), mas se esta alteração ocorreu apenas na superficie do tubo sem óleo indicou oxidação da glicose $(0)$. Entretanto, se houve crescimento bacteriano e o meio passou de verde para azul, não ocorreu utilização da glicose, mas houve elevação do pH devido a produtos do metabolismo proteico. 
3.5.4.4. Hidrólise do amido

Os isolados bacterianos foram inoculados em placas de petri contendo o meio de amido (item 3.2.12) e incubados a $28^{\circ} \mathrm{C}$ por 48 horas. Após o crescimento estas colônias foram cobertas com solução de lugol (item 3.3.2). O resultado positivo foi caracterizado por um halo incolor ao redor da colônia bacteriana.

\subsubsection{Hidrólise da gelatina}

O meio de gelatina (item 3.2.13) foi deixado a $4^{\circ} \mathrm{C}$ durante 2 horas para solidificar. $O$ inóculo foi por picada profunda neste meio com agulha. Incubou-se a $28^{\circ} \mathrm{C}$ durante 30 dias.

Para observações diárias, os tubos inoculados juntamente com um tubo controle (sem inóculo) foram colocados em refrigerador a $4^{\circ} \mathrm{C}$ por 1 hora. A manutenção do estado líquido do meio indicou a hidrólise da gelatina.

3.5.4.6. Crescimento em diferentes temperaturas

As bactérias foram inoculadas em meio NA (item 3.2.4) e incubadas em diferentes temperaturas $\left(10,28\right.$ e $\left.45^{\circ} \mathrm{C}\right)$ durante 7 dias, para se verificar o crescimento.

\subsubsection{Crescimento em $\mathrm{NaCl} 5 \%$}

Foi utilizado o meio NA (item 3.2.4) acrescido de $\mathrm{NaCl}$ na concentração de $5 \%$. Após o inóculo, incubou-se a $28^{\circ} \mathrm{C}$ por 72 horas, para se verificar o crescimento bacteriano. 
3.5.4.8. Crescimento em diferentes $\mathrm{pHs}$

Foi utilizado o meio LB (item 3.2.2) com o pH desejado (5,8 e $6,7)$. Após o inóculo, incubou-se a $28^{\circ} \mathrm{C}$ por 72 horas para se verificar o crescimento bacteriano.

\subsubsection{Catalase}

Com auxílio de um palito de madeira, foi coletado uma amostra de colônia bacteriana, e colocada sobre uma gota de $\mathrm{H}_{2} \mathrm{O}_{2}(3 \%)$. 0 resultado positivo foi caracterizado pelo desprendimento de gás imediatamente ou após 5 minutos.

\subsubsection{Oxidase}

Sobre um papel de filtro impregnado com 2-3 gotas de dimetil-p-fenilenediamina (1\%), colocou-se amostras de colônia bacteriana. O resultado positivo foi determinado pelo aparecimento de coloração violeta sobre o papel em 10 segundos.

\subsubsection{Produção de indol}

As bactérias foram semeadas em caldo para determinação da produção de Indol (item 3.2 .14 ) e incubadas a $28^{\circ} \mathrm{C}$ por 48 horas. Após o crescimento, foi adicionado 4 gotas do reagente de Kovacs (item 3.3.9). Um halo vermelho na fase alcóolica indicou presença de indol.

\subsubsection{Redução de nitrato a nitrito}

As bactérias foram inoculadas em meio com nitrato (item 3.2.15) e incubadas a $28^{\circ} \mathrm{C}$ por 48 horas. Após o crescimento foram adicionadas 2 gotas da solução $A$ e 2 gotas da solução $B$ dos reagentes para o teste do nitrato (item 3.3.8). O resultado positivo foi caracterizado 
pelo aparecimento de uma coloração vermelha intensa na superfície do meio.

\subsubsection{Reação de Voges-Proskauer (VP)}

Com auxilio de uma alça de platina, as bactérias foram inoculadas em tubos contendo o meio para VP (item 3.2.16) e incubadas a $28^{\circ} \mathrm{C}$ por 72 horas. A leitura da reação foi feita alcalinizando o meio com 2-3 gotas de $\mathrm{KOH}(40 \%)$ e posteriormente adicionaram-se 3-5 gotas de solução de $\alpha$-naftol (item 3.3.7). O teste positivo foi caracterizado pela presença de um halo vermelho, alguns segundos após a colocação do reagente. Este halo se fromou a partir da superfície de contato com $\circ \mathrm{O}_{2}$, devido a axidação da acetoína.

\subsection{Verificacão da interacão fungo-bactéria}

\subsubsection{Isolados fúngicos utilizados}

Foram utilizados os isolados M131 e C145 de Guignardia citricarpa (Glienke, 1995) e um de Colletotrichum gloeosporioides, isolados como endófitos de folhas de tangerina cravo (Citrus reticulata), tangor murcote $(C$. reticulata $X C$. sinensis) e pétala de laranja doce ( $C$. sinensis) respectivamente. $O$ isolado de $C$. gloeosporioides foi gentilmente cedido pelo pesquisador Carlos I. Aguilar-Vildoso do CCSM.

\subsubsection{Obtenção de metabólitos fúngicos}

Foram inoculados 5 fragmentos de $0,8 \mathrm{~cm}$ de cada colônia fúngica, crescida em meio aveia sólido (item 3.2.6), em erlenmeyr contendo $50 \mathrm{ml}$ de meio aveia líquido (item 3.2.5), e incubados sob agitação $(150 \mathrm{rpm})$ a $28^{\circ} \mathrm{C}$ durante 5 dias. Após o crescimento, centrifugou-se o conteúdo desses frascos a $5000 \mathrm{rpm}(3000 \mathrm{G})$ durante 10 
minutos e coletado o sobrenadante, o qual foi armazenado em refrigerador a $4^{\circ} \mathrm{C}$.

\subsubsection{Ação dos metabólitos fúngicos sobre colônias bacterianas}

Inocularam-se bactérias em $10 \mathrm{ml}$ de meio LB (item 3.2.2), e incubou a $28^{\circ} \mathrm{C}$ por 20 horas a $200 \mathrm{rpm}$. Com auxílio de uma alça de Drigalski, $100 \mu$ l desta cultura foram semeadas sobre $20 \mathrm{ml}$ de meio NA (item 3.2.4). Esperou-se 30 minutos e retirou-se um disco de $0,8 \mathrm{~cm}$ do centro da placa contendo o meio NA, e colocou neste recorte $150 \mu \mathrm{l}$ da solução obtida de acordo com o item 3.6 .2 , e incubou a $28^{\circ} \mathrm{C}$ por 24 horas. Após, foi verificada a ação dos metabólitos fúngicos pela presença ou ausência de halos de inibição ou de estímulo do crescimento bacteriano.

\subsubsection{Verificação da estabilidade térmica dos metabólitos fúngicos}

Os metabólitos fúngicos obtidos de acordo com o item 3.6.2, foram autoclavados a $115^{\circ} \mathrm{C}$ por 20 minutos, e novamente ensaiado o seu efeito sobre o crescimento bacteriano (item 3.6.3).

\subsection{Técnicas moleculares}

\subsubsection{Extração de DNA}

\subsubsection{Extração de DNA total genômico}

As bactérias foram inoculadas em $5 \mathrm{ml}$ de meio LB (item 3.2.2) e incubadas por 60 minutos a $28^{\circ} \mathrm{C}(200 \mathrm{rpm})$. Em seguida $2 \mathrm{ml}$ deste meio foram transferidos para $50 \mathrm{ml}$ de meio LB e a cultura incubada nas condições anteriores por, 20 horas.

Após 0 crescimento, as culturas bacterianas foram centrifugadas por 5 minutos a $5000 \mathrm{rpm}(3000 \mathrm{~g})$, o sobrenadante foi 
desprezado e o precipitado foi lavado em solução salina $(0,85 \%)$ e novamente centrifugado, e tratado como descrito a seguir:

- o precipitado foi ressuspendido em $2 \mathrm{ml}$ de tampão TEN (item 3.3.12)/ lisozima $(4 \mathrm{mg} / \mathrm{ml})$, e em seguida incubado a $37^{\circ} \mathrm{C}$ por 45 minutos,

- foi acrescentado $0,5 \mathrm{ml}$ de solução de $\operatorname{SDS}(8,5 \%)$, e incubou a solução a $75^{\circ} \mathrm{C}$ até clarear (30 minutos), para que ocorresse a lise celular,

- após a lise, foram adicionados $1,5 \mathrm{ml}$ de acetato de potássio $(5 \mathrm{M} ; \mathrm{pH}=5,2)$, e incubo-se em gelo por 20 minutos,

- foram adicionados $4 \mathrm{ml}$ de fenol saturado (item 3.3.6), agitado suavemente por inversão e centrifugado por 10 minutos a 9000 $\operatorname{rpm}(9700 \mathrm{G})$,

- o sobrenadante foi recuperado e a ele foram acrescentados $4 \mathrm{ml}$ de clorofane (item 3.3.10), agitado suavemente por inversão e centrifugado por 10 minutos a $9000 \mathrm{rpm}(9700 \mathrm{G})$,

- o sobrenadante foi novamente recuperado, e neste foram adicionados $4 \mathrm{ml}$ de clorofil (item 3.3.11), foi agitado suavemente por inversão e centrifugado por 10 minutos a $9000 \mathrm{rpm}(9700 \mathrm{G})$,

- foi recuperado o sobrenadante, adicionados $4 \mathrm{ml}$ de isopropanol $4^{\circ} \mathrm{C}$ e incubado a $-20^{\circ} \mathrm{C}$ por 30 minutos para a precipitação do DNA,

- após a incubação, a solução foi centrifugado por 20 minutos a $12000 \mathrm{rpm}(17200 \mathrm{G})$, e posteriormente o precipitado de DNA foi lavado com álcool $70 \%$ gelado e secado a $37^{\circ} \mathrm{C}$ por 30 minutos,

- finalmente o DNA foi ressuspendido em $200 \mu$ de tampão TE (item 3.3.13), e estocado a $-20^{\circ} \mathrm{C}$.

3.7.1.2. Extração de DNA plasmidial (Del Sal et al., 1988).

As bactérias foram inoculadas em $5 \mathrm{ml}$ de meio LB (item 3.2.2), e incubadas a $28^{\circ} \mathrm{C}$ por 20 horas a $200 \mathrm{rpm}$. Após o crescimento, $1,5 \mathrm{ml}$ desta cultura foram coletados em tubos eppendorfs, centrifugado 
$5000 \mathrm{rpm}(418,88 \mathrm{G})$ por 5 minutos. O sobrenadante foi descartado e o precipitado de células ressuspendido em $150 \mu$ lampão STET (item 3.3.15), e tratado como descrito a seguir:

- foram adicionados $5 \mu \mathrm{l}$ de lisozima $(50 \mathrm{mg} / \mathrm{ml})$ e incubado por 5 minutos à temperatura ambiente,

- foi novamente incubado a $95^{\circ} \mathrm{C}$ por 45 segundos e centrifugado a $12000 \mathrm{rpm}(1005,3 \mathrm{G})$ por 10 minutos,

- o precipitado foi retirado com auxílio de um palito de madeira esterilizado, adicionado $8 \mu \mathrm{l}$ de CTAB 5\%, incubou por 5 minutos a temperatura ambiente e centrifugado a $12000 \mathrm{rpm}(1005,3 \mathrm{G})$ por 5 minutos,

- o precipitado foi ressuspendido em $300 \mu \mathrm{l}$ de $\mathrm{NaCl}(1,2 \mathrm{M})$, foi adicionado $750 \mu \mathrm{l}$ de etanol gelado, incubado a $-20^{\circ} \mathrm{C}$ por 20 minutos e centrifugado a $12000 \mathrm{rpm}(1005,3 \mathrm{G})$ por 10 minutos,

-foi lavado o precipitado com etanol $70 \%$, e secado a $37^{\circ} \mathrm{C}$ por 30 minutos. Posteriormente este precipitado foi novamente ressuspendido em $20 \mu$ de tampão TE (item 3.3.13).

\subsubsection{Verificação da integridade do DNA}

A integridade do DNA plasmidial e genômico foi verificada por meio de eletroforese do DNA em gel de agarose 0,8\% (item 3.3.17) a 4 volts $/ \mathrm{cm}$, juntamente com marcador de peso molecular (DNA lambda clivado com Hind III), após a eletroforese, o gel foi corado com brometo de etídio $(1,0 \mu \mathrm{g} / \mathrm{ml})$ e observado em transiluminador de luz ultravioleta. Este método juntamente com a leitura em espectrofotômetro $(260 \mathrm{~nm})^{\text {* }}$ também possibilitou a quantificação do DNA total genômico.

* Spectrofotometer Hitachi U-3300. 


\subsubsection{Verificação do perfil plasmidial}

\subsubsection{Perfil plasmidial}

Após a verificação da integridade do DNA plasmidial (item 3.7.1.3), foi realizado eletroforese em gel de agarose $0,8 \%$ a 3 volts $/ \mathrm{cm}$, durante 3,5 horas, corado com brometo de etídio $(1,0 \mu \mathrm{g} / \mathrm{ml})$, visualizado em transiluminador de luz ultravioleta e fotografado (câmara ZENIT, filme preto e branco Ilford - ASA 50).

\subsubsection{Clivagem do DNA plasmidial}

Em eppendorf foram colocados $20 \mu$ de DNA plamidial, 3,0 $\mu l$ do tampão da enzima, 1,0 $\mu \mathrm{l}$ de enzima de restrição (tabela 3.2) e 6,0 $\mu \mathrm{l}$ de água mili-Q autoclavada. Esta solução foi incubada a $37^{\circ} \mathrm{C}$ por 20 horas.

Após a clivagem, foi realizado eletroforese dos fragmentos em gel de agarose $0,8 \%$ (item 3.3 .17 ) a 3 volts $/ \mathrm{cm}$, seguindo-se a observação após coloração com brometo de etídio $(1,0 \mu \mathrm{g} / \mathrm{ml})$ e fotografia com câmara ZENIT, filme preto e branco llford - ASA 50, sobre transiluminador de luz ultravioleta.

\subsubsection{Análise de polimorfismo gerado por marcadores de RAPD}

3.7.3.1. Amplificação do DNA genômico

Regiōes do DNA genômico foram amplificadas através da técnica de RAPD (PCR com primer arbitrário), em termociclador PerkinElmer-Cetus, programado para realizar uma desnaturação inicial de 4 minutos a $92^{\circ} \mathrm{C}$, seguida de 40 ciclos de 1 minuto a $92^{\circ} \mathrm{C}, 2$ minutos a $37^{\circ} \mathrm{C}, 3$ minutos a $72^{\circ} \mathrm{C}$, e após os ciclos uma extensão final de 3 minutos a $72^{\circ} \mathrm{C}$. A concentração e os componentes utilizados na reação estão listados na tabela 3.3 . 
Tabela 3.2 - Relação de enzimas de restrição e respectivas sequências de reconhecimento.

\begin{tabular}{|c|c|}
\hline Enzima & $\begin{array}{l}\text { Sequência de } \\
\text { reconhecimento }\end{array}$ \\
\hline Sau 3Al & 5'-GATC-3' \\
\hline Hind III & 5'-AAGCTT-3' \\
\hline Xbal & 5'-TCTAGA-3' \\
\hline Eco RI & 5'-GAATTC-3' \\
\hline Kpn I & 5'-GGTACC-3' \\
\hline Xhol & $5^{\prime}-$ CTCGAG-3' $^{\prime}$ \\
\hline Not 1 & $5^{\prime}-$ GCGGCCGC-3' $^{\prime}$ \\
\hline Sfil & $5^{\prime}-\mathrm{GGCCN}_{5}{\mathrm{GGCC}-3^{\prime}}^{\prime}$ \\
\hline
\end{tabular}

Tabela 3.3 - Componentes e respectivas concentrações utilizadas em uma reação de RAPD.

\begin{tabular}{lccc}
\hline \multicolumn{1}{c}{ Componentes } & Estoque & Volume & Concentração final \\
\hline \hline Água (milli-Q estéril) & & $10,7 \mu \mathrm{l}$ & - \\
\hline Tampão (Gibco) & $10 \mathrm{X}$ & $2,5 \mu \mathrm{l}$ & - \\
\hline MgCl2 (Gibco) & $50 \mathrm{mM}$ & $2,0 \mu \mathrm{l}$ & $4,0 \mathrm{mM}$ \\
\hline dNTP & $2,5 \mathrm{mM}$ & $2,0 \mu \mathrm{l}$ & $0,2 \mathrm{mM}$ de cada \\
\hline Primer & $4 \mu \mathrm{M}$ & $2,5 \mu \mathrm{l}$ & $0,4 \mathrm{mM}$ \\
\hline Taq DNA pol. (Cenbiotec) & $5 \mathrm{U} / \mu \mathrm{l}$ & $0,3 \mu \mathrm{l}$ & $1,5 \mathrm{U}$ \\
\hline DNA & $1 \mathrm{ng} / \mu \mathrm{l}$ & $5,0 \mu \mathrm{l}$ & $5,0 \mathrm{ng}$ \\
\hline \hline Total & & $25,0 \mu \mathrm{l}$ & - \\
\hline
\end{tabular}

Os fragmentos amplificados foram separados por eletroforese em gel de agarose 1,4\% (item 3.3.18) a 3 volts $/ \mathrm{cm}$, juntamente com DNA $\lambda$ clivado com Hind III como marcador de peso molecular. Após a eletroforese o gel foi corado em solução de brometo de etídio $(1,0 \mu \mathrm{g} / \mathrm{ml})$ e fotografado (câmara ZENIT, filme preto e branco llford - ASA 50), sobre transiluminador de luz ultravioleta. 
Tabela 3.4 - Lista de "primers" selecionados e respectivas sequências de nucleotídeos.

\begin{tabular}{cccc}
\hline Primer & Sequência & C+G & P.M. \\
\hline OPE-14 & 5'-TCGGGCTGAG-3' & $70 \%$ & 3075 \\
\hline OPE-19 & 5'-ACGGCGTATG-3' & $60 \%$ & 3059 \\
\hline OPE-20 & 5'-AACGGTGACC-3' & $60 \%$ & 3028 \\
\hline OPX-09 & 5'-GGTCTGGTTG-3' & $60 \%$ & 3081 \\
\hline OPX-13 & 5'-ACGGGAGCAA-3' & $60 \%$ & 3077 \\
\hline
\end{tabular}

3.7.3.2. "Primers" selecionados

Os "primers" utilizados foram produzidos pela Operon Technologies (Alameda, CA, EUA) e apresentam sequência de nucleotídeos e peso molecular listados na tabela 3.4.

Estes "primers" foram adquiridos na forma de "pellets" liofilizados. Para o uso foram diluídos em água mili- $Q$ autoclavada para se obter uma concentração estoque de $4 \mu \mathrm{M}$.

3.7.3.3. Construção de dendrogramas

Os dados obtidos por amplificação ao acaso do DNA genômico (RAPD) foram transformados em variáveis binárias, ou seja, 0 número 1 significou presença de banda e o número 0 a ausência de banda, e desta forma foram introduzidos no programa NTSYS-PC (Applied Biostatistics, Inc.). Este programa produziu uma matriz de similaridade com os dados introduzidos, utilizando o coeficiente de similaridade de JACCARD, calculado de acordo com a fórmula:

$$
J=M / P \text {, }
$$

onde $\mathrm{M}$ é o número de concordâncias positivas e $\mathrm{P}$ o número total de variáveis, menos concordâncias negativas. Estes dados da matriz de similaridade, foram então utilizados pelo programa para a construção do dendrograma pelo método de UPGMA. Este dendrograma agrupou os 
diferentes isolados mostrando o nivel de similaridade genética entre os isolados bacterianos. 


\section{RESULTADOS E DISCUSSÃO}

\subsection{Isolamento de Bactérias Endofiticas}

Utilizando a metodologia de isolamento descrita por Pereira (1993) e utilizada por Souza (1996), não foi possível o isolamento de bactérias endofíticas de porta-enxertos de citros, pois, como mostra a figura 4.1 e também constatado por Glienke (1995), a população micótica no interior de folhas de plantas de citros é intensa, inibindo o desenvolvimento de bactérias. Dessa forma, para 0 isolamento de bactérias endofíticas foi necessária a utilização de um agente que promovesse a inibição do crescimento fúngico antes e durante o isolamento. Como citado no item 3.4.1, o fungicida benlate foi utilizado com a finalidade de inibir o crescimento fúngico, antes da desinfecção e durante o isolamento em meio de cultura. Como mostra a figura 4.2, após - tratamento com este fungicida, nenhum crescimento fúngico foi observado a partir dos tecidos foliares.

A figura 4.2 mostra aspectos do isolamento de bactérias endofíticas de explantes foliares de porta-enxertos de citros, após tratamento com benlate. Foram isoladas 530 bactérias numa frequência total de isolamento (FTI) de $73,61 \%$ (tabela 4.1). Não foi observada diferença significativa na frequência de isolamento (FI) entre plantas, entretanto, foi verificada diferença significativa na $\mathrm{FI}$ entre porta-enxertos (figura 4.3 e apêndice 1). Esta diferença ocorreu devido à baixa $\mathrm{FI}$ de endófitos nos porta-enxertos trifoliata limeira e trifoliata kryder, entretanto no teste de tukey, somente trifoliata limeira foi significativamente diferente (tabela 4.1). 

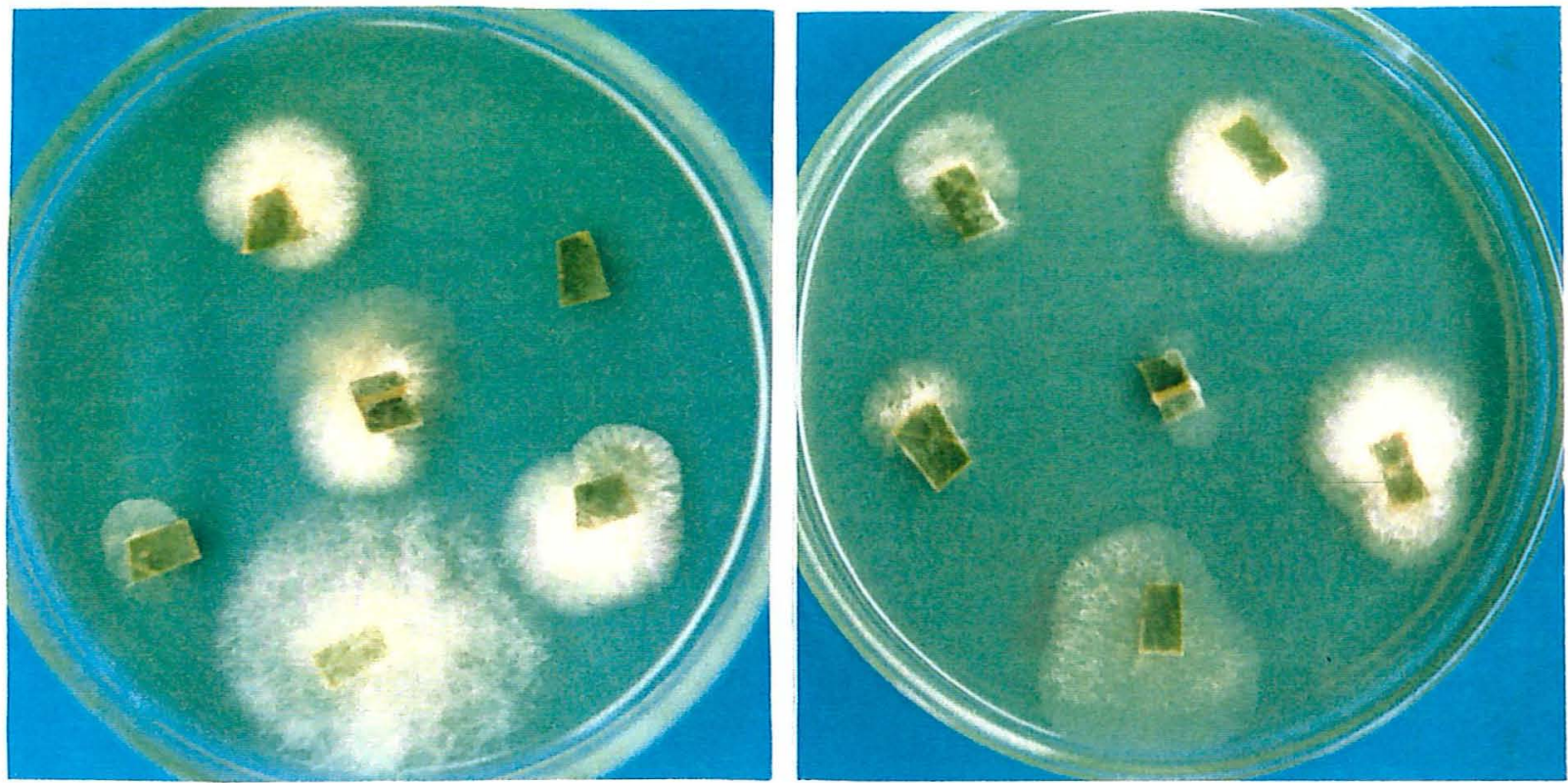

Figura 4.1 - Crescimento de fungos endofíticos a partir de explantes foliares de portaenxertos de citros, após 4 dias de incubação.
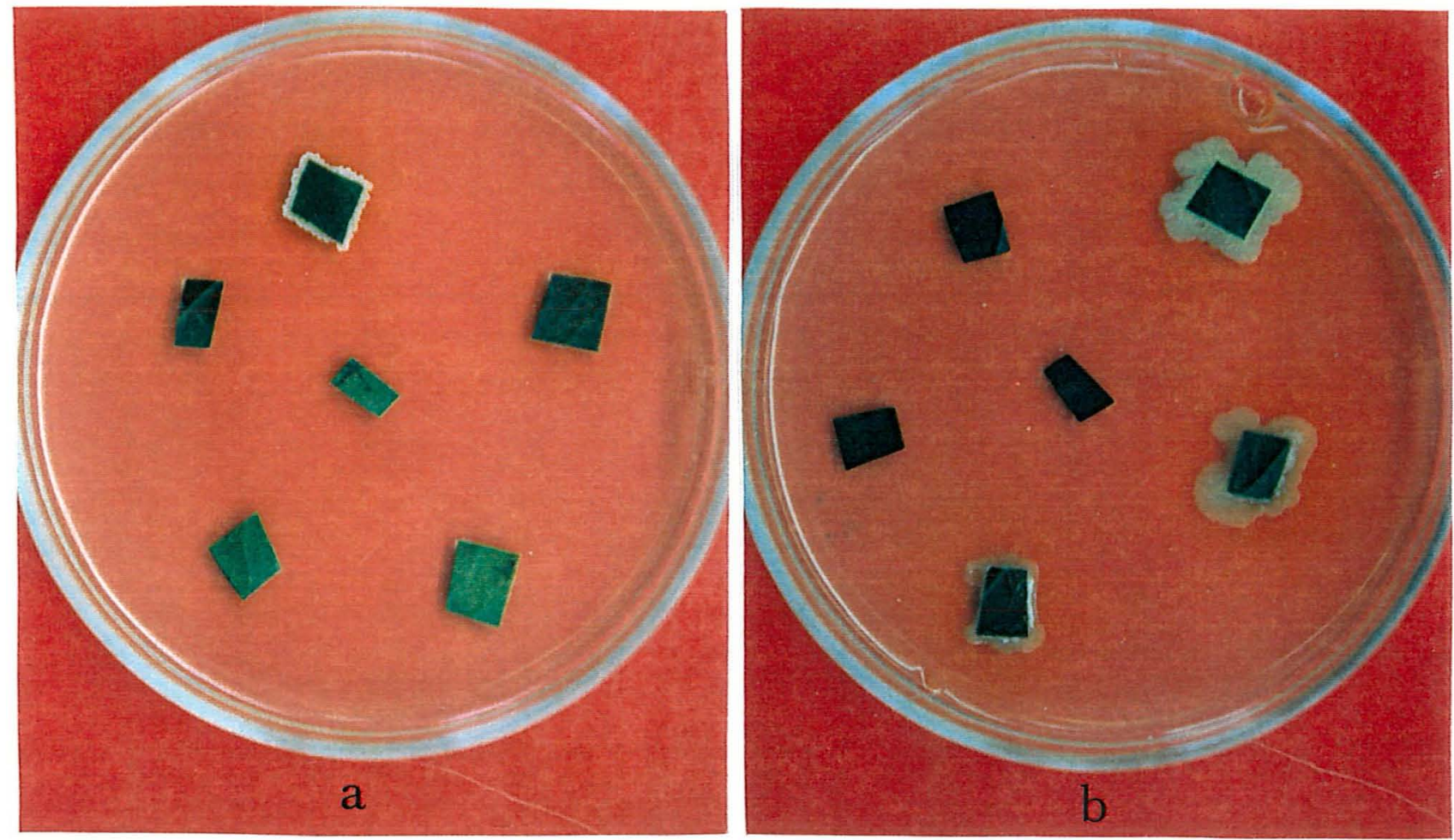

Figura 4.2 - Aspectos do isolamento de bactérias endofíticas de explantes foliares de porta-enxertos de citros. Observar crescimento de bactérias das bordas dos fragmentos foliares, após 24 (a) e 72 horas (b) de incubação. 
Tabela 4.1 - Frequência de isolamento (FI) de bactérias endofíticas de folhas de porta-enxertos de citros.

\begin{tabular}{|c|c|c|c|c|}
\hline & planta $1(\%)^{\star}$ & planta $2(\%)^{*}$ & planta $3(\%)^{*}$ & $(\%)$ total $\left.\right|^{\star \star}$ \\
\hline $\bar{T}$ T. orlando & 100,00 & 100,00 & 91,67 & $97.22 a$ \\
\hline L. C. DAC & 100,00 & 100,00 & 91,67 & $97,22 a$ \\
\hline T. sunki & 91,67 & 66,67 & 100,00 & $86,11 \mathrm{ab}$ \\
\hline L. c. limeira & 91,67 & 91,67 & 75,00 & $86,11 a b$ \\
\hline C. troyer & 91,67 & 75,00 & 83,33 & $83,33 a b$ \\
\hline L. volcameriano & 91,67 & 75,00 & 83,33 & $83,33 a b$ \\
\hline T. cleópatra & 58,33 & 100,00 & 33,33 & $63,89 a b$ \\
\hline L. cravo & 100,00 & 50,00 & 33,33 & $61,11 \mathrm{ab}$ \\
\hline T. kryder & 58,33 & 25,00 & 33,33 & $38,89 a b$ \\
\hline T. limeira & 25,00 & 8,33 & 58,33 & $30,56 \mathrm{~b}$ \\
\hline Total & 83,33 & 69,17 & 68,33 & 73,61 \\
\hline
\end{tabular}

As folhas destes dois porta-enxertos são menores $e$ tripartidas, e por esse motivo, resultam em fragmentos menores quando se eliminam as bordas antes da desinfecção (item 3.4.1). Como são menores, estes fragmentos devem sofrer uma ação mais intensa dos agentes desinfectantes, os quais podem eliminar também os endófitos destas folhas, resultando numa frequência menor de isolamento, causando um erro na frequência.

Utilizando esta metodologia de isolamento de bactérias endofiticas, não foram observadas colônias bacterianas a partir de sementes desinfectadas, sugerindo que estas bactérias isoladas de folhas não são transmitidas via sementes. Como mostrou Glienke (1995), fungos endofíticos de citros também não são transmitidos via sementes, entretanto, Bashan et al. (1982) observaram que Xanthomonas campestris pv. vesicatoria pode colonizar endofiticamente plantas de pimenta e posteriormente, ser transmitida via sementes, porém, estas sementes possuem menos proteção física do que sementes de citros, que apresentam frutos carnosos. 


\subsection{Identificacão Bioquímica dos Isolados Bacterianos}

Devido a impossibilidade de se trabalhar com os 530 isolados, foram tomadas ao acaso, 51 bactérias para identificação. Isso foi feito entre isolados de um mesmo porta-enxerto, permitindo a execução do trabalho com uma amostra da população bacteriana de cada porta-enxerto.

A identificação foi feita por etapas, ou seja, testes bioquímicos foram selecionados para cada grupo de acordo com Sneath et al. (1986), após coloração de Gram. Verificou-se que $64,7 \%$ dos isolados eram gram positivos, e $35,3 \%$ bactérias gram negativas. Os números de bactérias endofíticas gram positivas e negativas por portaenxertos estão listados na tabela 4.2.

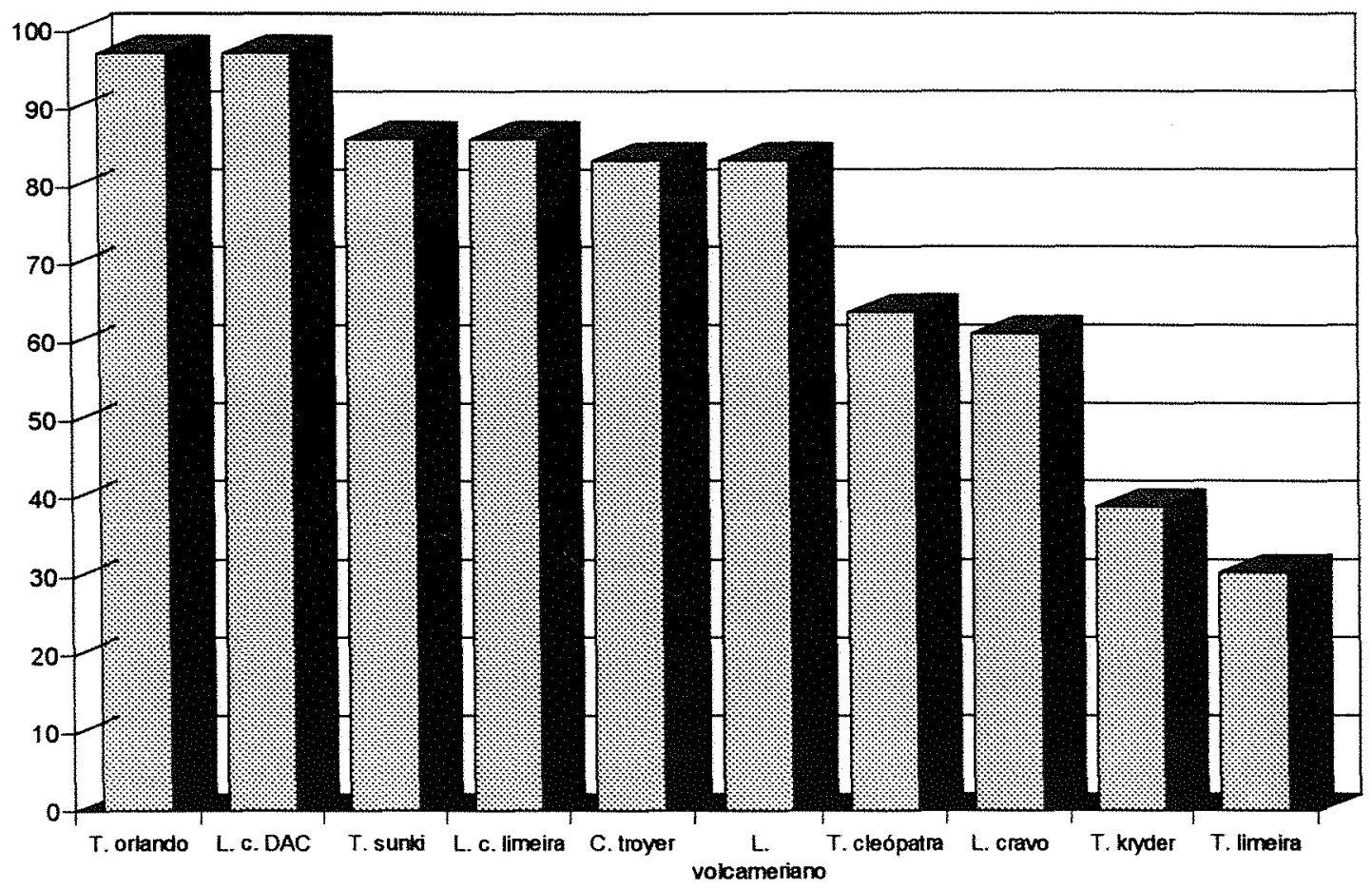

Figura 4.3 - Frequência total de isolamento de bactérias endofíticas de porta enxertos de citros. 
Tabela 4.2 - Distribuição das bactérias gram positivas e gram negativas por portaenxertos.

\begin{tabular}{lcccc}
\hline \multicolumn{1}{c}{ Porta-enxertos } & Código & Gram positivas & Gram negativas & Total \\
\hline \hline T. orlando & TO & 3 & 2 & 5 \\
\hline L. c. DAC & LD & 3 & 2 & 5 \\
\hline T. sunki & TS & 2 & 2 & 4 \\
\hline L. c. limeira & CL & 4 & 1 & 5 \\
\hline C. troyer & CT & 2 & 3 & 5 \\
\hline L. volcameriano & LV & 5 & 2 & 7 \\
\hline T. cleópatra & TC & 2 & 2 & 4 \\
\hline L. cravo & LC & 4 & 2 & 6 \\
\hline T. kryder & CK & 3 & 1 & 4 \\
\hline T. limeira & LT & 5 & 1 & 6 \\
\hline \hline Total & & 33 & 18 & 51 \\
\hline
\end{tabular}

\subsubsection{Bactérias gram positivas}

Os 33 isolados gram positivos foram submetidos aos testes sugeridos por Sneath et al. (1986), listados nas tabelas 4.3 e 4.4. Os resultados obtidos permitiram a identificação de 26 isolados, os quais pertencem ao gênero Bacillus (incluindo $B$. pumilus, $B$. megaterium, $B$. cereus e $B$. lentus) e os 7 isolados restantes foram reunidos de acordo com suas características bioquímicas em dois grupos (tabela 4.4).

O gênero Bacillus já foi descrito como endófito de várias espécies de plantas, entre elas beterraba açucareira (Bugbee et al., 1975; Jacobs et al., 1985), algodão (Misaghi \& Donndelinger, 1990) milho (Fisher et al., 1992; Souza, 1996), e está associado à rizosfera de Lolium perenne (Chanway et al., 1990). No entanto, esses autores não utilizaram métodos de visualização das células bacterianas no interior dos tecidos vegetais e também não discutiram a possibilidade dos esporos produzidos por estas bactérias terem resistido à desinfecção. 


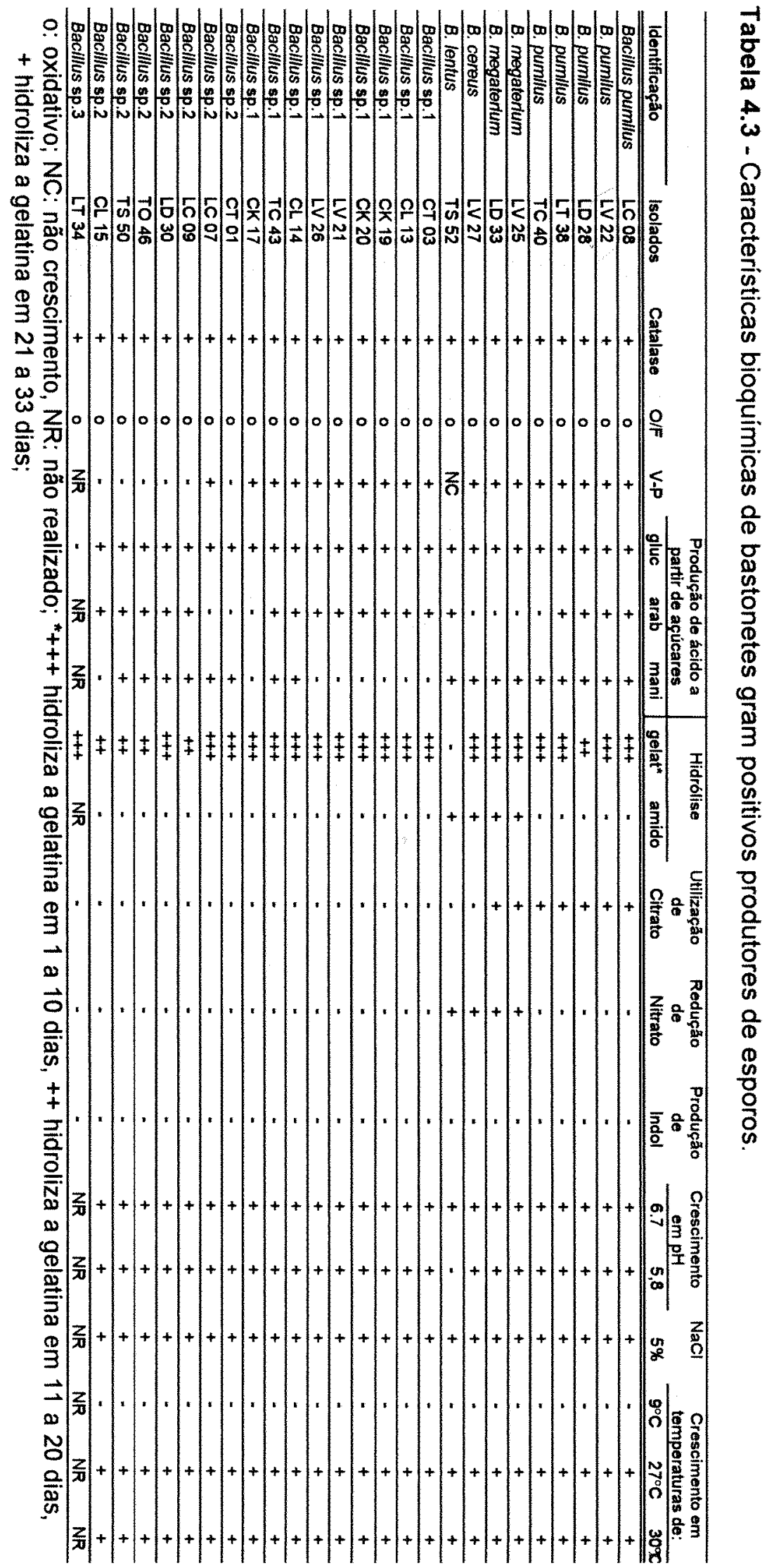




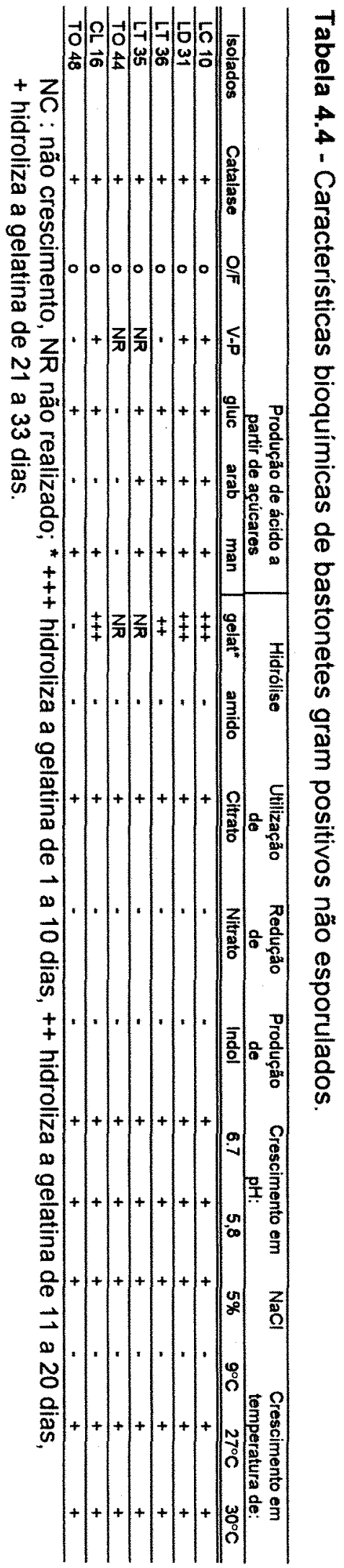


No presente trabalho, foi realizado o teste de vitalidade descrito por Petrini (1984) ${ }^{1}$ citado por Schulz et al. (1993) para verificar se estes Bacillus são endófitos. Os resultados mostraram que os esporos são sensíveis ao tratamento de isolamento utilizado, entretanto, a mudança do substrato (folha de citros para papel de filtro) pode ter colaborado para este resultado. Posteriormente serão discutidos outros resultados que sugerem a possibilidade destes isolados do gênero Bacillus não serem endófitos obrigatórios (verdadeiros).

Os isolados do grupo NI-1 (tabela 4.5) são bioquimicamente semelhantes ao isolados identificados como $B$. pumilus (tabela $4.3 \mathrm{e}$ tabela 4.4), entretanto, esporos não foram visualizados, sugerindo que se trata de isolados desta espécie que perderam a capacidade de esporulação, pois, estas estruturas de resistência não são necessárias para a sobrevivência neste habitat (interior de tecidos vegetais), porém outros estudos como a utilização de microscopia eletrônica e análise molecular destes isolados, devem ser realizados para a confirmação desta hipótese.

Os isolados do grupo N.I.2 não apresentaram semelhança morfológica ou bioquímica com os isolados do gênero Bacillus, e apresentam um crescimento lento quando comparado aos demais grupos.

\subsubsection{Bactérias gram negativas}

A identificação das bactérias gram negativas foi feita por meio dos resultados obtidos com os testes bioquímicos listados na tabela 4.6. Foi verificado que 14 dos 18 isolados gram negativos pertencem ao gênero Erwinia, sendo, provavelmente, todos Erwinia herbicola (sin.: Enterobacer agglomerans), 1 isolado foi identificado como Alcaligenes sp. e 3 isolados não foram identificados (tabela 4.7), entretanto os resultados sugerem que se tratam de bactérias do gênero Pseudomonas.

1 PETRINI, O. Endophytic fungi in British Ericaceae: A preliminary study. Transactions of the British Mycological Society, v.83, p.510-512, 1984. 
Tabela 4.5 - Desdobramento em grupos bioquímicos de bastonetes gram positivos.

\begin{tabular}{lcc}
\hline Identificação & $\mathbf{N}^{\circ}$ de isolados & Porcentagem \\
\hline \hline Bacillus sp. 1 & 9 & 17,65 \\
\hline Bacillus sp. 2 & 7 & 13,73 \\
\hline B. pumilus & 5 & 9,80 \\
\hline B. megaterium & 2 & 3,92 \\
\hline B. lentus & 1 & 1,96 \\
\hline B. cereus & 1 & 1,96 \\
\hline Bacillus sp. 3 & 1 & 1,96 \\
\hline N.I.* 1 & 5 & 9,80 \\
\hline N.I.* 2 & 2 & 3,92 \\
\hline \multicolumn{2}{c}{${ }^{*}$ não identificados }
\end{tabular}

Portanto, como mostra a figura $4.5, E$. herbicola foi a espécie mais frequente neste trabalho. Este resultado confirma estudos anteriores de que esta espécie bacteriana esta frequentemente associada ao filoplano e em inúmeros casos, como já relatado na literatura, encontra-se como endófito (Bugbee et al., 1975; Jacobs et al., 1985; Misaghi \& Donndelinger, 1990; Völksch et al., 1992; Fisher et al., 1992).

Foi verificado também que apenas $E$. herbicola foi isolada de todos os porta-enxertos (tabela 4.8), sugerindo que esta bactéria é um importante endófito de porta-enxertos de citros, onde deve apresentar íntima interação com estas plantas.

Entretanto, o fato destas bactérias não serem isoladas de sementes pode indicar que ou não são sistêmicas ou são específicas para outros tecidos da planta, como folhas, caules etc. Como descrito por Fisher et al. (1992), as bactérias podem apresentar especificidade à regiões do caule próximas ao solo. Trabalhos de microscopia eletrônica poderão auxiliar em investigações posteriores sobre a interação entre estas plantas hospedeiras e suas bactérias endofíticas. 


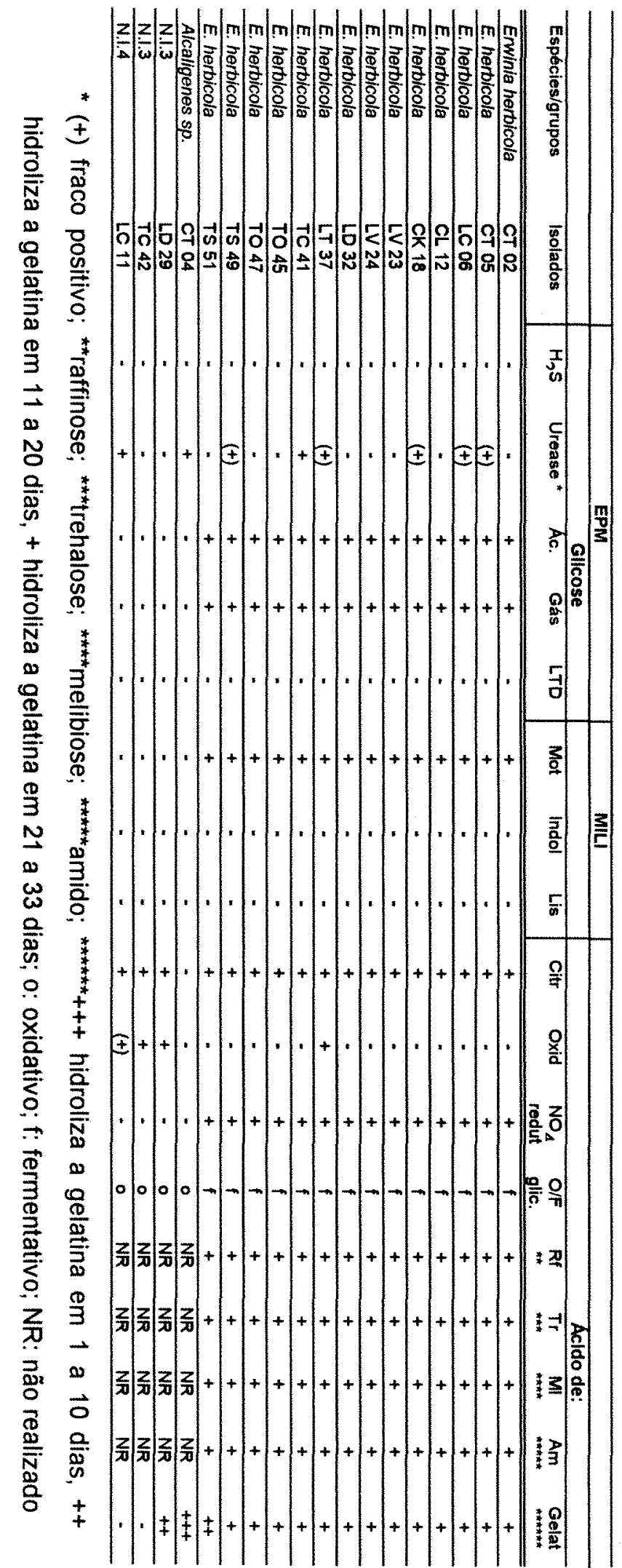

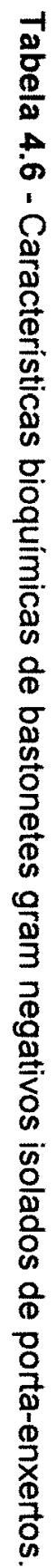


Tabela 4.7 - Desdobramento em grupos bioquímicos de bastonetes gram negativos.

\begin{tabular}{lcc}
\hline \multicolumn{1}{c}{ Identificação } & $\mathbf{N}^{\circ}$ de isolados & Porcentagem \\
\hline \hline Enwinia herbicola & 14 & 24,45 \\
\hline Alcaligenes sp. & 1 & 1,96 \\
\hline N.I.3 & 2 & 3,92 \\
\hline N.I.4 & 1 & 1,96 \\
\hline
\end{tabular}

\subsection{Acão de Metabólitos Fúngicos Sobre Bactérias Endofiticas}

\subsubsection{Bactérias gram positivas}

Como mostra a tabela 4.9 , a maioria das bactérias gram positivas foi inibida pelos metabólitos fúngicos presentes no sobrenadante da cultura. Esta inibição foi observada pela formação de um halo de inibição do crescimento bacteriano em torno do ponto contendo os metabólitos fúngicos (figura 4.6).

Os resultados acima citados, evidenciam a hipótese de que estes microganismos não coexistem no interior da planta hospedeira $e$ que a presença de Bacillus spp. está condicionada à ausência de $G$. citricarpa, pois, a presença deste fungo deve inibir o desenvolvimento da infecção pela bactéria. Esta interação antagônica entre este fungo endofitico e Bacillus spp. reforça a idéia de que estas bactérias devem fazer parte da microbiota epifítica e não endofítica destes hospedeiros.

$O$ isolado de $C$. gloeosporioides inibiu apenas três isolados bacterianos. Esta baixa atividade inibitória pode ter sido observada devido ao fato de que este fungo foi obtido de pétalas, ou seja em outra parte da planta, e em condições normais isolados de C. gloeosporioides obtidos de folhas podem apresentam outras características fisiológicas, que poderiam auxilar na interação deste fungo com microrganismos presente nos tecidos foliares destes hospedeiros.

Portanto, com excessão do isolado TO44 e dos isolados que não sofreram inibição pelos compostos fúngicos, pode-se afirmar que 
estas bactérias são epifiticas de folhas, e que em determinadas condições podem tornar-se endófitos. $O$ isolado TO44 também deve ser um endófito, entretanto devido a baixa frequência de isolamento torna-se difícil aqui uma discussão mais conclusiva. Segundo Petrini (1986), microrganismos epifiticos que eventualmente passam para o interior da planta hospedeira por aberturas como estômatos ou ferimentos, são denominados de endófitos facultativos, ressaltando que esta interação não deve ser tão íntima como aquela existente entre a planta hospedeira e endófitos verdadeiros.

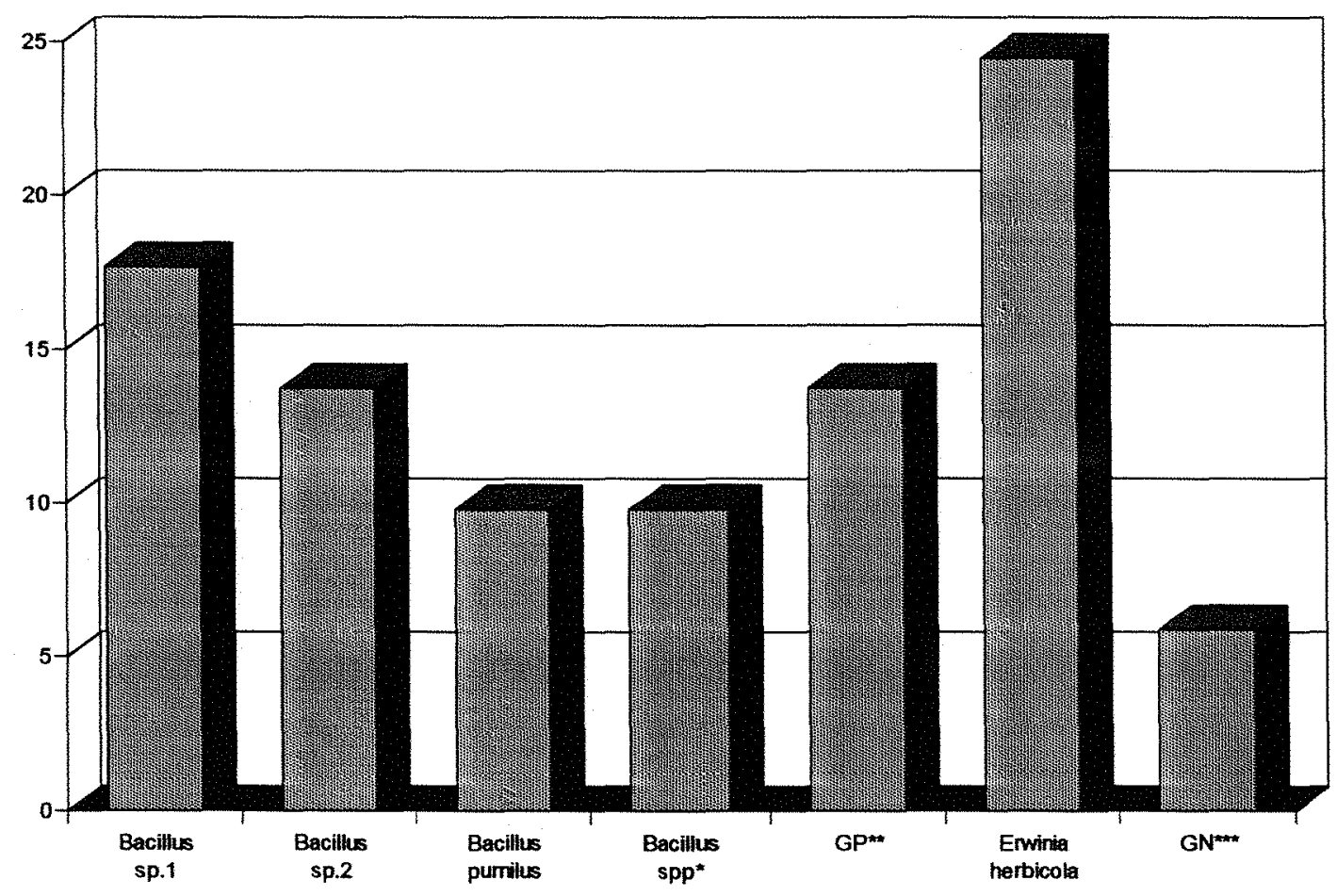

* inclui B. cereus, B. megaterium, B. lentus e Bacillus sp.3;

** isolados gram positivos não identificados;

*** isolados gram negativos não pertencentes ao gênero Enwinia.

Figura 4.4 - Porcentagem dos grupos bacterianos na população total estudada. 
Tabela 4.8 - Isolados bacterianos identificados e seus respectivos hospedeiros.

\begin{tabular}{|c|c|c|}
\hline Porta-enxertos & Código dos isolados & Identificação \\
\hline \multirow{3}{*}{ T. orlando } & TO45; TO47 & E. herbicola \\
\hline & T046 & Bacillus sp. 1 \\
\hline & TO44; TO48 & N.I. \\
\hline \multirow{5}{*}{ L. c. DAC } & LD32 & E. herbicola \\
\hline & LD28 & B. pumilus \\
\hline & LD33 & B. cereus \\
\hline & LD30 & Bacillus sp. 2 \\
\hline & LD29; LD31 & N.I. \\
\hline \multirow{3}{*}{ T. sunki } & TS49; TS51 & E. herbicola \\
\hline & TS52 & B. lentus \\
\hline & TS50 & Bacillus sp. 2 \\
\hline \multirow{4}{*}{ L. c. limeira } & CL12 & E. herbicola \\
\hline & CL13; CL14 & Bacillus sp.1 \\
\hline & CL15 & Bacillus sp.2 \\
\hline & CL16 & N.I. \\
\hline \multirow{4}{*}{ C. troyer } & СT02; СT05 & E. herbicola \\
\hline & CT04 & Alcaligenes sp. \\
\hline & СТ03 & Bacillus sp.1 \\
\hline & СT01 & Bacillus sp.2 \\
\hline \multirow{4}{*}{ L. volcameriano } & LV23; LV24 & E. herbicola \\
\hline & LV25; LV27 & B. megaterium \\
\hline & LV22 & B. pumilus \\
\hline & LV21; LV26 & Bacillus sp. 1 \\
\hline \multirow{4}{*}{ T. cleópatra } & TC41 & E. herbicola \\
\hline & TC40 & B. pumilus \\
\hline & TC43 & Bacillus sp. 1 \\
\hline & TC42 & N.I. \\
\hline \multirow{4}{*}{ L. cravo } & LC06 & E. herbicola \\
\hline & LC08 & B. pumilus \\
\hline & LC07; LC09 & Bacillus sp.2 \\
\hline & LC11 & N.I. \\
\hline \multirow[t]{2}{*}{ T. kryder } & CK18 & E. herbicola \\
\hline & CK17; CK19; CK20 & Bacillus sp.1 \\
\hline \multirow{4}{*}{ T. limeira } & LT37 & E. herbicola \\
\hline & LT38 & B. pumilus \\
\hline & LT34 & Bacillus sp. 3 \\
\hline & LT35; LT36; & N.I. \\
\hline
\end{tabular}


Tabela 4.9 - Ação de metabólitos excretados por fungos endofiticos de plantas cítricas em bactérias endofíticas gram positivas.

\begin{tabular}{|c|c|c|c|c|}
\hline \multirow[t]{2}{*}{ Espécie } & \multirow[t]{2}{*}{ Isolados } & \multicolumn{3}{|c|}{ Metabólitos fúngicos de: } \\
\hline & & M131* & $\mathrm{C} 145^{\star}$ & C. gloeosporioides ${ }^{\star * *}$ \\
\hline B. pumilus & LD28; LV22; TC40; LC08 & - & 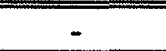 & $--^{* \star \hbar}$ \\
\hline B. pumilus & LT38 & inibição & - & - \\
\hline B. lentus & TS52 & inibição & - & - \\
\hline B. cereus & LD33 & - & - & - \\
\hline B. megaterium & LV25; LV27 & - & - & - \\
\hline Bacillus spp. & CK19 & inibição & inibição & inibição \\
\hline Bacillus spp. & $\begin{array}{c}\text { CL14; LV26; CK17; CK20; } \\
\text { CTO1; LT34 }\end{array}$ & inibição & inibição & - \\
\hline Bacillus spp. & LV21; CL15 & inibição & - & - \\
\hline Bacillus spp. & LD30; TS50; LCO7 & - & inibição & - \\
\hline Bacillus spp. & СТО3 & - & - & inibicão \\
\hline Bacillus spp. & LC09; CL13; TC43; TO46 & - & - & - \\
\hline N.I. & TO44 & estímulo & estímulo & - \\
\hline N.I. & LD31 & inibição & inibição & inibição \\
\hline N.I. & LT35 & inibição & - & - \\
\hline
\end{tabular}

* G. citricarpa; ** $(-)$ : nenhuma alteração no padrão de crescimento bacteriano foi observado. ${ }^{\star \star \star}$ isolado de pétalas de laranja doce.

\subsubsection{Bactérias gram negativas}

A ação dos metabólitos fúngicos sobre bactérias endofíticas gram negativas foi verificada como descrito no item 3.6. Observou-se que C. gloeosporioides isolado de pétalas de laranja doce ( $C$. sinensis) não produziu qualquer composto que afetasse de alguma maneira o crescimento dos isolados bacterianos gram negativos (tabela 4.10). Souza (1996), verificou resultado semelhante entre Penicillium spp. e Bacillus spp., endófitos de milho. O autor sugeriu que esta neutralidade confirma a presença simultânea destes microrganismos no interior da planta hospedeira. Dessa forma, é possível sugerir que tanto $C$. gloeosporioides como estas bactérias gram negativas endofiticas isoladas no presente trabalho devem coexistir no interior dos tecidos vegetais destas plantas. 
Por outro lado, os isolados de G. citricarpa isolados de folhas de Citrus spp., produziram compostos que estimularam o crescimento da maioria das bactérias gram negativas (tabela 4.10 e figura 4.6), mostrando a existência de uma associação benéfica entre estas bactérias e estes fungos, com vantagem para as bactérias.

Todos os isolados de E. herbicola foram estimulados a crescerem quando na presença do sobrenadante de cultura do isolado C145, enquanto que os metabólitos excretados pelo isolado M131 estimulou apenas $78,5 \%$ das bactérias desta espécie. Os resultados indicam que estes microrganismos podem coexistir no interior da planta e que a infecção do hospedeiro por $E$. herbicola pode ser estimulada pela presença de G. citricarpa.

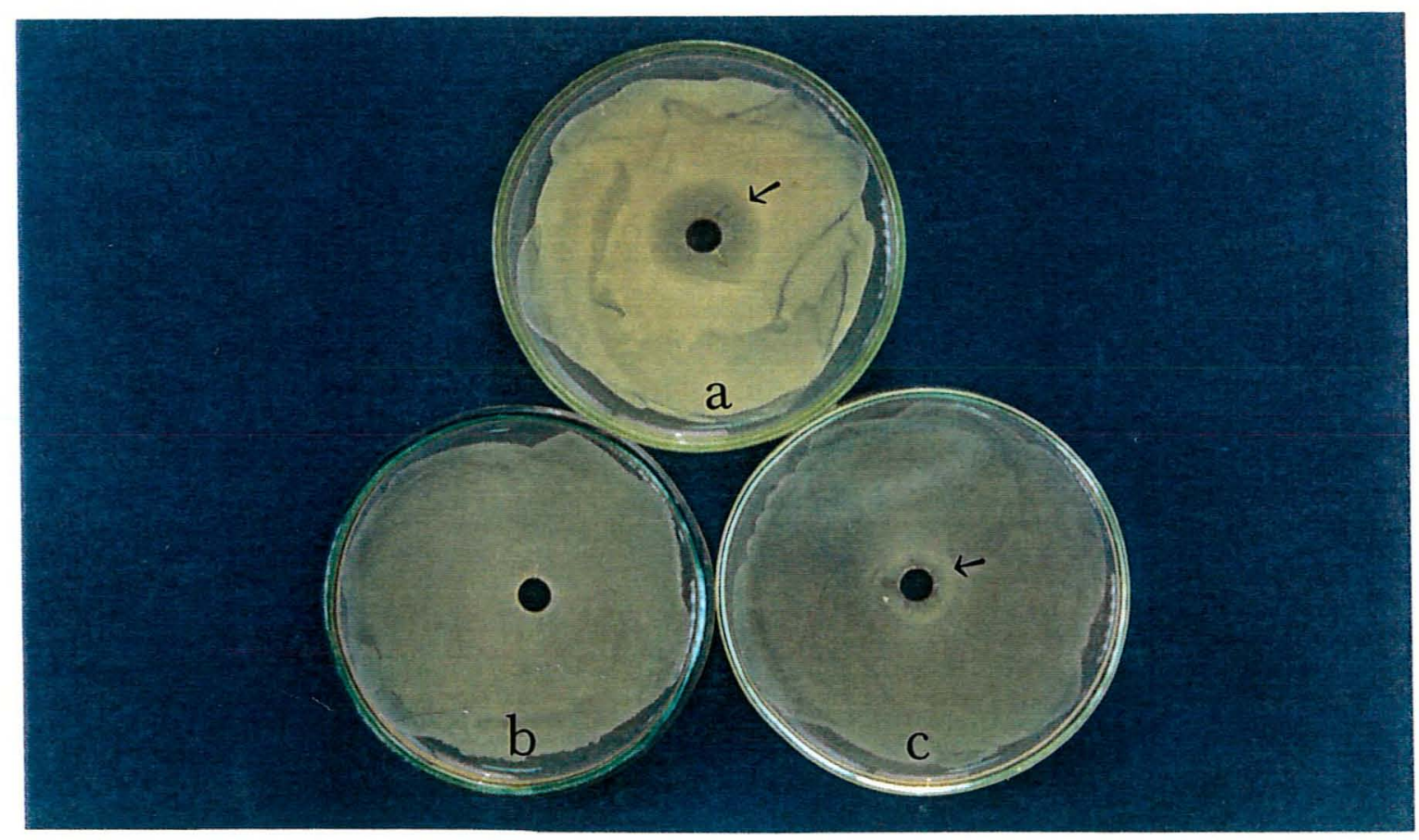

Figura 4.5 - Aspecto do crescimento bacteriano na presença dos metabólitos fúngicos: a)Bacillus sp. com halo de inibição, devido a ação de metabólitos do isolado M131 de G. citricarpa; b)E. herbicola com crescimento normal; c)E. herbicola com halo de crescimento estimulado por metabólitos produzidos pelo isolado M131 de G. citricarpa. 
Tabela 4.10 - Ação de metabólitos excretados por fungos endofíticos de plantas cítricas sobre bactérias endofíticas gram negativas.

\begin{tabular}{|c|c|c|c|c|}
\hline \multirow[t]{2}{*}{ Espécie } & \multirow[t]{2}{*}{ Isolados } & \multicolumn{3}{|c|}{ Metabólitos fúngicos de: } \\
\hline & & $M 131^{\star}$ & $\mathrm{C} 145^{\star}$ & Colletotrichum sp. \\
\hline E. herbicola & $\begin{array}{l}\text { CTO2; CTO5; CL12; CK18; } \\
\text { CK23; LV24; LT37; TC41; } \\
\text { TO45; TS49; TS51 }\end{array}$ & estimulo & estímulo & $--^{\star \star}$ \\
\hline E. herbicola & LC06; LD32; TO47 & - & estímulo & - \\
\hline Alcaligenes sp. & CTO4 & - & - & - \\
\hline N.I.3 & LD29; TC42 & - & - & - \\
\hline N.I.4 & LC11 & - & estímulo & - \\
\hline
\end{tabular}

Outros estudos devem ser realizados para se entender melhor esta interação, pois, além da associação entre estes microrganismos endofíticos devem haver outros mecanismos regulatórios e/ou responsáveis pela manutenção destes endófitos no interior da planta.

\subsubsection{Termoestabilidade dos metabólitos fúngicos.}

Com o objetivo de se fazer um estudo qualitativo dos metabólitos fúngicos, que apresentaram a capacidade de inibir ou estimular 0 crescimento de diferentes isolados bacterianos, estes metabólitos foram tratados como descrito no item 3.6.4.

Foi verificado que os metabólitos fúngicos tiveram a mesma atuação sobre os isolados bacterianos após o tratamento térmico. Este resultado, juntamente com 0 fato de que estes compostos são rapidamente difundidos no meio, sugerem que se trata de uma molécula pequena e termoestável, provavelmente um mono ou oligossacarídeo. Entretanto, para confirmar esta hipótese, estudos de cromatografia devem ser realizados para se verificar a natureza e propriedades químicas destes compostos. Posteriormente, estes metabólitos poderão 
ser utilizados para inibir ou estimular infecções em plantas de interesse, por bactérias patogênicas ou endofíticas respectivamente.

\subsection{Variabilidade Genética por RAPD}

\subsubsection{Padronização da técnica e escolha dos "primers"}

Para a padronização da reação de RAPD, foi escolhido ao acaso DNA do isolado CK17, o qual foi submetido a ensaios de concentração de DNA e $\mathrm{MgCl}_{2}$, e após esta padronização foi feita a escolha dos "primers" capazes de amplificar o DNA genômico dos isolados endofíticos.

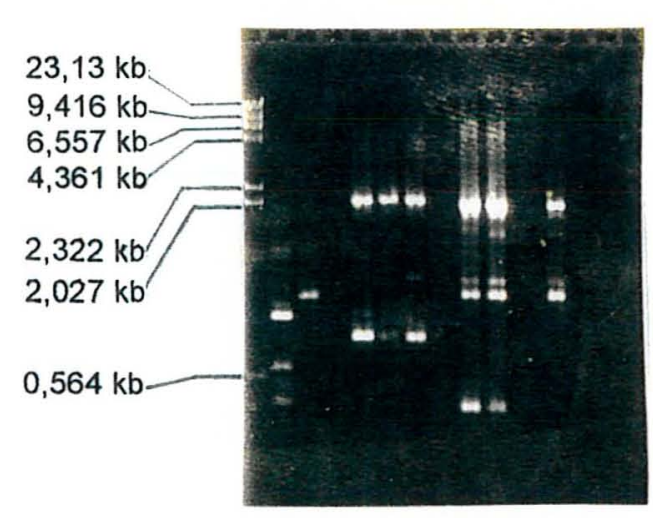

Figura 4.6 - Padrão de bandas obtidos no ensaio para ajuste da concentração de DNA com os "primers" (b)OPX04; (c)OPX09; (d)OPX14 e (e)OPX10. As concentrações utilizadas foram: 1)5,0 ng; 2)2,5 ng; 3)10 ng. (a)marcador de peso molecular (DNA $\lambda$ clivado com Hind III) - (" concentração de taq DNA polimerase alterada). 
Foram ensaiadas concentrações de 10,20,40, 80 e $100 \mathrm{ng}$ de DNA genômico para $25 \mu \mathrm{l}$ de reação, utilizando isoladamente 4 "primers". Estas concentrações foram escolhidas pois Williams et al. (1990) obteve produtos de amplificação de diferentes DNAs bacterianos utilizando $25 \mathrm{ng}$ de DNA genômico por reação. Entretanto, no presente trabalho nenhum produto de amplificação foi observado nestas condições.

Dentro deste contexto, verificou-se que inúmeros autores obtinham produtos de amplificação em bactérias com concentrações menores que $10 \mathrm{ng}$ de DNA (Welsh et al., 1990; Sandery et al., 1994; Farber \& Addison, 1994), e por esse motivo foram ensaiadas concentraçōes menores $(2,5 ; 5,0$ e $10 \mathrm{ng})$ de DNA genômico por reação. Este ensaio permitiu verificar que o espectro de concentração de DNA em bactérias é baixo, sendo $5,0 \mathrm{ng}$ de DNA por reação a quantidade ideal para se observar um número maior de bandas com os 4 "primers" utilizados (figura 4.6).

Também foram ensaiadas diferentes concentrações de $\mathrm{MgCl}_{2}\left(2,0 ; 3,0 ; 4,0 ; 5,0\right.$ e $7,0 \mathrm{mM}$ de $\mathrm{MgCl}_{2}$ por reação). Os resultados mostraram que 4,0 mM de $\mathrm{MgCl}_{2}$ foi a melhor concentração para se obter bandas claras e nítidas. Após a padronização, as condições foram determinadas (ver tabela 3.3 do material e métodos) e partiu-se para a escolha dos melhores "primers", os quais deveriam produzir bandas fortes e bem definidas que permitissem posteriormente a visualização de polimorfismo entre os isolados estudados. Com essa finalidade, foram ensaiados 20 "primers" do Kit OPE e 20 "primers" do KIT OPX, produzidos pela Operon Technologies, e destes foram escolhidos inicialmente 10 "primers". Entretanto, apenas 5 destes oligonucleotideos foram utilizados no presente trabalho (ver tabela 3.4 do materiais $e$ métodos).

De acordo com Williams et al. (1990), os oligonucleotídeos iniciadores utilizados na reação de RAPD desempenham importante função na amplificação do DNA alvo, pois verificou-se que a mudança de um único nucleotídeo na sequência pode alterar todo o padrão de 
bandas, provavelmente por alterar o sitio de homologia do "primer" com o DNA molde. Estes autores também verificaram que "primers" muito pequenos (menos de nove nucleotídeos) não produzem fragmentos de amplificação. Entretanto observou-se que "primers" maiores, de até 20 nucleotídeos, são capazes de amplificar DNA genômico de diferentes bactérias (Welsh et al., 1990).

\subsubsection{Verificação de polimorfismo por RAPD}

Para a verificação da variabilidade existente entre os isolados bacterianos estudados, foi extraído DNA (item 3.7.1.1) de 34 isolados, escolhidos aleatoriamente entre os 51 isolados identificados. Estes DNAs foram amplificados com auxilio dos "primers", listados na tabela 3.4, permitindo por meio de marcadores de RAPD se verificar as relações genéticas entre estes isolados.

A técnica de RAPD por ter a propriedade de se detectar variabilidade entre indivíduos muito semelhantes, pode ser utilizada para distinguir isolados adaptados a diferentes locais, ou linhagens patogênicas das não patogênicas. Esta distinção é viável, pois, para que ocorra adaptação a um habitat específico, pode ser aventado que conjuntos de genes devem ser selecionados, os quais, após análise, geram polimorfismo.

Dentro deste contexto, Manulis et al. (1994), por meio de análise via marcadores de RAPD conseguiram distinguir isolados fitopatogênicos de Fusarium oxysporum f. sp. dianthi de isolados não patogênicos de cravo. Da mesma forma, Farber \& Addison (1994), discriminaram linhagens patogênicas das não patogênicas de Listeria spp. Estes resultados mostram a importância da utilização do RAPD para a análise de variabilidade. Portanto esta técnica se mostra como uma boa alternativa para vários estudos na área de microbiologia, porém o RAPD não deverá substituir as demais metodologias utilizadas atualmente na biologia molecular (Loureiro, 1994), mas, com estas técnicas 
moleculares, o RAPD poderá aumentar o número de informações a respeito das relações genéticas entre diferentes grupos.

No presente trabalho, os 5 "primers" utilizados produziram 110 bandas polimórficas, ou seja, estas bandas estiveram presentes ou ausentes em pelo menos um isolado. O número médio de bandas por "primer" foi de 22, entretanto o decaoligonucleotídeo OPX09 produziu apenas 7 bandas, das quais uma de $2,027 \mathrm{~kb}$ esteve presente em 30 dos 34 isolados (figura 4.7).

A análise conjunta dos 5 "primers" permitiu a construção de uma matriz de similaridade, por meio do coeficiente de JACCARD (item 3.7.3.3), e posteriormente a elaboração de um dendrograma (figura 4.8) a partir desta matriz, através do método de UPGMA.

É possivel verificar no dendrograma (figura 4.8) que as bactérias analisadas via marcadores de RAPD formaram um grupo muito similar constituído por 9 isolados identificados como $E$. herbicola e vários outros grupos com pouca similaridade. Este grupo de $E$. herbicola apresentou um coeficiente de similariedade (cs) médio de $87,5 \%$, e compartilhou apenas $8 \%$ do total de bandas com os demais isolados, mostrando alta divergência entre este e os demais grupos.

Dentro deste grupo de $E$. herbicola, verificou-se que os isolados LV24 e LT37, obtidos respectivamente de limão volcameriano e trifoliata limeira, foram os mais similares, pois, apresentaram um coeficiente de dissimilaridade (1-cs) de apenas $2 \%$. Já o isolado TO45 foi o mais distinto do grupo, com um coeficiente de dissimilaridade de $23 \%$ em relação aos demais isolados. Verificou-se também que se for traçado uma linha imaginária ao nível de $85 \%$ de similaridade $(15 \%$ de dissimilaridade) neste grupo de $E$. herbicola, os isolados se agrupam dois a dois, independente do porta-enxerto de origem (comparar figura 4.10 com tabela 4.8), pois os isolados LV23 e LV24 foram obtidos do mesmo porta-enxerto, e apresentam um coeficiente de dissimilaridade de $14 \%$, maior do que o observado entre os isolados LV23 e LD32 e os isolados LV24 e LT37 que são dissimilares 8 e $2 \%$ respectivamente. 

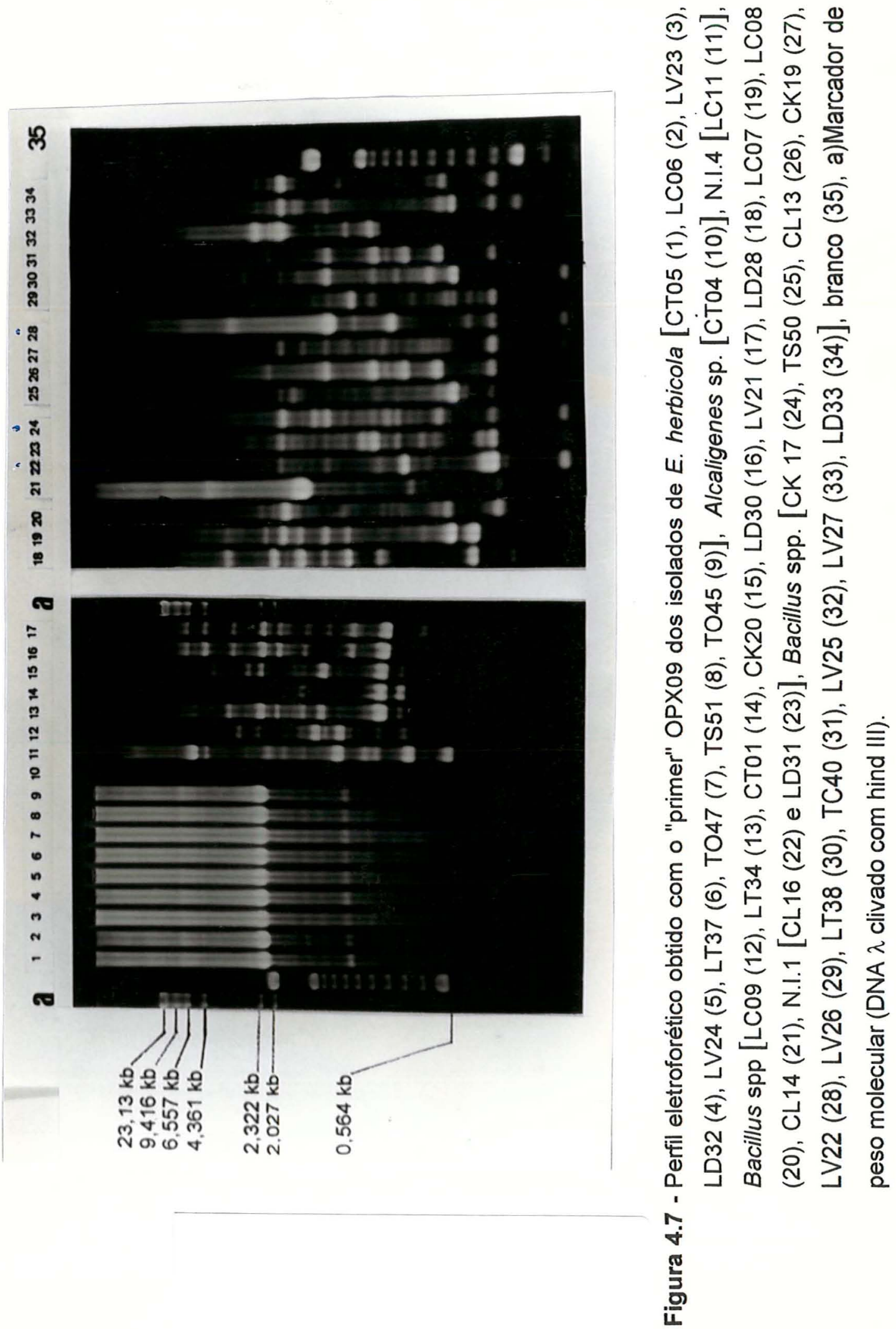


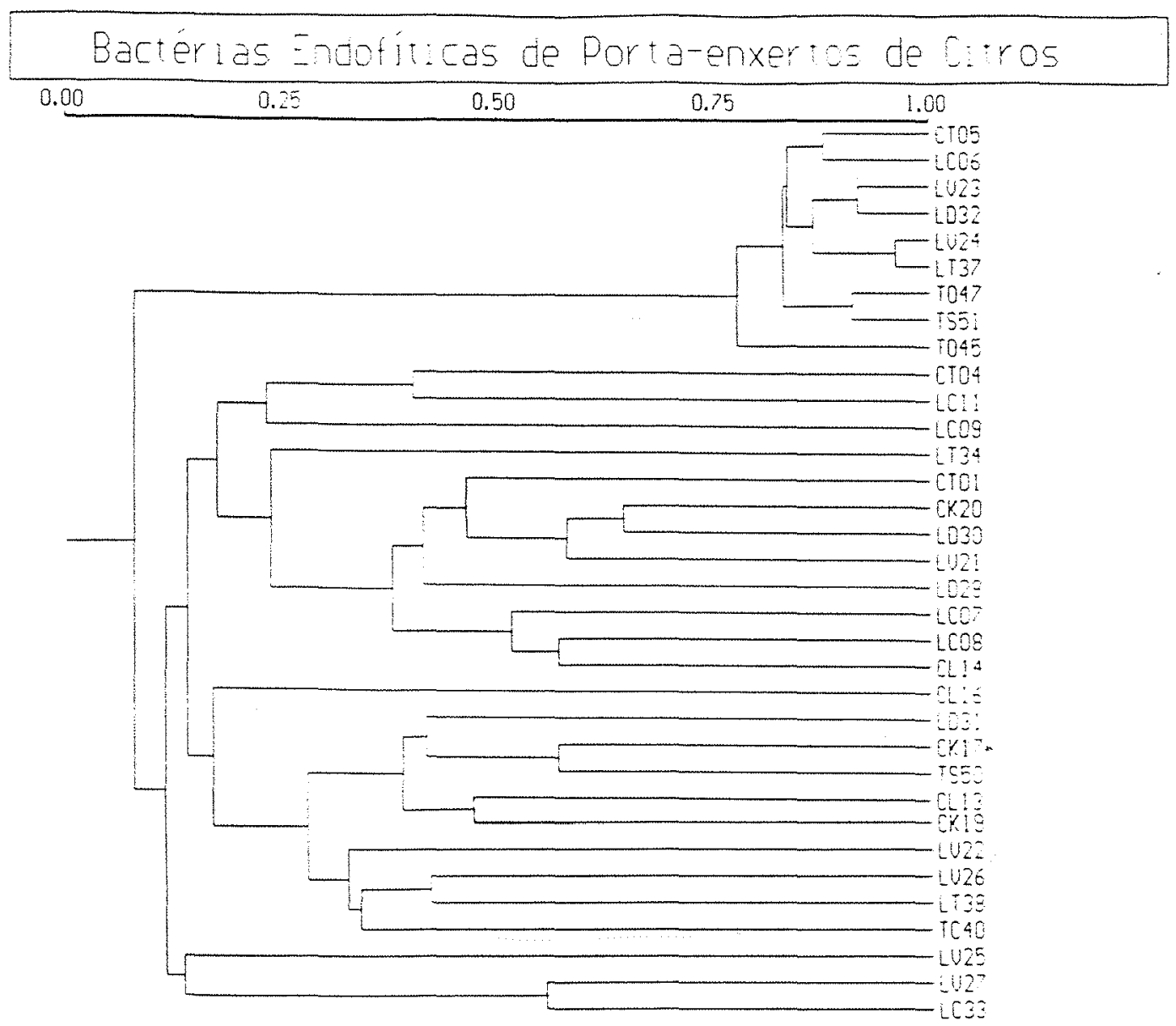

Figura 4.8 - Dendrograma obtido a partir de uma matriz de similaridade genética entre os isolados endofíticos de porta-enxertos de citros. Para a construção da matriz, foi utilizado o coeficiente de JACCARD.

Estes dados mostram que não deve ocorrer especificidade dos genótipos bacterianos a porta-enxertos específicos, entretanto a baixa divergência genética verificada neste grupo, sugere que estes isolados endofiticos tenham mantido esta informação genética devido à especificidade ao habitat. Caballero-Mellado \& Martinez-Romero (1994), também sugeriram que a baixa divergência genética verificada em isolados endofiticos de $A$. diazotrophicus, por meio de marcadores isoenzimáticos, perfil plasmidial e DNA "fingerprints" é devido a adaptação destes isolados à ambientes específicos, como o interior do caule de cana-de açúcar. Outros autores como Falkenstein et al. (1988) e Coplin 
(1989) também citam que plasmídios e sequências altamente conservadas em bactérias coevoluíram com seus hospedeiros, e por esse motivo se mantêm estáveis nestes procariotos.

Os resultados obtidos com os DNAs extraidos de bactérias do gênero Bacillus, juntamente com os isolados não identificados CL16, LD31, LC11 e Alcaligenes sp., mostraram que ocorre uma alta divergência genética entre estes isolados, independentemente da origem e da espécie utilizada. O dendrograma obtido dos resultados, mostra que os isolados mais similares são CK20 e LD30, que apresentaram um coeficiente de similaridade em torno de $65 \%$, entretanto o coeficiente de similaridade médio do grupo foi de $38,5 \%$, ou seja, muito inferior ao observado entre os isolados de $E$. herbicola.

O baixo coeficiente de similaridade observado entre estes isolados acima citado, mostra que esta divergência genética ocorreu independentemente da origem $e$ das características bioquímicas utilizadas para identificação, pois os isolados CK19 e CK20, obtidos de trifoliata limeira (tabela 4.8) apresentam características bioquímicas idênticas (tabela 4.3), mas compartilham apenas $14 \%$ das bandas geradas por RAPD e analisadas no presente trabalho, como mostra o resultado obtido com o "primer" OPE14 (figura 4.9). Estes resultados sugerem que as regiōes do genoma destes indivíduos amplificados por RAPD, não devem sofrer uma forte pressão de seleção, pois, esta alta divergência não se expressou nas características fisiológicas observadas por meio da análise bioquímica.

Esta alta variabilidade verificada no gênero Bacillus, isolado de plantas, também foi constatada por Souza (1986). Este autor analisou 13 isolados de diferentes plantas de milho em locais distintos. Este resultado juntamente com os obtidos no presente trabalho, reforçam a hipótese de que bactérias do gênero Bacillus devem ser epifitas ou endófitas facultativas, ou seja não apresentam íntima associação com a planta hospedeira. Entretanto, sua presença pode indicar que elas possam ser utilizadas como antagonistas a patógenos que inicialmente colonizam a superfície da planta antes da infecção. 


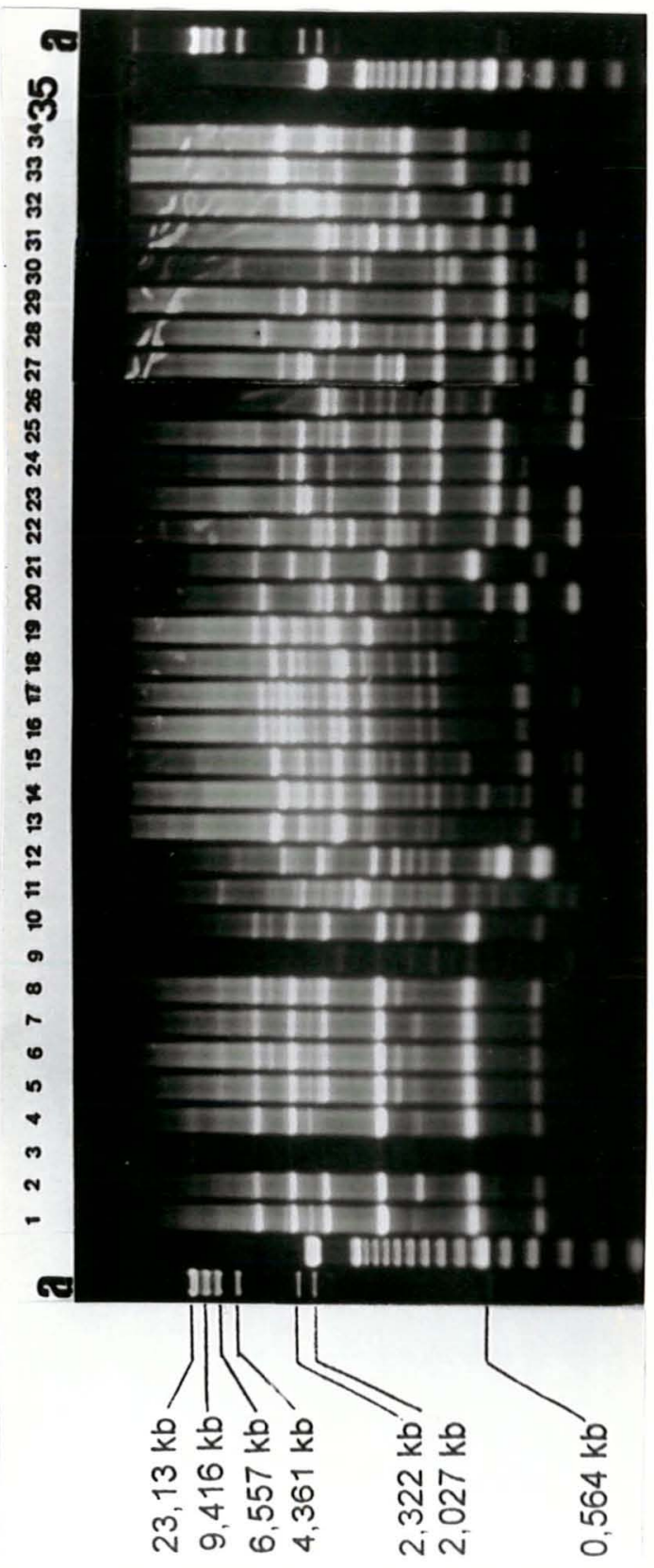

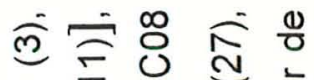

लㄷำ

\宁宁

बิ山

过芒过

U z

-

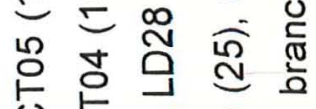

U U

응

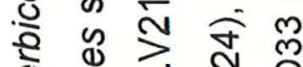

ฐ

山i

웡 잉

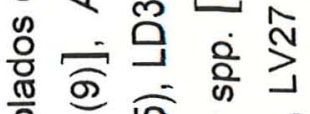

은

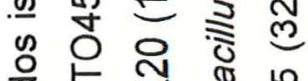

穴

㟧家

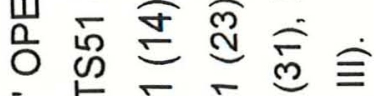

㐫它它宁守

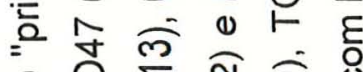

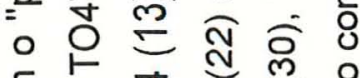

हैं

응 㲾吉点

。气

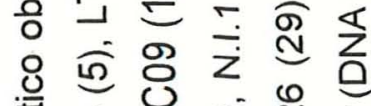

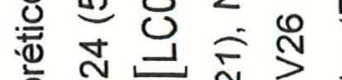

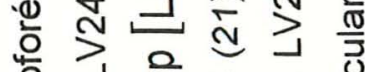

"긍 응

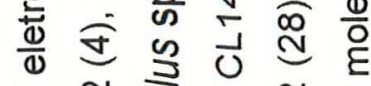

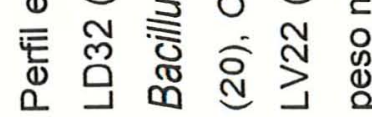

gु

$\dot{8}$

휸 
A divergência observada entre o agrupamento feito com os testes bioquímicos e o obtido por meio dos marcadores de RAPD, mostra que a metodologia atualmente utilizada para classificação e posterior identificação de bactérias não é totalmente concordante, pois, delega pouca importância à técnicas moleculares.

Entretanto, devemos ressaltar que o número de testes bioquimicos utilizados neste trabalho foi pequeno, sendo talvez necessário um número maior de testes bioquímicos para um agrupamento mais adequado. Portanto, quando técnicas de genética molecular como hibridização DNARNA e DNAVDNA, RFLP, PCR e RAPD entre outras, forem utilizadas juntamente com características bioquímicas, talvez seja possivel elaborar uma classificação adequada e consistente dos diferentes taxons bacterianos.

\subsection{Perfil plasmidial}

Após a extração do DNA total dos isolados bacterianos, foi verificado em eletroforese em gel de agarose a presença de DNA plasmidial nas amostras. Os isolados analizados apresentaram de 0 a 5 bandas. Quando presentes, migraram no gel mais que 0 DNA cromossômico.

Para se realizar um estudo mais detalhado foi feito um a extração de DNA plasmidial (item 3.7.1.2) dos isolados gram negativos e do isolado LT34 (Bacillus sp.).

Observou-se que os isolados CTO4 (Alcaligenes sp), LC11, LD29 E LT34 não apresentaram plasmidios nestas condições. $O$ isolado TC42 apresentou um plasmídio, enquanto que os isolados de $E$. herbicola apresentaram várias bandas plasmidiais (figura 4.10). Com exceção do isolado CL12, todos os isolados de $E$. herbicola apresentaram o mesmo perfil plasmidial, embora o número e o tamanho desses plasmídios não puderam ser verificados neste gel. 


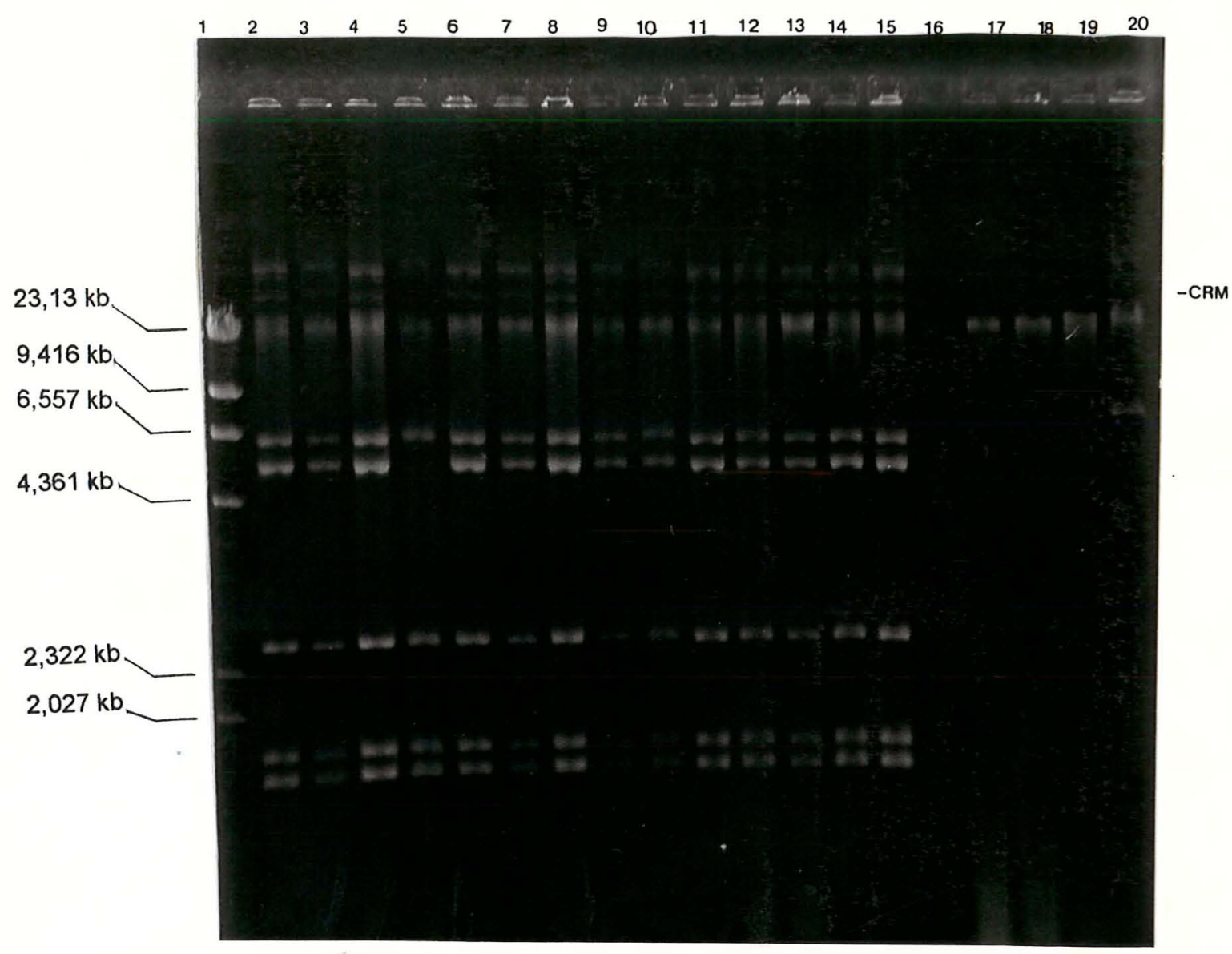

Figura 4.10 - Padrão de bandas plasmidiais não clivadas, obtidas após extração. 1)marcador de peso molecular (DNA $\lambda$ clivado com hind III), 2)CT02, 3)CT05, 4)LC06, 5)CL12, 6)CK18, 7)LV23, 8)LV24, 9)LD32, 10)LT37, 11)TC41, 12)TO45, 13)TO47, 14)TS49, 15)TS51, 16)CT04, 17)LC11, 18)LD29, 19)LT34, 20)TC42; CRM (DNA cromossômico)

Com o objetivo de se determinar o número e o tamanho dos plasmídios presentes em $E$. herbicola, foi realizada uma reação de digestão (item 3.7.2.2) com o DNA plasmidial do isolados CK18 com 8 enzimas de restrição (tabela 3.2 ). O resultado obtido não pemitiu determinar o número e o tamanho dos plasmídios (figura 4.11a), mas pode-se sugerir que devam existir 2 ou 3 plasmídios distintos nestes isolados. 

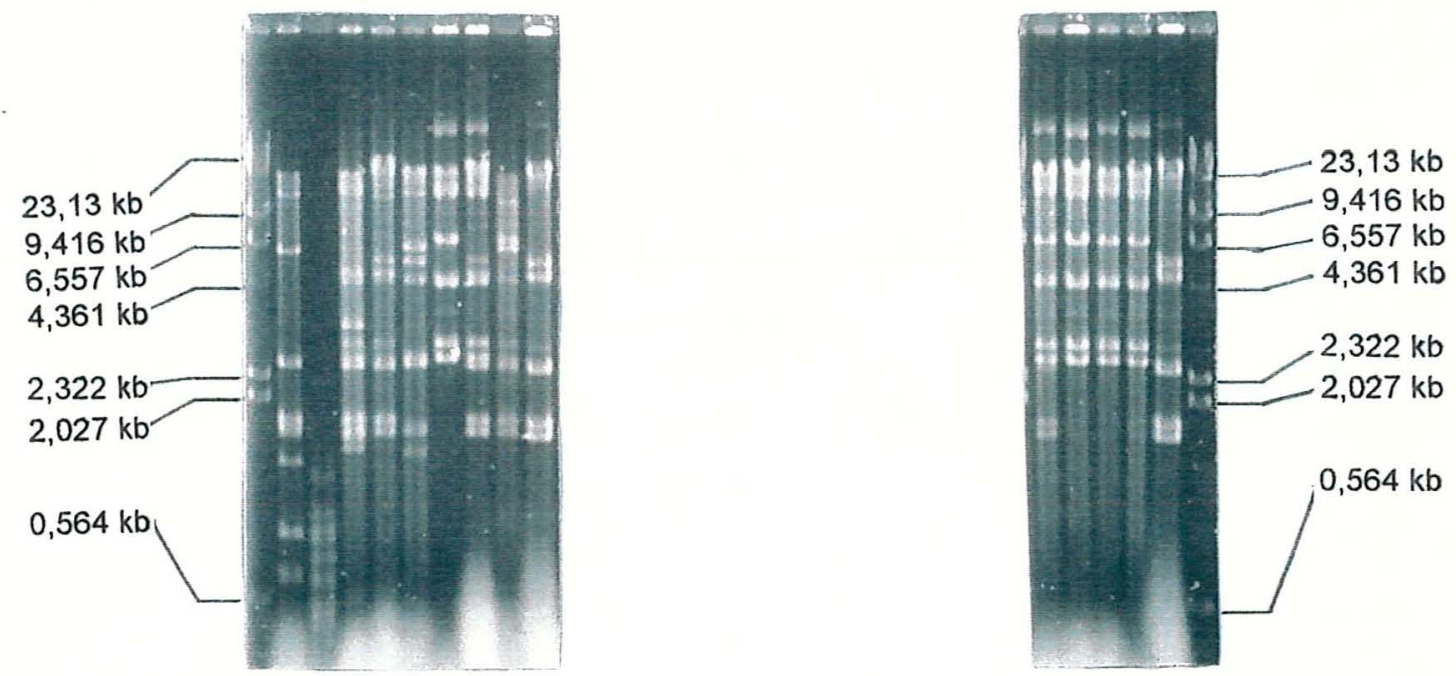

Figura 4.11 - Perfil de bandas obtidos após clivagem de DNA plasmidial. a)DNA plasmidial do isolado CK18 clivado com diferentes enzimas de restrição. 1)marcador de peso molecular (DNA $\lambda$ clivado com hind III), 2)Hind III, 3)Sau 3AI, 4)Kpn I, 5)Xba 1, 6)Xho I, 7)Not I, 8)Sfi I, 9)Eco RI, 10)DNA plasmidial não clivado; b)DNA plasmidial de diferentes isolados clivados com Not I: 1)LC06, 2)LCK18, 3)LD32, 4)TO47, 5)DNA plasmidial não clivado, 6)marcador de peso molecular (DNA $\lambda$ clivado com hind III).

A digestão do DNA plasmidial dos isolados LC06, CK18, LD32 e TO47 com a enzima de restrição Not I (figura 4.11b), permitiu a 
verificação de que entre estes isolados não ocorre variabilidade no sítio de restrição desta enzima, pois o perfil plasmidial foi idêntico para os 4 isolados, com exceção do isolado LC06 que manteve duas bandas na região inferior do gel, semelhante a duas bandas do DNA não clivado do isolado CK18, sugerindo que estas bandas presentes no DNA deste isolado, tratado com a enzima Not I seja DNA não clivado. Foi constatado também em outras espécies de Erwinia a presença de grupos de plasmídios altamente conservados (Coplin et al., 1981; Falkenstein et al., 1988), os quais podem estar envolvidos com a patogenicidade destas bactérias.

Os resultados obtidos com o perfil plasmidial, da mesma forma que os dados obtidos com marcadores de RAPD mostram que a variabilidade genética nestes isolados de $E$. herbicola é pequena, reforçando a hipótese de que estes isolados bacterianos são endófitos verdadeiros que devem apresentar íntima interação com as plantas hospedeiras, e também com outros microrganismos endofiticos destas plantas.

A presença destas bactérias endofíticas em porta-enxertos de citros, mostra a possibilidade de obter isolados manipulados geneticamente e reintroduzi-los novamente na planta hospedeira, conferindo-lhe novas características. Estas bactérias podem também ser reintroduzidas em plantas axênicas e utilizadas em estudos da interação entre plantas/endófitos. 


\section{CONCLUSÕES}

Com os resultados obtidos pode-se concluir que:

1. Folhas de todos os porta-enxertos de citros analizados, apresentaram alta incidência de bactérias endofíticas, entretanto, estas bactérias não foram encontradas em sementes, sugerindo que não são transmitidas via sementes. Estas bactérias foram divididas em dois grupos principais: endófitas verdadeiras ou obrigatórias, constituído basicamente pela espécie $E$. herbicola,e endófitas facultativas ou epifitas, constituído basicamente por bactérias do gênero Bacillus.

2. A baixa divergência genética, detectada por RAPD e perfil plasmidial entre os isolados de $E$. herbicola, indica que esta variabilidade limitada deve estar associada à especificidade ao habitat. Já em isolados do gênero Bacillus a variabilidade genética detectada por RAPD foi alta, não coincidindo com a análise bioquímica utilizada na identificação destes isolados.

3. Não ocorreu especificidade entre os genótipos bacterianos e os genótipos das plantas hospedeiras analizadas, pois o agrupamento via marcadores de RAPD ocorreu independentemente do porta-enxerto de origem.

4. Os isolados de E. herbicola apresentam íntima associação com o fungo endofítico de citros $G$. citricarpa, o qual estimula o crescimento desta bactéria, por meio da excreção de uma molécula pequena e termoestável, provavelmente um mono ou oligossacarídeo, já os isolados do gênero Bacillus não devem coexistir no interior das plantas com este fungo endofitico, pois estas bactérias são inibidas por metabólitos excretados pelo fungo endofítico. 


\section{REFERÊNCIAS BIBLIOGRÁFICAS.}

- ARAUJO, W.L. \& AZEVEDO, J.L. Isolamento e identificação de microrganismos endofíticos de 11 porta-enxertos de Citrus sp. Anais da $20^{\mathrm{a}}$ Reunião Anual de Genética de Microrganismos, Piracicaba: ESALQ/USP, v.20, p.111, 1995.

- AUFAUVRE-BROWN, A.; COHEN, J.; HOLDEN, D.W. Use randomly amplified polymorphic DNA markers to distinguish isolates of Aspergillus fumigatus. Journal of Clinical Microbiology, v.30, p.2991-2993, 1992.

- BASHAN, Y.; DIAB, S.; OKON, Y. Survival of Xanthomonas campestris pv. vesicatoria in pepper seeds and root in symptomless and dry leaves in non-host plants and in the soil. Plant and Soil, v.68, p.161-170, 1982.

- BICHLER, L.A.; NAGARAJA, K.V.; POMEROY, B.S. Plasmid diversity in Salmonella enteridis of animal, poultry, and human origin. Journal of Food Protection, v.57, p.4-11, 1994.

- BIRNBOIM, H.C.; DOLY, J.. A rapid alkaline extraction procedure for screening recombinant plasmid DNA. Nucleic Acids Research, v.7, p.1513-1523, 1979.

- BRLANSKY, R.H.; TIMMER, L.W.; LEE, R.F. A xylem-limited bacterium detected in sharpshooters and ragweed in blight-affected citru groves. The Citrus Industry, p.40-46, 1984. 
- BODDEY, R.M.; URQUIAGA, S.; REIS, V.; DÖBEREINER, J. Biological nitrogen fixation associated with sugar cane. Plant and Soil, v.137, p.111-117, 1991.

- BRASILEIRO, A.C.M. Biologia de Agrobacterium. ABCTP Notícias, n.20, p.1-6,10, 1993.

-BUGBEE, W.M.; COLE, D.F.; NIELSEN, G. Microflora and invert sugars in juice from healthy tissue of stored sugarbeets. Applied Microbiology, v.29, p.780-781, 1975.

- CABALLERO-MELLADO, J.; MARTINEZ-ROMERO, E.. Limited genetic diversity in the endophytic sugarcane bacterium Acetobacter diazotrophicus. Applied and Environmental Microbiology, v.60, n.5, p.1532-1537, may1994.

- CHANWAY, C.P.; HOLL,F.B.; TURKINGTON, R. Specificity of association between Bacillus isolates and genotypes of Lolium perenne and Trifolium repens from a grass - legume pasture. Canadian Journal of Botany, v.68, p.1126-1130, 1990.

- CHEN, X.; LINE, R.F.; LEUNG, H. Relationship between virulence variation and DNA polymorphism in Puccinia strifformis. Phytopathology, v.83, 1993.

- CHILDS, J.F.L.; KOPP, L.E.; JOHNSON, R.E. A species of Physoderma present in citrus and related species. Phytopathology, v.55, p.681$687,1965$.

- CLAY, K.; MARKS, S.; CHEPLICK, G.P. Effects of insect herbivory and fungal endophyte infection on competitive interactions among grasses. Ecology, v.74, p.1767-1777, 1993.

- COPLIN, D.L. Plasmids and their role in the evolution of plant pathogenic bacteria. Annual Review of Phytopathology, v.27, p.187-212, 1989. 
- COPLIN, D.L.; ROWAN, R.G.;CHISHOLM, D.A.; WHITMOYER, R.E. Characterization of plasmids in Erwinia stewartii. Applied and Environmental Microbiology, v.42, p.599-604, 1981.

- CORREL, J.C.; RHOADS,D.D.; GUERBER, J.C. Examination of mitochondrial DNA restriction fragment length polymorphisms, DNA fingerprints, and randomly amplified polymorphic DNA of Colletotrichum orbiculare. Phytopathology, v.83, p.1199-1204, 1993.

- CROWHURST, R.N.; HAWTHORNE, B.T.; RIKKERINK, E.H.A.; TEMPLETON, M.D. Differentiation of Fusarium solani f. $s p$. cucurbitae races 1 and 2 by random amplification of polymorphic DNA. Current Genetics, v.20, p.391-396, 1991.

- De SAL, G.; MANFIOLETTI, G.; SCHNEIDER, C. A one-tube plasmid DNA mini-preparation suitable for sequencing. Nucleic Acids Research, v.16, p.9878, 1988.

- DÖBEREINER, J. Recent changes in concepts of plant bacteria interactions: endophytic $\mathrm{N}_{2}$ fixing bacteria. Ciência e Cultura, v.44, p.310-313, 1992.

- DONG, Z;; CANNY, M.J.; MCCULLY, M.E.;ROBOREDO, M.R.; CABADILLA, C.F.; ORTEGA, E.; RODES, R. A nitogen-fixing endophyte of sugarcane stems: a new role for the apoplast. Plant Physiology, v.105, p.1139-1147, 1994.

- DUTTA, S.; GIBBS, R.H. Regulation of ethylene biosynthesis in citrus leaves infected with Xanthomonas campestris pv citri. Physiologia Plantarum, v.82, p.225-230, 1991.

- ERDEM, B.; THRELFALL, E.J.; SCHOFIELD, S.L.; WARD, L.R.; ROWE, B. Plasmid profile typing provides a method for the differentiation of strains of Salmonella enteridis phage type 4 isolated in Turkey. Letters in Applied Microbiology, v.19, p.265-267, 1994. 
- FAHEY, J.W. Endophytic bacteria for the delivery of agrochemicals to plants. In: CUTLER, H.O. ed. Biologically Active Natural Products. Potential Use in Agriculture. Washington, American Chemical Society Symposium Ser. 380, 1988, p.120-128.

- FALKENSTEIN, H.; BELLEMANN, P.; WALTER, S.; ZELLER, W.; GEIDER, K.. Identification of Enwinia amylovora, the fireblight pathogen, by colony hibridization with DNA from plasmid pEA29. Applied and Environmental Microbiology, v.54, p.2798-2802, 1988.

- FARBER, J.M.; ADDISON, C.J. RAPD typing for distinguishing species and strains in the genus Listeria. Journal of Applied Bacteriology, v.77, p.242-250, 1994

- FERREIRA, M.E.; GRATTAPAGLIA, D. Introdução ao uso de marcadores RAPD e RFLP em análise genética. Brasilia: EMBRAPA/CENARGEN, 1995, 219p.

- FISHER, P.J.; GRAF. F.; PETRINI, L.E.; SUTTON, B.C.;WOOKEY, P.A. Fungal endophytes of Dryas octopetala from a high artic polar semidesert and from the Swiss alps. Mycologia, v.87, p.319-323, 1995.

- FISHER, P.J.; PETRINI, O.; SCOTT, H.M.L. The distribution of some fungal and bacterial endophytes in maize (Zea mays L.). New Phytologist, v.122, p.299-305, 1992.

- GLIENKE, C. Variabilidade genética no fungo endófito Guignardia citricarpa Kiely detectada por RAPD. Curitiba, 1995, 115p. Diss. (Mestrado) - Universidade Federal do Paraná.

- GREWAL, S.K.; GREWAL, P.S.; GAUGLER, R. Endophytes of fescue grasses enhance susceptibility of Popillia japonica larvae to an entomopathogenic nematode. Entomologia Experimentalis et Applicata, v.74, p.219-224, 1995. 
- GRODZICKER, T.; WILLIAMS, J.; SHARP, P.; SAMBROOK, J. Physical mapping of temperature-sensitive mutations of adenoviruses. Cold Spring Harbor Symposia Quantitative Biology, v.39, p.439-446, 1974.

-HALLMANN, J.; SIKORA, R.A. Toxicity of fungal endophyte secondary metabolites to plant parasitic nematodes and soil-borne plant pathogenic fungi. European Journal of Plant Pathology, v.102, p.155-162, 1996.

- HAYDEN, H.L.; PEGG, K.G.; AITKEN, E.A.B.; IRWIN, J.A.G. Genetic relationships as assessed by molecular markers and crossinfections among strains of Colletotrichum gloeosporioides. Australian Journal of Botany, v.42, p.9-18, 1994.

- HENSON, J.M., FRENCH, R. The polymerase chain reaction and plant disease diagnosis. Annual Review of Phytophatology, v.31, p.81109, 1993.

- HOPKINS, D.L. Xylella fastidiosa: xylem-limited bacterial pathogen of plants. Annual Review of Phytopathology, v.27, p.271-290, 1989.

- HOWARD, M.D.; MUNTIFERING, R.B.; BRADLEY, N.W.; MITCHELL Jr., G.E.; LOWRY, S.R. Voluntary intake and ingestive behavior of steers grazing johnstone or endophyte-infected kentucky-31 tall fescue. Journal of Animal Science, v.70, p.1227-1237, 1992.

- JACOBS, M.J.; BUGBEE, W.M.; GABRIELSON, D.A. Enumeration, location, and characterization of endophytic bacteria within sugar beet roots. Canadian Journal of Botany, v.63, p.1262-1265, 1985.

- JAMES, E.K.; REIS, V.M.; OLIVARES, F.L.; BALDANI, J.I.; DÖBEREINER,J. Infection of sugar cane by the nitrogen-fixing bacterium Acetobacter diazotrophicus. Journal of Experimental Botany, v.45, p.757-766, 1994. 
- JOHNSON, J.A.; WHITNEY, N.J. Citotoxicity and inseticidal activity of endophytic fungi from black spruce (Picea mariana) needles. Canadian Journal of Microbiology, v.40, p.24-27, 1994.

- KADO, C.I.; LIU, S.-T.. Rapid procedure for detection and isolation of large and small plasmids. Journal of Bacteriology, v.145, p.13651373, 1981.

- KNOCH, T.R.; FAETH, S.H.; ARNOTT, D.L. Endophytic fungi alter foraging and dispersal by desert seed-harvesting ants. Oecologia, v.95, p.470-473, 1993.

- LEITE, R.P. Citrus canker. Prevention and control in the State of Parana. Circular do Instituto Agronômico do Paraná, n. 61, 51p., 1990.

- LEITE, R.P.; MOHAN, S.K. Integrated management of the citrus bacterial canker disease caused by Xanthomonas campestris pv. citri in the State of Parana-Brasil. Crop Protection, v.9, p.3-7, 1990.

- LIANG, L.Z.; SOBICZEWSKI, P.; PATERSON, J.M.; JONES, A.L. Variation in virulence, plasmid content, and genes for coronatine synthesis between Pseudomonas syringae pv. morsprunorum and P. s. syringae from Prunus. Plant Disease, v.78, p.389-392, 1994.

- LOUREIRO, M.F. Caracterização das estirpes por técnicas moleculares: o uso dos métodos de PCR e RAPD. In: HUNGRIA, M. \& ARAUJO, R.S. Manual de Métodos Empregados em Estudos de Microbiologia Agrícola, EMBRAPA, Brasília, 1994, p.183-199.

- SAMBROOK, J.; FRITSCH, E.F.; MANIATIS, T. Molecular cloning - A laboratory manual. Cold Spring Harbor Laboratory, Second edition, New York, 1989. 545 p. 
- MANULIS, S.; KOGAN, N.; REUVEN, M.; BEN-YEPHET, Y.. Use of the RAPD Technique for identification of Fusarium oxysporum f. sp. dianthi from carnation. Phytopathology, v.84, p.98-101, 1994.

- MARTIN-KEARLEY, J.; GOW, J.A.; PÉLOQUIN, M.; GREER, C.W. Numerical analysis and the application of random amplified polymorphic DNA polymerase chain reaction to the differentiation of Vibrio strains from a seasonally cold ocean. Canadian Journal of Microbiology, v.40, p.446-455, 1994.

- MEGNEGNEAU, P.; DEBETS, F.; HOECKSTRA, R.F. Genetic variability and relatedness in the complex group of black Aspergilli based on random amplification of polymorphic DNA. Current Genetic, v.23, p.323-329, 1993.

- MENELEY, J.C.; STANGHELLINI M.E. Establishment of inactive population of Enwinia carotovora in healthy cucumber fruit. Phytopathology, v. 65, p.670-673, 1975.

- MISAGHI, I.J.; DONNDELINGER, C.R. Endophytic bacteria in symptomfree cotton plants. Phytopathology, v.80, p.808-811, 1990.

- MOËNNE-LOCCOZ, Y.; SEN, D.; KRAUSE, E.S.; WEAVER, R.W. Plasmid profiles of Rhizobia used in inoculants and isolated from clover fields. Agronomy Journal, v.86, p.117-121, 1994.

- MULLIS, K.; FALOONA, F. Specific synthesis of DNA in vitro via a polymerase catalysed chain reaction. Methods in Enzimology, v.55, p.335-350, 1987.

- MURRAY, F.R.; LATCH, G.C.M.; SCOTT, D.B. Surrogate transformation of perennial ryegrass, Lolium perenne, using genetically modified Acremonium endophyte. Molecular General Genetics, v. 233, p.1-9, 1992. 
- NAMEKATA, T. O cancro cítrico. In: RODRIGUES, O.; VIÉGAS, F.; POMPEU Jr., J.; AMARO, A.A. Citricultura brasileira. 2_. edição. Campinas: Fundação Cargill, 1991. vol.2, p.775-786

- NAMBIAR, P.T.C.; MA, S.-W.; IYER, V.N. Limiting an insect infestation of nitrogen-fixing root nodules of the Pigeon pea (Cajanus cajan) by engeenering the expression of an entomocidal gene in its root nodules. Applied Environmental Microbiology, v.56, p.2866-2869, 1990.

- NICHOLSON, P.; REZANOOR, H.N., SU, H. Use of random amplified polymorphic DNA (RAPD) analysis and genetic fingerprinting to differentiate isolates of race $\mathrm{O}, \mathrm{C}$ and $\mathrm{T}$ of Bipolaris maydis. Journal of Phytopathology, v.139, p.261-267, 1993.

- OUELLET, T.; SEIFERT, K. Genetic characterization of Fusarim graminearum strains using RAPD and PCR amplification. Phytopathology, v.83, p.1003-1007, 1993.

- PANOPOULOS, N.J.; PEET, R.C. The molecular genetics of plant pathogenic bacteria and their plasmids. Annual Review of Phytopathology, v.23, p.381-419, 1985.

- PAULA, M.A.; REIS, V.M.; DÖBEREINER, J. Interactions of Glomus clarum with Acetobacter diazotrophicus in infection of sweet potato (Ipomoea batatas), sugar cane (Saccharum spp.) and sweet sorghum (Sorghum bicolor). Biology and Fertility of Soils, v.11, p.111-115, 1991.

- PEREIRA, J.O.; AZEVEDO, J.L.; PETRINI,O. Endophytic fungi of Stylosanthes: a first report. Mycologia, v.85, p.362-364, 1993,

- PETRINI, O. Taxonomy of endophytic fungi of aerial plant tissues. In: FOKKEMA, N.J. \& HEAVEL, J. Van den, eds. Microbiology of Phyllosphere. London: Cambridge University Press, 1986, p.175187. 
- PETRINI, O. Fungal endophyte of tree leaves. In: ANDREWS, J. \& HIRANO, S.S. eds. Microbial ecology of leaves. New York: Spring-Verlag, 1991, p.179-197.

- PLUMMER, K.M.; DUNSE, K.; HOWLETT, B.J. Non aggressive strains or the blackleg fungus, Leptosphaeria maculans, are present in Australia and can be distinguished from aggressive strains by molecular analysis. Australian Journal of Botany, v.42, p.1-8, 1994.

- RANTA,H.; NEUVONEN,S.; KÄÄRIÄINEN,S.; VESANTO,S. Cooper and nickel pollution: frequency of endophytic fungi in Scots pine shoots an endophyte growth in vitro. Canadian Journal of Botany, v.72, p.93-99, 1994.

- REIS, V.M.; OLIVARES, F.L.; DÖBEREINER, J. Improved methodology for isolation of Acetobacter diazotrophicus and confirmation of its endophytic habitat. World Journal of Microbiology \& Biotechnology, v.10, p.401-405, 1994.

- ROSSETTI, V. Clorose variegada dos citros (CVC). In: RODRIGUES, O.; VIÉGAS, F.; POMPEU Jr., J.; AMARO, A.A. Citricultura brasileira. 2_. edição. Campinas: Fundação Cargill, 1991. vol.2, p.715-721.

- ROSSETTI, V.; GARNIER, M.; BOVÉ, J.M.; BERETTA, M.J.G.; TEIXEIRA, A.R.R.; QUAGGIO, J.A.; DE NEGRI, J.D. Présence de bactéries dans le xyleme d'orangers atteints de chlorose variégée, une nouvelle maladie des agrumes au Brésil. Comptes Rencues Academy and Science, v.310, p.345-349, 1990.

- RUPPEL, S.; HECHT-BUCHHOLZ, C.; REMUS, R.; ORTMANN, U.; SCHMELZER, R. Settlement of the diazotrophic, phytoeffective bacterial strain Pantoea agglomerans on and within winter wheat: an 
investigation using ELISA and transmission electron microscopy. Plant and Soil, v.145, p.261-273, 1992.

- SAIKI, R.K.; GELFAND, D.H.; STOEFFEL, S.; SHCARF, S.J.; HIGUCHI, G.; HORN, G.T.; MULLIS, K.B.; ERLICH, H.A. Primer directed enzymatic amplification of DNA with a thermostable DNA polymerase. Science, v.239, p.487-491, 1988.

- SAMISH, Z.; ETINGER-RULCZYNSKA, R.; BECK, M. The microflora within the tissue of fruits and vegetables. Journal of Food Science, v.28, p.259-266, 1963.

- SANDERY, M.; COBLE, J.; McKERSIE-DONNELLEY, S. Random amplified polymorphic DNA (RAPD) profiling of Legionella pneumophila. Letters in Applied Microbiology, v.19, p.184-187, 1994.

- SANFORD, B.B. The ocorrence of bacteria in normal potato plants and legumes. Scientia Agricol., v.28, p.21-25, 1948.

- SHULZ, B.; WANKE, U.; DRAEGER, S.; AUSTH.J. Endophytes from herbaceous plants and shrubs: effectiveness of surface sterilization methods. Mycological Research, v.97, v.1447-1450, 1993.

- SINCLAIR, J.B. Latent infection of soybean plants and seeds by fungi. Plant Disease, v.75, p.220-224, 1991.

- SNEATH, P.H.A; MAIR, N.S.; SHARPE, M.E.; HOLT,J.G. eds. Bergey's Manual of Systematic Bacteriology. vol.2, Baltimore: Williams \& Wilkins, 1986.

- SOUZA, A.O. Bactérias endofiticas de milho (Zea mays L.) e sua variabilidade genética analisada por RAPD. Piracicaba, 1996, 88p. Diss. (Mestrado) - Escola Superior de Agricultura "Luiz de Queiroz" Universidade de São Paulo. 
- STEPHAN, R.; SCHRAFT, H.; UNTERMANN, F. Characterization of Bacillus licheniformis with the RAPD technique (randomly amplified polynorphic DNA). Letters in Applied Microbiology, v.18, p.260263, 1994.

- STONE, J. K. Foliar endophytes of Pseudotsuga menziesli (mirb) Franco. Cytology and physiology of the host-endophyte relationship. Eugene. 124p. (PhD). University of Oregon, 1986.

- TESTER, C.F. Influence of a genetically modified endophytic bacterium on composition and decomposition of corn residue. Soil Biology and Biochemistry, v.24, p.1107-1112, 1992.

- TOLEDO, M.R.F.; FONTES, C.F.; TRABULSI, L.R. EPM-Modificação do meio de Rugai e Araujo para a realização simultânea dos testes de produção de gás a partir da glicose, $\mathrm{H}_{2} \mathrm{~S}$, urease e triptofano desaminase. Revista de Microbiologia, v.13, p.309-315, 1982.

- TÖR, M.; MANTELL, S.H.; AINSWORTH, C. Endophytic bacteria expressing $\beta$-glucuronidase cause false positives in transformation of Dioscorea species. Plant Cell Reports, v.11, p.452-456, 1992.

- VASCONCELOS, M.J.V.; MACHADO, M.A.; ALMEIDA, A.M.R.; HENNING, A.A.; BARROS, E.G.; MOREIRA, M.A. Defferentiation of Colletotrichum truncatum isolates by random amplified polymorphic DNA. Fitopatologia Brasileira, v.19, p.520-523, 1994.

- VIRET, O.; PETRINI, O. Colonization of beech leaves (Fagus sylvatica) by the endophyte Discula umbrinella (Teleomorph: Apiognomonia errabunda). Mycological Research, v.98, p.423-432, 1994.

- VÖLKSCH, B.; ULLRICH, M.; FRITSCHE, W. Identification and population dynamics of bacteria in leaf spots of soybean. Microbial Ecology, v.24, p.305-311, 1992. 
- WANG, G.; WHITTAM, T.S.; BERG, C.M. et al. RAPD (arbitrary primer $P C R$ ) is more sensitive than multilocus enzyme electrophoresis for distinguishing related bacterial strains. Nucleic Acids Research, v.21, p.5930-5933, 1993.

- WELSH, J.; McCLELLAND, M. Fingerprinting genome using PCR with arbitrary primers. Nucleic Acids Research, v.19, p.303-306, 1990.

- WIEBE, W.L.; CAMPBELL, R.N. Characterization of Pseudomonas syringae pv. maculicola and comparison with $P$. s. tomato. Plant Disease, v.77, p.414-419, 1993.

- WILLIAMS, J.G.K.; HANAFEY, M.K.; RAFALSKI, J.A. et al. Genetic analysis using random amplified polymorphic DNA markers. Methods in Enzymology, v.218, p.706-740, 1993.

- WILLIAMS, J.G.K.; KUBELIK, A.R.; LIVAK, K.J.; RAFALSKI, J.A.; TINGEY, S.V. DNA polymorphisms amplified by arbitrary primers are useful as genetic markers. Nucleic Acids Research, v.18, p.6531-6535, 1990.

- ZHAO, J.; AOKI, T. Plasmid profile analylis of Pasteurella piscicida and use of a plasmid DNA probe to identify the species. Journal of Aquatic Animal Health, v.4, p.198-202, 1992. 
APÊNDICE 
A.1 - Quadro de ANAVA elaborado a partir dos dados contidos na tabela 4.1. Observar a não significância (ns.)da diferença entre os blocos, entretanto foi significativa ao nivel de $1 \%\left({ }^{\star \star}\right)$ a diferença observada entre os tratamentos.

\begin{tabular}{lcrrr}
\hline \multicolumn{6}{c}{ ANAVA } \\
\hline \multicolumn{1}{c}{ F.V. } & G.L. & \multicolumn{1}{c}{ S.Q. } & \multicolumn{1}{c}{ Q.M. } & \multicolumn{1}{c}{ F. } \\
\hline Blocos & 2 & 60,23 & 30,12 & 0,07 ns. \\
Tratamento & 9 & 27820,59 & 3091,18 & $7,25^{\star *}$ \\
Erro experimental & 18 & 7675,07 & 426,39 & \\
\hline Total & 29 & 35555,89 & & \\
\hline
\end{tabular}

C.V. $=29,62$ 


\begin{tabular}{|c|c|c|c|c|c|c|c|c|c|c|c|c|}
\hline & 05 & 06 & 23 & 24 & 32 & 37 & 45 & 47 & 51 & 04 & 11 & 34 \\
\hline & 1.000 & & & & & & & & & & & \\
\hline & 0.875 & 1.000 & & & & & & & & & & \\
\hline & 0.769 & 0.875 & 1.000 & & & & & & & & & \\
\hline & 0.846 & .808 & 0.846 & .000 & & & & & & & & \\
\hline & 0.769 & 0.875 & 0.917 & 0.846 & 1.000 & & & & & & & \\
\hline & 0.880 & 0.840 & 0.880 & 0.960 & 0.880 & 1.000 & & & & & & \\
\hline & 0.792 & 0.750 & 0.792 & 0.731 & 0.720 & 0.760 & 1.000 & & & & & \\
\hline & 0.792 & 0.826 & 0.792 & 0.800 & 0.75 & 0.8 & 0.818 & 1.000 & & & & \\
\hline & 0.875 & 0.833 & 0.80 & 0.880 & 0.8 & 0.9 & 0.826 & 0.9 & 1.000 & & & \\
\hline & 0.200 & 0.11 & 0.0 & 0.143 & 0.0 & 0. & 0.125 & 0.1 & 0.160 & 1.000 & & \\
\hline & 0.174 & 0.083 & 0.080 & 0.167 & 0.080 & 0.167 & 0.136 & 0.1 & 0.174 & 0.400 & 1.000 & \\
\hline & 0.119 & 0.070 & 0.068 & 0.114 & 0.068 & 0.1 & 0.100 & 0.1 & 0.1 & 0. & .1 & 1.000 \\
\hline & 0.114 & 0.091 & 0.089 & 0.109 & 0.089 & 0.1 & 0.095 & 0.1 & 0.1 & 0. &. & .136 \\
\hline 1 & 0.071 & 0.02 & 0.02 & 0.068 & 0.0 & 0. & 0.0 & 0 . & 0.0 & & 1 & 50 \\
\hline & 0.116 & 0. & 0.0 & 0.1 & 0 . & 0. & 0. & 0 . & 0. & 0. & 0. & 89 \\
\hline & 0.075 & 0. & 0. & $0.0^{\circ}$ & 0. & 0. & 0. & 0 . & 0. & 0. & 0. & 0.128 \\
\hline & 0. & 0. & 0. & 0.093 & 0.047 & 0.095 & $0.0^{\circ}$ & 0.0 & 0.1 & 0. & & 0.179 \\
\hline & 0.081 & 0.026 & 0.026 & 0.077 & 0.026 & 0.079 & 0.057 & 0.0 & 0.0 & 0.0 & 5 & 0.206 \\
\hline & 0.111 & 0.036 & 0.034 & 0.143 & 0.071 & 0.1 & 0.0 & 0.0 & 0.1 & 0. & .2 & 0.148 \\
\hline & 0.097 & 0.03 & 0.0 & 0.7 & 0. & 0. & 0. & 0. & 0 & 0 & 0.1 & 0.250 \\
\hline & 0.129 & 0. & 0. & 0.7 & 0. & 0. & 0. & & & & & 0.333 \\
\hline 15 & 0.091 & 0. & 0. & 0.086 & 0. & 0. & 0. & 0. & 0. & 0 . & 0. & 0.121 \\
\hline & 0.103 & 0. & 0. & 0.098 & 0.0 & 0 & & & 0 & & & \\
\hline & 0.100 & 0.032 & 0.031 & 0. & 0.0 & 0. & 0 . & 0 . & 0.1 & 0. & & 0.214 \\
\hline & 0.107 & 0.036 & 0.036 & 0.103 & 0.036 & 0.107 & 0.074 & 0.0 & & 0.1 & & 0.107 \\
\hline & 0.094 & 0.03 & 0.029 & 0.121 & 0.0 & 0.0 & 0.0 & 0.0 & 0.0 & 0.1 & & 0.200 \\
\hline & 0.125 & 0.06 & 0. & 0.152 & 0.0 & 0.1 & 0.7 & 0. & 0.1 & 0.1 & 0.3 & 0.276 \\
\hline & 0.067 & 0.03 & 0. & 0.097 & 0.0 & 0. & 0. & 0 . & 0. & 0.1 & 0. & 0.100 \\
\hline 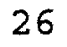 & 0.061 & 0. & 0. & 0.057 & 0.000 & 0.0 & 0.032 & 0. & 0. & $0.1:$ & 0. & 0.161 \\
\hline 28 & 0.121 & 0.059 & 0.05 & 0.114 & 0.057 & 0.118 & 0.0 & 0.0 & 0.1 & 0.167 & 0.2 & 0.267 \\
\hline & 0.097 & 0.031 & 0.030 & 0.125 & 0.030 & 0.094 & 0.069 & 0.0 & 0.1 & 0.200 & 0.2 & 0.207 \\
\hline & 0.086 & 0.028 & 0.02 & 0.111 & 0.027 & 0.083 & 0.0 & 0.0 & 0.0 & 0.100 & 0.1 & 0.182 \\
\hline & 0.083 & 0.027 & 0.0 & 0. & 0.0 & 0.1 & 0.0 & 0.1 & 0.1 & 0.0 & 0.1 & 0.111 \\
\hline & 0.080 & 0.000 & 0.000 & 0.074 & 0.000 & 0.077 & 0.043 & 0.043 & 0.083 & 0.154 & 0.200 & 0.227 \\
\hline
\end{tabular}

A.2 - Matriz de similaridade genética entre os isolados de bactérias endofíticas de porta-enxertos de citros, analisados dois a dois segundo o coeficiente de similaridade de JACCARD. 


\begin{tabular}{|c|c|c|c|c|c|c|c|c|c|c|c|c|}
\hline & 16 & 31 & 25 & 27 & 33 & 17 & 01 & 07 & 08 & 09 & 13 & 14 \\
\hline 16 & 1.000 & & & & & & & & & & & \\
\hline 3 & 0.200 & 1.000 & & & & & & & & & & \\
\hline 25 & 0.109 & 0.205 & 1.000 & & & & & & & & & \\
\hline 27 & 0.095 & 0.077 & 0.154 & 1.000 & & & & & & & & \\
\hline 33 & 0.116 & 0.128 & 0.119 & 0.556 & 1.000 & & & & & & & \\
\hline 17 & 0.194 & 0.444 & 0.135 & 0.121 & 0.147 & 1.000 & & & & & & \\
\hline 01 & 0.031 & 0.1 & 0.185 & 0.08 & 0.1. & 0.143 & 1.000 & & & & & \\
\hline 0 & 0.0 & 0.1 & 0.12 & 0.1 & 0.1 & 0.1 & 0.3 & 1.0 & & & & \\
\hline 08 & 0.056 & 0.172 & 0.121 & 0.103 & 0.133 & 0.160 & 0.462 & 0.533 & 1.0 & & & \\
\hline 09 & 0.114 & 0.094 & 0.118 & 0.138 & 0.094 & 0.154 & 0.111 & 0.091 & 0.087 & 1.000 & & \\
\hline 13 & 0.150 & 0.400 & 0.154 & 0.111 & 0.135 & 0.423 & 0.080 & 0.192 & 0.143 & 0.138 & 1.000 & \\
\hline 14 & 0.059 & 0.143 & 0.094 & 0.154 & 0.103 & 0.125 & 0.308 & 0.5 & 0.5 & 0.0 & 0.1 & 1. \\
\hline 1 & 0.138 & 0.3 & 0.14 & 0. & 0. & 0.4 & 0.1 & 0. & 0 & 0.2 & 0.4 & 0.11 \\
\hline 20 & 0.086 & 0.1 & 0.12 & 0. & 0. & 0. & 0. & 0. & 0. & 0.0 & 0.1 & 0.29 \\
\hline 27 & 0.147 & 0.167 & 0.152 & 0. & 0. & 0. & 0.429 & 0. & 0. & 0.0 & 0.1 & 0.278 \\
\hline 22 & 0.094 & 0.240 & 0.097 & 0.074 & 0.069 & 0.238 & 0.231 & 0.111 & 0.1 & 0.158 & 0.208 & 0.118 \\
\hline 26 & 0.118 & 0.259 & 0.088 & 0.143 & 0.133 & 0.450 & 0.118 & 0.095 & 0.0 & 0.250 & 0.333 & 0.15 \\
\hline 28 & 0.111 & 0.161 & 0.114 & 0.063 & 0.12 & 0.1 & 0.3. & 0.3 & 0.3 & 0.1 & 0.1 & 0.26 \\
\hline 3 & 0.088 & 0.179 & 0.125 & 0.0 & 0.1 & 0.1 & 0.5 & 0.3 & 0.5 & 0.0 & 0.1 & 0.31 \\
\hline & 0.242 & 0.233 & 0.081 & 0.0 & 0.121 & 0.3 & 0.1 & 0.1 & 0.1 & 0.2 & 0.207 & 0.08 \\
\hline & 0.235 & 0.22 & 0.108 & 0.1 & 0.0 & 0.1 & 0.0 & 0.1 & 0.1 & 0.1 & 0.2 & 0.18 \\
\hline- & 0.160 & 0.389 & 0.083 & 0.190 & 0.190 & 0.571 & 0.154 & 0.143 & 0.214 & 0.111 & 0.400 & 0.14 \\
\hline
\end{tabular}

\begin{tabular}{|c|c|c|c|c|c|c|c|c|c|}
\hline & 19 & 20 & 21 & 22 & 26 & 28 & 30 & 38 & 40 \\
\hline & 1.000 & & & & & & & & \\
\hline & 0.211 & 1.000 & & & & & & & \\
\hline & 0.200 & 0.563 & 1.000 & & & & & & \\
\hline & 0.286 & 0.235 & 0.100 & 1.000 & & & & & \\
\hline & 0.438 & 0.143 & 0.136 & 0.400 & 1.000 & & & & \\
\hline & 0.190 & 0.529 & 0.421 & 0.278 & 0.182 & 1.000 & & & \\
\hline & 0.167 & 0.643 & 0.600 & 0.176 & 0.150 & 0.389 & 1.000 & & \\
\hline & 0.250 & 0.125 & 0.120 & 0.263 & 0.421 & 0.115 & 0.130 & 1.000 & \\
\hline & 0.238 & 0.167 & 0.115 & 0.316 & 0.333 & 0.250 & 0.125 & 0.348 & 1.000 \\
\hline & 0.364 & 0.176 & 0.125 & 0.308 & 0.357 & 0.176 & 0.188 & 0.278 & 0.29 \\
\hline
\end{tabular}

A.2 - Continuação. 